\title{
"Tax Avoidance through Controlled Foreign Companies under European Union Law with Specific Reference to Poland"
}

\begin{abstract}
This article demonstrates that tax avoidance via controlled foreign companies (CFCs) established in the most favourable tax environments among EU Member States such as Ireland, Luxembourg, the Netherlands, and Cyprus, remains a considerable problem. Not only does it affect taxpaying residents in the Member States but, indirectly, all taxpayers regardless of their EU affiliation, US multinational enterprises (MNEs), for example. Focusing on the use Polish taxpayers make of CFCs, this study undertakes a detailed legal analysis of the problem of tax avoidance under EU law by examining empirical data and EU law on tax avoidance. The choice of this topic is largely justified by the exponential rise in tax avoidance schemes through CFCs involving Polish taxpayers since the country's accession to the EU. The legal analysis brings to light a series of weaknesses in the current EU law that make it possible for both EU and non-EU taxpayers to avoid taxation. As a solution to this problem, the author suggests that CFC rules should be designed so as to tax only "tax avoidance income" from CFCs. This would ensure their compliance with EU law as well as an effective prevention of tax avoidance via CFCs within the framework of EU law. Interestingly, the solution follows from the author's interpretation of the concept of "wholly artificial arrangements" in favour of the internal market rather than from Action 3 of Base Erosion and Profit Shifting (BEPS) project or Anti-Tax Avoidance Directive as adopted by the Council on 12 July 2016.
\end{abstract}

Keywords: tax avoidance, CFC, EU law, CJEU, OECD, BEPS.

\section{Table of Contents}

Table of Contents 1

Introduction: the Problem of tax avoidance under EU law 4

2 Terminological considerations: General features of CFCs, tax havens, lowtax jurisdictions, and CFC tax avoidance ............................................................................... 7

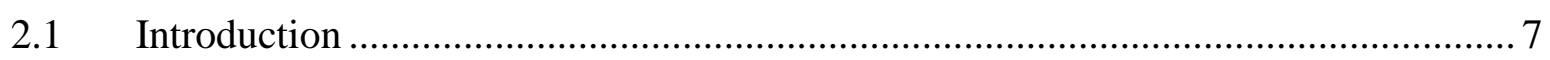

2.2 Controlled Foreign Companies (CFC) ......................................................... 7

2.3 Tax haven and low-tax jurisdiction .................................................................... 8

2.3.1 Tax haven: No or very low effective taxation ......................................... 9

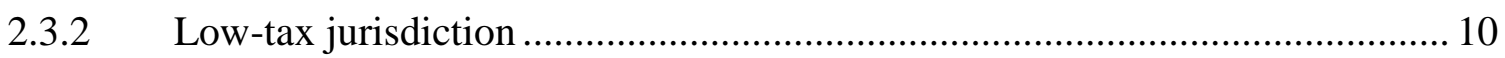


2.4 "CFC tax avoidance"

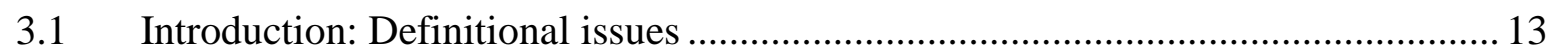

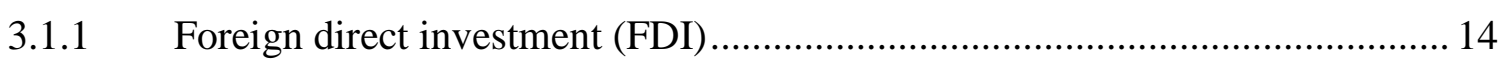

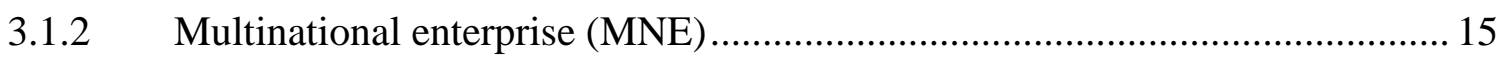

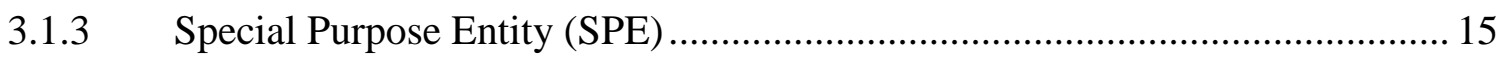

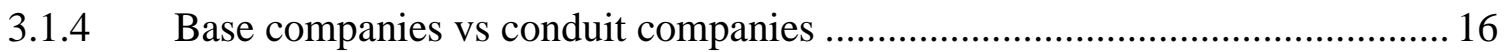

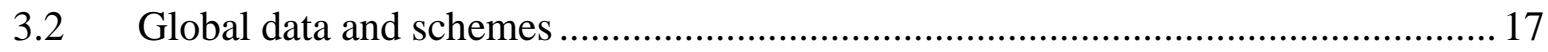

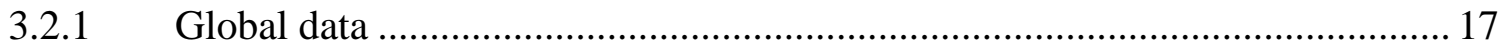

3.2.2 A brief discussion of selected international tax avoidance schemes within the EU 19

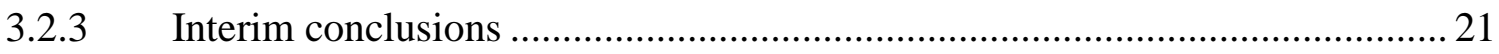

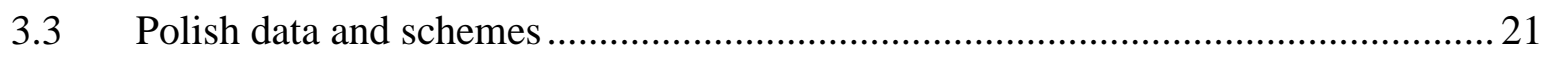

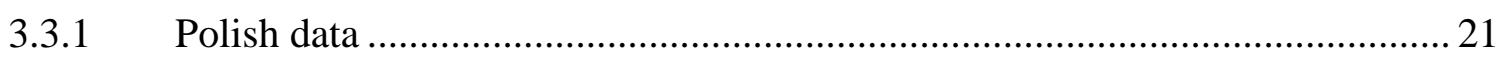

Figure I: The value of outward FDIs of Polish investors 1994-2011 in millions of PLN 24

3.3.2 Selected tax avoidance schemes by Polish taxpayers ................................... 24

Figure II: "Double Cypriot Olive with a Polish Potato": Total tax avoidance of Polish

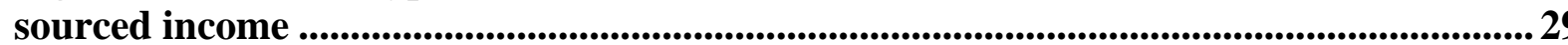

Figure III: "Luxembourg CFC Scheme": total tax avoidance of income generated in

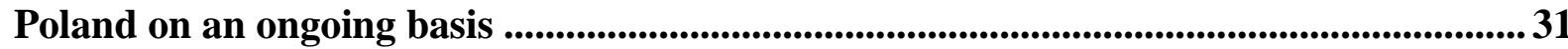

Figure IV: "LPP Scheme": Tax avoidance on income from royalties and director fees.34

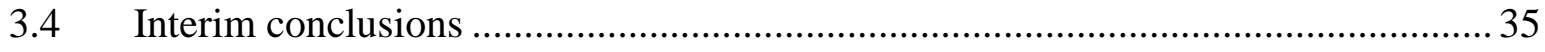

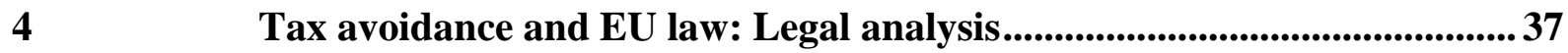

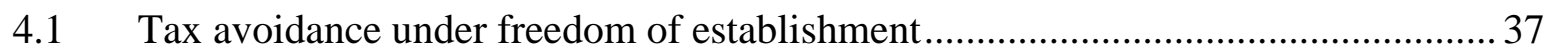

4.1.1 Company law in the case law of the CJEU and its effect on tax avoidance

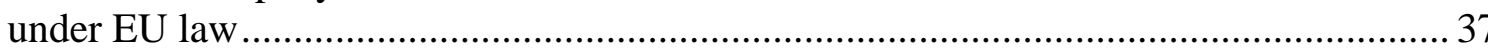

In light of Art. 49 TFEU, CJEU already stated in its judgment in the Centros case that 37

4.1.2 Limited effect of company law case law of CJEU on tax avoidance cases:

"normal" tax avoidance is permissible under EU law, while "qualified" (=wholly artificial) tax avoidance is not

4.2 The concept of abuse of EU law in tax cases: tax avoidance via wholly artificial arrangements

4.3 Purposive interpretation of "wholly artificial arrangements" in favor of the internal market 46

5 Taxation of only "tax avoidance income" under CFC rules as a solution for the problem of CFC tax avoidance within the framework of EU law.

5.1 Preliminary remarks: References to the critical evaluation of the OECD's recommendations (BEPS Action 3) and the EU Council's (Anti-Tax Avoidance Directive) minimum standards 


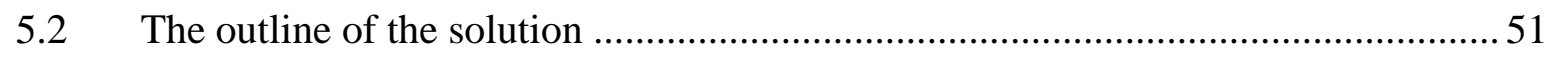

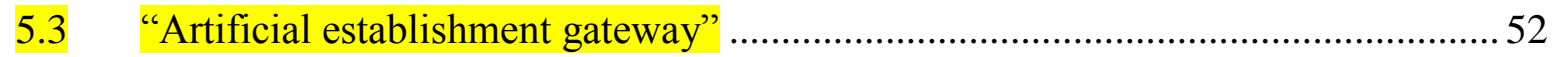

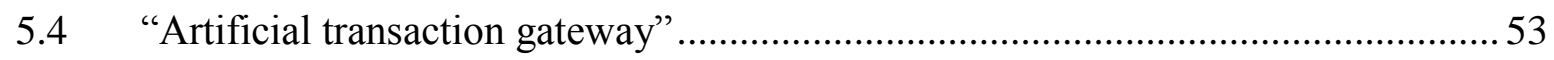

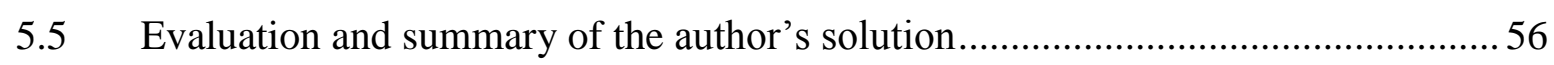

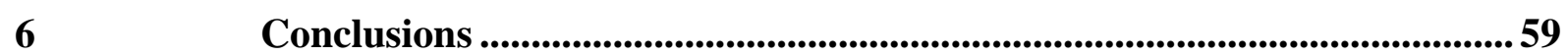

Appendix CFC tax avoidance schemes involving Polish taxpayers.................................... 62

$1 \quad$ Preliminary remarks ........................................................................................6 62

1.1 Netherlands and Curaçao CFCs: long-term tax deferral and reduction of

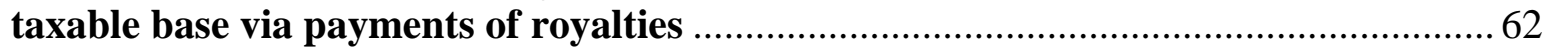

1.2 Maltese CFCs: reduction of effective taxation to 5 percent ............................ 66

Figure VI: CFC scheme with Maltese CFCs: reducing effective tax rate to 5 percent ... 67

1.3 Slovak and Cypriot CFCs: a triangular structure resulting in triple non-

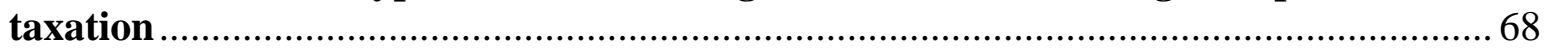

Figure VII: CFC scheme involving Cypriot and Slovak CFC: triple non-taxation of income sourced in Poland .70

1.4 Cypriot CFC: double non-taxation of director fees and unjustified tax sparing clause 70

Figure VIII: CFC scheme involving Cypriot CFC: the application of the unjustified tax

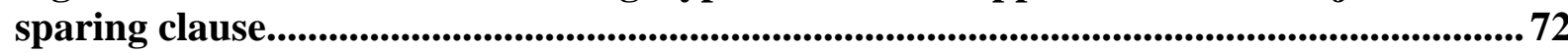

2 Conclusions

References 74

Bibliography 74

Anker-Sørensen, L., (2016), Financial Engineering as an Alternative, Invisible Veil for the 74

Case law and administrative decisions 84

\section{International 84}

EFTA Court 84

CJEU: Court of Justice of the European Union.....................................................................8 84

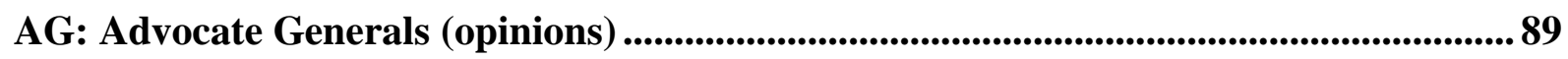

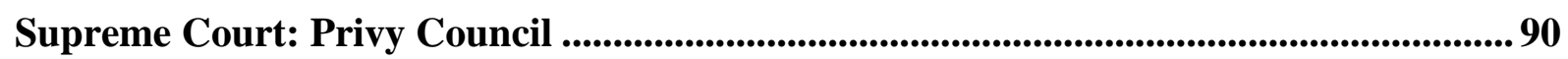

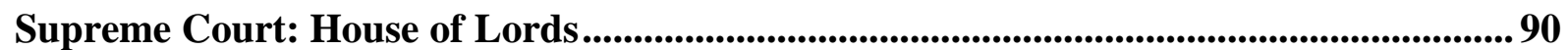

Poland 91

SAC: Supreme Administrative Court (Naczelny Sąd Administracyjny) .......................... 91

DTCh: Director of Tax Chamber (Dyrektor Izby Skarbowej) - advance tax rulings....... 91

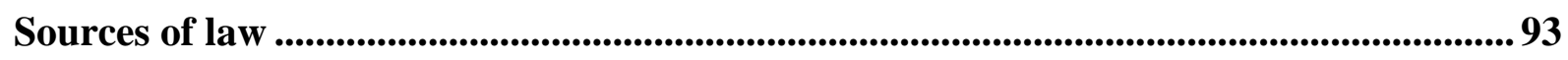

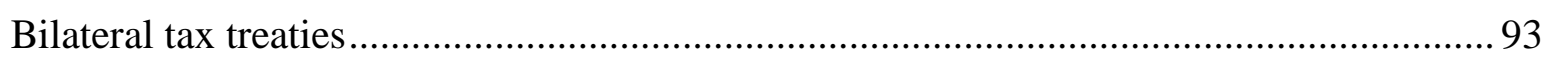

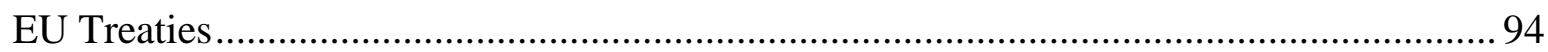

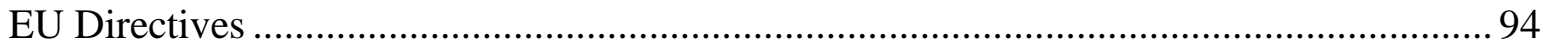


Communication, proposals, resolutions, reports and others

Poland 96

$\begin{array}{cc}\text { Statutes } & 96 \\ \text { Regulations } & 97 \\ \text { UK } \quad 97 & \end{array}$

Statutes $\quad 97$

OECD: Reports and other documents 98

Official documents and hearings 100

Acknowledgments: This study is largely based on parts of chapters 1, 3, and 17 of my $\mathrm{PhD}$ dissertation "Controlled Foreign Companies and Tax Avoidance: International and Comparative Perspectives with Specific Reference to Polish Tax and Constitutional Law, EU Law and Tax Treaties". PhD defense took place on 13 January 2017 at the Department of Public and International Law, Faculty of Law, University of Oslo. The inspiration to write an article based on these parts of my study arose during a $\mathrm{PhD}$ seminar on companies and markets looking at topical issues in EU and Nordic company and financial market law, organized by the Research Group on Companies, Markets, Society and the Environment at the Oslo Faculty of Law, 5-8 October 2015. Professor Yuri Biondi advised me to submit the article for publication to your journal. I would like to thank you him for doing so. I would also like to thank Professor Frederik Zimmer for invaluable comments during the writing of the $\mathrm{PhD}$ study, including the parts I am using for the purpose of this article.

\section{Introduction: the Problem of tax avoidance under EU law}

Freedom of establishment and free movement of capital are of utmost importance for taxpayers avoiding taxation under EU law insofar as they allow them to freely divert income to any Member State or third country respectively. The freedoms are directly available to EU nationals, both individuals and companies, and indirectly to non-EU individuals or companies that established a company under the law of a Member State. ${ }^{1}$ In the latter case, a company resident in a third country, for example US MNE, can establish a subsidiary under the Dutch company law and if this subsidiary has a real and continuous link with the territory of the Netherlands, i.e. it is not a mere registered office without any economic substance and purpose, but has central administration or principal place of business in the Netherlands, then

\footnotetext{
${ }^{1}$ C-212/97, paragraph 19 and C-208/00 paragraphs 74-75.
} 
it benefits from EU law, including primary law (e.g. fundamental freedoms) ${ }^{2}$ and directives (e.g. Parent-Subsidiary Directive ${ }^{3}$ or Interest \& Royalties Directive).${ }^{4}$ Considering that the US MNE wholly owns its Dutch subsidiary, directly or indirectly, the subsidiary is fully controlled by its US parent and therefore it may be used for any purpose, including receiving and transferring income for tax avoidance purposes. It is also noteworthy that the subsidiary will most likely be considered - functionally - a $\mathrm{CFC}^{5}$ of the US MNE (legally speaking this may not be possible under check-the-box rules as applied by the US MNE). ${ }^{6}$

Depending on the transactions involved, the subsidiary (CFC) may be protected by freedom of establishment within the EU or globally by free movement of capital. ${ }^{7}$ Thus, residents of non-Member States are, as a matter of fact, not restricted from benefiting from EU law indirectly. ${ }^{8}$ Their attempts to avoid taxation through the use of CFCs under EU law are not excluded from the scope of these benefits as such. This shows that the EU freedoms may be used by EU and non-EU tax residents to avoid taxation via CFCs established in Member States. The freedoms, however, have a different impact on the tax avoidance practices of EU and non-EU tax residents.

To a large extent, the freedoms protect taxpayers before taxation under the domestic anti-avoidance provisions found in the Member State of their tax residence, such as CFC rules. ${ }^{9}$ The protection follows from the fact that Member States are bound by the concept of the wholly artificial arrangement developed by the Court of Justice of the European Union (CJEU), which significantly restricts the application of their CFC rules. ${ }^{10}$ By contrast, legally speaking, non-Member States are not bound by this impediment. Tax avoidance by EU tax residents may therefore be less effectively prevented than tax avoidance by non-EU tax residents due to the effect of EU law. ${ }^{11}$ Now this suggests that currently the EU law still seems to facilitate tax avoidance both for EU and non-EU taxpayers instead of curbing this phenomenon, with a bias in favor of EU taxpayers.

\footnotetext{
${ }^{2}$ Art. 28 (free movement of goods), Art. 45 (free movement of employees), Art. 49 (freedom of establishment), Art. 56 (free movement of services), and Art. 63 (free movement of capital) Treaty on the Functioning of the European Union (TFEU).

${ }^{3}$ Parent-Subsidiary Directive (2011/96).

${ }^{4}$ Interest \& Royalties Directive (2003/49).

${ }^{5}$ See infra 2.2.

${ }^{6}$ Cf. Fuest et al. (2013), pp. 310-312; Avi-Yonah (2007), pp. 35-37, 132 and 135; Avi-Yonah (2015), p. 42.

${ }^{7}$ See Art. 63(1) TFEU. However, the free movement of capital between member states and third countries is subject to several limitations; the most important of them is the so-called standstill clause included in Art. 64(1) TFEU. See also the limitation under Art. 65 TFEU.

${ }^{8}$ Cf. O'Shea (2007), p. 373.

${ }^{9}$ C-196/04, paragraph 51.

${ }^{10}$ See infra section 3.

${ }^{11}$ Cf. OECD (2015), paragraph 19.
} 
Such a state of affairs is unacceptable if one takes into consideration that tax avoidance via CFCs may seriously distort optimal allocation of resources within the EU by jeopardizing "balanced allocation between Member States of the power to impose taxes". ${ }^{12}$ This, in turn, may distort the establishment of an internal market, ${ }^{13}$ which constitutes one of the most important purposes of the functioning of the EU. ${ }^{14}$ Hence, Member States should be rather encouraged by EU law to implement and apply effective CFC rules rather than the opposite.

This study aims to verify whether the use of EU law by taxpayers may result in flourishing tax avoidance. The attention is given to tax avoidance with the use of CFC, since this is one of the most frequently used means of avoiding taxation by taxpayers. ${ }^{15}$ The objective of the study, in addition to the introduction, will be achieved by pursuing the analysis along three main parts of the article, 2-5, followed by the conclusions in part 6. Part 2 provides terminological considerations regarding CFCs, tax havens, low-tax jurisdictions, and CFC tax avoidance. Part 3 focuses on empirical data and schemes ${ }^{16}$ concerning CFC tax avoidance globally and in Poland. Part 4 includes legal analysis of tax avoidance under EU law. Part 5 provides my solution to effective and EU law-compatible prevention of CFC tax avoidance within the legal framework of EU law. Corresponding conclusions will follow in Part 6.

The issues to be discussed in this study include, among others, economic data that highlight the large-scale tax avoidance practices of Polish taxpayers, as well as a detailed discussion of the examples of three blatant tax avoidance schemes used by Polish taxpayers. However, these are of global relevance, and do not concern Poland only. Taking Poland as a case study to the mentioned extent is of a special interest for an international audience, especially on account of the dearth of knowledge in the US and other Western Countries about the countries of Central and Eastern Europe (as Poland) where legislatures have had to reconstruct their legal systems after the collapse of the Soviet system (Poland was not part of the Soviet Union, but was under its influence). ${ }^{17}$ Moreover, the analysis of Poland will show how tax avoidance can increase dramatically when countries become member of the EU.

\footnotetext{
${ }^{12}$ See C-196/04, paragraph 56 and C-446/03, paragraph 46. Cf. more generally negative impact of tax avoidance.

${ }^{13}$ Cf. Schön (2008), p. 82. Concurring: Karimeri (2011), p. 314.

${ }^{14}$ Art. 3(3) Treaty on European Union (TEU) says that the Union shall establish an internal market. See also Kemmeren (2008), pp. 559 and 585; Cordevener (2006), pp. 4-6, 39 and 43.

${ }^{15}$ See OECD (2013), p. 40 and OECD (2015), p. 9.

${ }^{16}$ Three selected Polish tax avoidance schemes will be presented and analysed in details (remaining schemes are described in Appendix).

${ }^{17}$ Cf. Zweigert and Kötz (1998), p. 17. More precisely, Poland has been classified for comparative tax law purposes to a post-conflict area, see Thuronyi (2003), pp. 33-37 and 43.
} 
Beyond that, the discussion is of global focus and relevance, because every taxpayer, regardless of its tax residence within or outside the EU, may practically speaking use the EU law for their tax avoidance purposes.

\section{Terminological considerations: General features of CFCs, tax havens, low-tax jurisdictions, and CFC tax avoidance}

\subsection{Introduction}

Four terms will be used throughout the study from a global perspective: CFC, tax haven, lowtax jurisdiction, and tax avoidance via CFCs (CFC tax avoidance). Recognizing their general, functional features may be useful for the analysis of the influence of the EU law on tax avoidance practices. In the following, I will explain some of the most important functional features as recognized by governments and international organizations.

\subsection{Controlled Foreign Companies (CFC)}

A CFC can generally be described in terms of its main function: tax avoidance. This takes place (i) either in the form of extensive tax deferrals in the countries where the CFCs are located, in the context of a worldwide taxation system (e.g. US); or (ii) in the form of total tax avoidance or reduced effective tax rates from the perspective of the country where the CFC is located, in the context of a territorial taxation system (e.g. France), or of worldwide exemptions for foreign-sourced income based on tax treaties and/or the Parent-Subsidiary Directive (e.g. Poland) ${ }^{18}$ In this regard, some general features can help identify the CFCs that are enacted and implemented by most of the countries in which CFC rules are in force. ${ }^{19}$

First, a CFC must ideally be controlled by one or more participants, who can make financial policy decisions. So as a starting point, a CFC is any foreign entity that is controlled by one or more tax residents of a country applying CFC rules; these are defined as the CFC's participant(s).

Second, tax avoidance via foreign entities is most likely ${ }^{20}$ to be effective if the income of these entities is taxed at a lower level in their country of residence than the income of their participants in the participants' country of residence. ${ }^{21}$

\footnotetext{
${ }^{18}$ Cf. Blanchard (2015).

${ }^{19}$ See Dahlberg and Wiman (2013), pp. 29-40.

${ }^{20}$ I say "most likely", because even if the CFC's were to be taxed at a higher level than in the country of its participants, the CFC's or its income may get "hybrid" treatment and therefore neither be taxed in its residence state nor in the state of its participants.
} 
Third, tax avoidance is possible if a foreign entity's income is not taxed directly at the level of its participants; therefore such entities must be seen as separate taxable entities under the tax law of the participants' state. This means that typically a CFC can be a non-resident (foreign) taxable company but may not be a foreign branch or tax transparent partnership because the latter, as a rule, is not treated as a separate taxable entity and its income is taxed directly at the level of its participants (head office/partners). ${ }^{22}$ In practice, however, it will often make sense to view foreign PE and hybrid entities as CFCs if, like typical CFCs, they are used for tax avoidance purposes. ${ }^{23}$

\subsection{Tax haven and low-tax jurisdiction}

The opportunities for CFCs' participants to avoid taxation multiply when the CFCs are located in jurisdictions where the effective taxation of the income of companies or other entities is either low or non-existent. ${ }^{24}$ Determining the status of a jurisdiction for the purpose of applying CFC rules will therefore require an evaluation of the jurisdiction's effectiveness in preventing CFC tax avoidance.

There are, however, differences in this regard. While most states have different criteria and thresholds for what they consider low-tax jurisdictions and tax havens, ${ }^{25}$ some of them have no low-tax criterion at all, for example Canada, ${ }^{26}$ New Zealand, ${ }^{27}$ Indonesia ${ }^{28}$ and Denmark. ${ }^{29}$ Although the US and the UK are in this group, US CFC rules exclude the CFC's income from taxation (foreign-based company income other than oil-related income) if it is subject to a high effective tax rate, i.e., exceeds 90 per cent of the maximum US corporate income tax rate; ${ }^{30}$ and UK CFC rules exempt from taxation a CFC's income that is taxed by at least 75 per cent of the amount of the tax on corporate income in the UK. ${ }^{31}$ These differences in the various approaches to tax havens and low-tax jurisdictions reflect the different interests at stake and the differences in the systems of taxation of the states applying CFC rules.

\footnotetext{
${ }^{21}$ See, however, Blanchard (2015). See also infra 1.6.2.

${ }^{22}$ See Arnold and Dibout (2001), pp. 40-41. Arnold and Dibout (2001), pp. 40-41; Thill and Mihac (1999), p. 779; OECD (2015a), paragraphs 24 and 71.

${ }^{23} \mathrm{Id}$.

${ }^{24}$ Cf. OECD (2015a), paragraph 61; Arnold and Dibout (2001), p. 45.

${ }^{25}$ See Dahlberg and Wiman (2013), pp. 36-38.

${ }^{26}$ See Slaats and Worndl (2013), p. 190.

${ }^{27}$ See McCulloch and Redington (2013), p. 535.

${ }^{28}$ See Umar (2015a), p. 88.

${ }^{29}$ See Koerver Schmidt (2013), p. 269.

${ }^{30}$ See Rienstra (2015), p. 211.

${ }^{31}$ See Anderson and Jupp (2013), p. 769.
} 


\title{
2.3.1 Tax haven: No or very low effective taxation
}

The broadest definition of a tax haven is any jurisdiction whose tax laws interact with those of another enabling the avoidance of taxation in that other jurisdiction. ${ }^{32}$ Thus, one could say, a tax haven is relative as every jurisdiction can be a tax haven in relation to another: "a tax haven is like beauty in the eye of the beholder." ${ }^{33}$ Even countries practising a 35 per cent corporate income tax (CIT) rate, such as Malta, may be considered "tax havens" from the Polish perspective, where the CIT rate is 19 per cent. It follows from the fact that a Polish taxpayer participating in the profits of the Maltese company is entitled to receive a refund of six-sevenths or even all of the tax paid by this company. ${ }^{34}$ As a result, the effective tax rate of the income generated by the Maltese company and received by the Polish taxpayer will amount to 5 per cent or less. ${ }^{35}$

However, as Brian Arnold put it with respect to tax havens,

\begin{abstract}
Any attempt to measure the relative tax burdens in various countries is extremely difficult and must take into account not only income taxes and corporation taxes, but also commodity, payroll, and other indirect taxes and the value of government services and benefits. Inevitably, judgments about relative tax burdens are very rough. ${ }^{36}$
\end{abstract}

Given the difficulties in defining a "tax haven" from a relative perspective, it may be impossible to provide a general and objective definition. Instead, the perspective of every country should be evaluated on a separate basis and in light of the particular circumstances of relevance to taxation. This study does not ignore "high tax" jurisdictions insofar as they may be used for tax avoidance purposes.

Nevertheless, for the sake of simplicity and in order to highlight certain important matters discussed in the study, the term "tax haven" will be considered as a jurisdiction with no or very low effective taxation on all types of income or on such income as may be easily diverted to a CFC established in such a jurisdiction. This is also commensurate with the old nomenclature of the OECD regarding "classical tax haven". ${ }^{37}$

As far as I am aware, the OECD does not take the no or very low-taxation criterion into account when defining tax havens insofar as the effective exchange of tax information

\footnotetext{
${ }^{32}$ See OECD (1987), paragraph 2; OECD (1998),paragraph 26. Cf. Piccioto (1992), p. 132; Arnold (1986), p. 114.

${ }^{33}$ See Orlov (2004), p. 109.

${ }^{34}$ See Torregiani (2015), pp. 53-54.

${ }^{35} \mathrm{Id}$.

${ }^{36}$ See Arnold (1986), p. 114.

${ }^{37}$ See OECD (1987), paragraph 10 and OECD (1998),paragraphs 42-44.
} 
and transparency are the only things that matter in this connection. ${ }^{38}$ The point is, however, that this study focuses on tax avoidance, not tax evasion, and for tax avoidance purposes the main criterion is no or very low-taxation, while for tax evasion it is the lack of exchange of tax information.

Further, jurisdictions that do not tax income at all or only marginally tend to avoid exchanging tax information and information on the clients of their banks and the participants of entities established on their territories. ${ }^{39}$ So while the lack of an effective means of tax information exchange and transparency matters primarily for tax evasion, not tax avoidance, excluding these definitional factors in this study does not mean that tax havens as defined here would not correspond with the definition of a tax haven under the current international standards. ${ }^{40}$

\subsubsection{Low-tax jurisdiction}

The meaning of "low-tax jurisdiction" is concisely determined as a jurisdiction that (i) has low effective taxation on all types of income or on such income as may be easily diverted to a CFC established in such jurisdiction; and (ii) is engaged in the exchange of tax information under a relevant international agreement. The existence of the second factor entails a distinction between "low-tax jurisdiction" and "tax haven" under the current OECD nomenclature and a partial distinction between the two in the present study. ${ }^{41}$

Low effective taxation is relative and the threshold below which a jurisdiction may be seen as a "low-tax jurisdiction" is usually given as a certain percentage of corresponding effective taxation in a state applying CFC rules. For example, in France ${ }^{42}$ and Italy $^{43}$ the threshold is less than 50 per cent; in Portugal less than 60 per cent; ${ }^{44}$ in Sweden less than 55 per cent ${ }^{45}$ in Norway less than about 66.6 per cent $;{ }^{46}$ less than 75 per cent in Mexico, ${ }^{47}$ Spain, ${ }^{48}$ South Africa, ${ }^{49}$ the UK ${ }^{50}$ and Poland $;{ }^{51}$ and finally less than 90 per cent in the US. ${ }^{52}$

\footnotetext{
${ }^{38}$ Since 2001, the OECD has officially used transparency and effective exchange of information as the only criteria for identifying jurisdictions as uncooperative tax havens. See OECD (2001a), paragraph 28 and most recently OECD (2014c), pp. 26 et seq. Cf. Orlov (2004), pp. 95-111.

${ }^{39}$ See Booijink and Weyzig (2007), p. 1.

${ }^{40}$ See more about historical interrelations between tax havens and CFC tax avoidance in Piccioto (1992), p. 150.

${ }^{41}$ See supra 2.3.1.

${ }^{42}$ See Jacquot (2013), p. 309.

${ }^{43}$ See Avella (2013), p. 413.

${ }^{44}$ See Loureiro and Rodrigues (2013), p. 609.

${ }^{45}$ See Gerson (2013), p. 713.

${ }^{46}$ See Svensen (2013), p. 554.

${ }^{47}$ See Pizarro-Suárez and Revilla Martínez (2013), p. 483

${ }^{48}$ See Báez and Zornoza (2013), p. 690.

${ }^{49}$ See Tickle (2013), p. 674.
} 


\section{4 "CFC tax avoidance"}

Likewise, in the case of tax havens it is almost impossible to define tax avoidance, since it is relative and depends on the extent to which legislators, courts, and tax authorities of various states tolerate the behaviour of a taxpayer leading to a reduction of their tax liability. Such tolerance will obviously be lower in high tax jurisdictions with transparent and robust tax systems, such as Norway, than in preferential and low-tax jurisdictions, such as Cyprus, Luxembourg, or Ireland, and almost unlimited in tax havens. In the same vein, the taxpayers who face high tax burdens and their tax advisors will typically perceive attempts to reduce their tax liabilities as acceptable features of tax planning, while tax authorities will normally be reluctant to do so, except tax authorities in tax havens. Therefore, I shall not give an exact definition of "tax avoidance"; and the different types of transaction, scheme, and label relating to taxpayers' actions to reduce their tax liability will simply be identified in the study as "CFC tax avoidance" measures.

Generally speaking, the term tax avoidance used in the study may be identified with terms such as "aggressive tax planning",53 "impermissible or abusive tax avoidance",54 "unacceptable tax avoidance", 55 "tax abusive shelters", 56 "circumvention of tax law", 57 etc. It refers to actions by taxpayers that are usually not penalized by criminal law ${ }^{58}$ but have two cumulative elements: (i) taxpayers formally comply with the letter of tax law and submit requisite information to tax authorities to determine their tax liability; (ii) but their actions lack a valid economic purpose, apart from obtaining tax benefits typically by deferring

\footnotetext{
${ }^{50}$ See Anderson and Jupp (2013), p. 769.

${ }^{51}$ See $24 \mathrm{a}(3)$ point 3 letter c) CITA and Article 30f(3) point 3 letter c) PITA.

${ }^{52}$ See Rienstra (2015), p. 211.

${ }^{53}$ See OECD, (2013a), p. 37 and in Australia ATO (2005).

${ }^{54}$ In South Africa see SARS (2005).

${ }^{55}$ In New Zealand and the UK see Lord Templeman's statement in the CIR (NZ) $v$ Challenge Corporation Ltd and the Lord Goff's statement in the Ensign Tankers (Leasing Ltd) v Stokes). See more Templeman (1997). ${ }^{56}$ IRS (2015).

57 See in Poland SAC's judgment of 10 November 1994. See in literature Zalewski, (1998), p. 7; Brzeziński and Kalinowski, (1993), pp. 479 et seq.).

${ }^{58}$ But even this depends on domestic law inasmuch as tax avoidance may be punishable in some countries, see Zimmer (2002), pp. 54-55. The legality of tax avoidance distinguishes it from tax evasion, which is an illegal way of reducing tax burdens by concealing sources of income or by falsifying documents necessary to calculate the tax by taxpayers. See more on distinguishing between tax avoidance and tax evasion in Mclaren (2008), pp. 141-163; Baker (2013), pp. 3-17; Neck, Wächter, and Schneider (2012), pp. 104-117; Stiglitz (1985), pp. 32538. Thus tax evasion generally triggers criminal liability. See Templeman (1997), p. 1. In Poland, tax evasion is an offence, see Article 54 of Fiscal Penal Code (1999). See more in Brzeziński (2007), pp. 87-91.
} 
taxation, by achieving lower tax rates or by avoiding income tax altogether. ${ }^{59}$ The first element removes tax avoidance behaviour from the scope of tax evasion, the second from tax planning. The second element contradicts the spirit of tax law, which accounts for the fact that tax avoidance is usually not tolerated by tax authorities, courts and legislators.

That being said, CFC tax avoidance may be understood as the establishment of a foreign controlled entity (usually a company) or entities usually, but not necessarily, in a tax haven or a low-tax jurisdiction by taxpayers controlling this entity (CFC participants) in order to defer/diminish/totally avoid taxation by diverting income to this entity or entities before its taxation in the state of residence of the controlling taxpayers. ${ }^{60}$ Taxpayers use many and various techniques to achieve such tax avoidance effects. The techniques have several characteristics in common, however, particularly transactions or arrangements with little or no pre-tax profits which rely wholly or substantially on anticipated effects of tax avoidance mechanisms to facilitate significant post-tax profits. Such transactions or arrangements typically have little or no business, commercial, or non-tax purpose and involve contrived, transitory, pre-ordained, or commercially unnecessary (artificial) steps for their realization. Following their realization, no or little economic substance is created and their tax implications are normally not commensurate with the change in the economic position of the taxpayer or taxpayer group - a significant change is, however, noticeable in their tax position. ${ }^{61}$

So the term "CFC tax avoidance", as it is used in this study, refers to transactions and schemes that are not accepted by most states, and to "suspicious" transactions and schemes that are potentially unacceptable and are, or should be, investigated.

Before turning to the analysis of economic data and schemes regarding CFC tax avoidance, it is worth briefly describing the effects of this phenomenon on various socioeconomic stakeholders. In general, it increases the competiveness of the taxpayers involved, but has several negative consequences for other concerned parties.

First, avoiding tax via CFCs is a feasible option only for the very wealthy, since establishing and exploiting CFCs is efficient only if the income diverted to the CFCs is substantial. It consequently benefits the taxpayers who have the kind of resources that enable them to avoid taxes in this way, while disadvantaging those without such resources. This is contrary to the principle of horizontal equity, i.e., the principle of the taxpayer's ability to pay

\footnotetext{
${ }^{59}$ Cf. Piccioto (1992), p. 92.

${ }^{60}$ Cf. Evans, (2009), p. 533.

${ }^{61}$ Id., pp. 536-537.
} 
taxes. ${ }^{62}$ CFC tax avoidance is also likely widen the gap between the poorest and the richest, and may adversely affect sustainable development. ${ }^{63}$

Second, it erodes the tax base of the CFC participants' resident states and undermines the integrity of the tax system insofar as the media and ordinary taxpayers perceive the lowtaxation levels enjoyed by MNEs and very wealthy individuals as unfair. ${ }^{64}$

Third, it can harm fair competition inasmuch as domestic enterprises, such as familyowned businesses, new and innovative companies and enterprises operating internationally without the ambition, moral laxity or possibility to avoid taxation via CFCs may find it harder to compete with taxpayers who shift profits across borders to avoid or minimize tax. ${ }^{65}$

Thus, CFC tax avoidance fails to meet the expectation according to which all members of the socio-economy should pay their fair share of taxes and thus contribute to the collective missions run by the state as a collective entity. The same may be concluded about corporate social responsibility as companies are expected to contribute to the social welfare on a fair and level playing field with other taxpayers.

Considering the negative consequences of CFC tax avoidance, Member States should work hard within the legal framework of the EU to create tax systems that are efficient at preventing this phenomenon.

\section{3 "CFC tax avoidance": Economic data and schemes, globally and in Poland}

\subsection{Introduction: Definitional issues}

Following the general description of the basic features of CFC tax avoidance given above, this part turns to economic data and CFC tax avoidance schemes. While the present study will not apply any economic theory nor conduct any empirical studies of CFC tax avoidance, reference will be made to data gathered and published by international organizations (OECD and International Monetary Fund, IMF), the Polish Ministry of Economy, tax authorities and legal literature.

Realizing foreign direct investments (FDIs) through companies established in tax havens or low-tax jurisdictions is likely to be linked to efforts to avoid tax through the use of CFCs if these jurisdictions are not places where genuine investments are usually made. Hence,

\footnotetext{
${ }^{62}$ See Birk (2000), p. 104. Cite after: Selera (2010), No. 118234. Cf. infra 15.4.2.

${ }^{63}$ See Kuźniacki (2012), pp. 141-142.

${ }^{64}$ Cf. OECD (2013), p. 8.

${ }^{65}$ Cf. OECD (2013), p. 8.
} 
in order to ascertain whether taxpayers are avoiding taxation through the use of CFCs, globally and in the case of Poland specifically, it is useful to determine whether they make FDIs through CFCs located in tax havens or low-tax jurisdictions.

In sections 3.1.1-3.1.4 I will explain a few definitional issues which are of fundamental importance for understanding the relevance of analysed data with respect to the scale of CFC tax avoidance globally and in Poland. Then in section 3.2, I will analyse economic data and schemes shedding light on CFC tax avoidance on a global scale. In section 3.3, I will focus on the CFC tax avoidance environment of one of the EU member states Poland. Finally in section 3.4, I will conclude on this part of the study.

\subsubsection{Foreign direct investment (FDI)}

According to the OECD, FDI involve the direct or indirect ownership of 10 percent or more of the voting power of an enterprise resident in one economy by an investor resident in another and it is therefore assumed that such a relationship usually leads to the exercise of significant influence by this investor on an enterprise resident in a foreign country. ${ }^{66}$ In my view, however, a person who retains 10 percent or more of a foreign company's voting rights cannot be automatically considered as having or not having a definite influence over the foreign company - a controlling stake whereby he can take decisions that determine its activities. A person may hold less than 10 per cent of the shares of a CFC, but still exert real/factual control over the foreign company, if, for example, the remaining ownership structure is widely spread or control exists due to an agreement between the participant and the foreign company, especially if this company is directly owned by only ten persons holding 10 percent of its shares per capita. The opposite may also be true, i.e. a 10 percent or more ownership may not necessarily confer decisive control over a foreign company if such control is attributed to other persons. ${ }^{67}$ As a matter of fact, the OECD confirms some of the issues I have dealt with above, but it concludes that "the recommended methodology does not allow any qualification of the $10 \%$ threshold and recommends its strict application to ensure statistical consistency across countries." 68

Moreover, the OECD indicates that FDIs include, among other things, "inward and outward financial transactions/positions between directly and indirectly owned incorporated

\footnotetext{
${ }^{66}$ See OECD (2008), paragraph 117 at pp. 48-49.

${ }^{67}$ Cf. TPCA (2015), p. 2. See also relevant issues of organizational-decoupling and equity-decoupling in AnkerSørensen (2016).

${ }^{68}$ See OECD (2008), paragraph 117 at p. 49.
} 
and unincorporated enterprises." 69 This means that FDIs include pure financial flows between parent companies and their subsidiaries, including the transfer of highly mobile incomes to CFCs from their controlling participants. It may therefore be assumed that realizing FDIs through companies established in low-tax EU jurisdictions is likely to be linked to efforts to avoid tax through the use of CFCs if these jurisdictions do not coincide with places where genuine investments are usually made. Distinguishing between tax driven and non-tax driven transactions concerning FDIs is therefore fundamental in order not to confuse strategic uses of FDIs for legitimate economic activities (i.e. non-tax driven activities) with their use for the sole or predominant purpose of avoiding taxes.

In order to ascertain whether taxpayers are avoiding taxation through the use of CFCs, globally and, in the case of Poland, specifically, it is useful to determine whether they make FDIs through companies located in low-tax EU jurisdictions.

\subsubsection{Multinational enterprise (MNE)}

There is no a precise and legally binding definition of a MNE, but for the purposes of this study, the open-ended definition of the OECD is relevant. It says that MNEs:

usually comprise companies or other entities established in more than one country and so linked that they may coordinate their operations in various ways. While one or more of these entities may be able to exercise a significant influence over the activities of others, their degree of autonomy within the enterprise may vary widely from one multinational enterprise to another. Ownership may be private, State or mixed. ${ }^{70}$

The literature indicates that MNE can be defined as an enterprise which wholly or partly owns, controls, and manages value-adding activities in more than one country. ${ }^{71}$ MNEs typically consist of groups of companies that are highly interrelated economically and legally and are often under the control of an ultimate parent. ${ }^{72}$ It is therefore likely that the companies used for tax avoidance purposes, for instance CFCs, will be found within the group of MNEs. $^{73}$

\subsubsection{Special Purpose Entity (SPE)}

Beyond the data on FDIs and MNEs, I also refer to other relevant data and statistics. In that regard, it should also be explained that these global data and statistics do not refer explicitly to

\footnotetext{
${ }^{69}$ See OECD (2008), paragraph 119 at p. 49.

${ }^{70}$ See OECD (2011), p. 17.

${ }^{71}$ Cf. Brewer and Young (1998), p. 11.

${ }^{72}$ See more Strasser and Blumberg (2011).

${ }^{73}$ See OECD (2011), p. 17. Cf. Brewer and Young (1998), p. 11.
} 
foreign companies used for tax avoidance purposes, usually called CFCs, but to entities that, from a functional point of view, may largely be identified with such companies as Special Purpose Entities (SPEs). Even though there is no legal definition of an SPE, according to the OECD, a company is usually considered as an SPE

if it meets the following criteria: i) the enterprise is a legal entity, a) formally registered with a national authority; and b) subject to fiscal and other legal obligations of the economy in which it is resident; ii) the enterprise is ultimately controlled by a non-resident parent, directly or indirectly; iii) the enterprise has no or few employees, little or no production in the host economy and little or no physical presence; iv) almost all the assets and liabilities of the enterprise represent investments in or from other countries; v) the core business of the enterprise consists of group financing or holding activities, that is - viewed from the perspective of the compiler in a given country - the channelling of funds from non-residents to other non-residents. However, in its daily activities, managing and directing local operations plays only a minor role. ${ }^{74}$

This definition implies that SPE in its structure and substance vastly corresponds to a CFC. Moreover, the core business of an SPE, which in the OECD's view is a group financing or holding activities, does not necessary rely on channelling funds from non-residents to other non-residents, as in the case of conduit companies. The group financing or holding activities may either be used for receiving and accumulating an income over long periods and thus serve for tax deferral and/or to repatriate this income later in jurisdictions without taxation or with low-taxation, which corresponds to the core function of CFCs and base companies.

\subsubsection{Base companies vs conduit companies}

According to the OECD nomenclature, a base company may be considered: (i) a company or an entity treated for tax purposes as body corporate that is (ii) predominantly established in a low-tax jurisdiction by its controlling participants for the purposes of a deferral of taxation on their income (primary sheltering of income) and/or repatriation of this income without taxation or with effectively low-taxation, i.e. tax avoidance (secondary sheltering of income). ${ }^{75}$ In that regard, the function of base companies - accumulating income in low- or no-tax jurisdiction for purposes of tax deferral/tax avoidance - should be distinguished from

\footnotetext{
${ }^{74}$ See OECD (2008), paragraph 558.

${ }^{75}$ See OECD (1986), paragraphs 1-12. Historically the term "base company" was used for the first time by W. J. Gibbons. See Gibbons (1956), p. 1207. See also Rapakko (1989), pp. 8-11.
} 
the function of conduit companies which is "channelling" income from one country to another for purposes of "treaty shopping" and/or "directive shopping". ${ }^{76}$

Taking into account the function of CFCs,${ }^{77}$ it is clear that these companies can be identified with base companies, not with conduit companies. This finding also stems from the research led by the OECD on base companies, which suggests that CFC rules ("Subpart-F type counteracting legislation" in the OECD's language) constitute specific legislation against the sheltering of income in low-taxed base companies situated abroad. ${ }^{78}$

Nevertheless, in many cases, tax avoidance schemes, including CFC schemes, do not rely exclusively on base companies, but also on conduit companies, and the combined effects of both will yield tax benefits to the participants. ${ }^{79}$ Likewise, although Polish data and statistics do not specifically refer to companies that are engaged in tax avoidance practices, it appears that they also take into account situations in which such companies are very likely to be engaged.

\subsection{Global data and schemes}

\subsubsection{Global data}

The IMF's Co-ordinated Direct Investment Survey presents interesting data on FDIs realized via entities established in tax havens. In 2010, Barbados, Bermuda and the British Virgin Islands received more FDIs (in sum 5.11 per cent of global FDIs) than Germany (4.77 per cent) or Japan (3.76 per cent) and more outward investments were transacted from those countries (in sum 4.54 per cent) than from Germany (4.28 per cent). Comparing the number of FDIs by country, in 2010 the British Virgin Islands were the second largest investor in China (14 per cent), after Hong Kong (45 per cent), and before the United States (4 per cent). Also in 2010, Bermuda was the third largest investor in Chile (10 per cent); Mauritius the top investor country in India (23 per cent); while Cyprus (28 per cent), the British Virgin Islands (12 per cent), Bermuda ( 7 per cent), and the Bahamas (6 per cent) were among the top five investors in Russia. ${ }^{80}$

Interesting information can be obtained from the OECD Investment Database on FDI stock positions, which are composed of equity and debt (intercompany loans) and represent

\footnotetext{
${ }^{76}$ See the comprehensive distinction of functions between base and conduit companies in the context of tax avoidance in De Broe (2008), pp. 5-61. See also OECD (1986) and OECD (1986a).

${ }^{77}$ See supra 2.2 .

${ }^{78}$ See OECD (1986), paragraph 23.

${ }^{79}$ See Piccioto (1992), pp. 137-139; Fuest et al. (2013), pp. 310-314.

${ }^{80}$ See OECD (2013a), p. 17.
} 
the value of the stock of direct investments held at the end of the reference period (year, quarter, or month). ${ }^{81}$ Data on FDIs composed of equity and debt are especially interesting from the perspective of tax avoidance because financial instruments related to equity and debt are often used in cross-border intercompany loans for tax avoidance purposes via the hybrid qualification of such instruments whereby the financial instrument is treated by the issuer state as debt and by the holder state as equity, often resulting in a payment of tax deductible interest by the issuer, which is then exempted from taxation in the holder's state due to the treatment of this payment as dividend (participation exemption). ${ }^{82}$

These data show that total inward stock investments into the Netherlands (usually used for establishing conduit companies for treaty and EU Directive shopping purposes) ${ }^{83}$ for 2011 were equal to USD 3,207 billion and the amount of USD 2,625 billion was realized via SPEs (note the close similarity in structure and substance of SPEs and CFCs); ${ }^{84}$ outward stock investments from the Netherlands were equal to USD 4,002 billion, with about USD 3,023 billion being made through SPEs. In the case of Luxembourg (a low-tax jurisdiction which is most likely often used for exploiting CFCs for tax avoidance purposes), ${ }^{85}$ total inward stock investments for 2011 were equal to USD 2,129 billion, with USD 1,987 billion being made through SPEs. Outward stock investments from Luxembourg were equal to USD 2140 billion, with about USD 1,945 billion being made through SPEs. ${ }^{86}$

The jurisdictions indicated above have tax systems whereby income (at least various types of passive income) derived by base companies, in the vast majority of cases CFCs, is not taxed at all or only very moderately. The income derived by SPEs functioning as conduit companies (usually established in the Netherlands for treaty and EU Directive shopping purposes), in turn, is usually not taxed because their taxable expenses almost equal their gross

\footnotetext{
${ }^{81}$ Id., p. 22.

${ }^{82}$ See OECD (2015b), paragraph 18 and OECD (2014a), p. 34, paragraph 54.

${ }^{83}$ Income derived by conduit companies is normally not taxed in the Netherlands because their taxable expenses almost equal their gross income, i.e. their taxable base is close to zero. Moreover, the Netherlands have a large network of tax treaties, and offer protection under EU law, including EU directives exempting dividend, interest and royalty payments from taxation. Cf. infra 3.2.2 and the literature indicated there regarding "Double Irish Dutch Sandwich" CFC tax avoidance structure.

${ }^{84}$ See OECD (2008), paragraph 558.

${ }^{85}$ See the database of the International Consortium of Investigative Journalists revealing that hundreds of schemes have been identified in secret tax agreements approved by the Luxembourg tax authorities, available online at: http://www.icij.org/project/luxembourg-leaks/explore-documents-luxembourg-leaks-database. See more about the Luxembourg tax system in Bardini and Lambio (2015); Warner and Schmitz (2004). See infra 3.3.1 and 3.3.2.2 for economic data and analysis of "Luxembourg CFC scheme" respectively implying that Luxembourg is frequently used by Polish taxpayers for CFC tax avoidance purposes.

${ }^{86}$ See OECD (2013a), p. 18.
} 
income, i.e. their taxable base is close to zero. ${ }^{87}$ In that regard, it is also worth reiterating the close similarity in structure and substance of SPEs and CFCs ${ }^{88}$ and further, that Luxembourg can be seen as a low-tax jurisdiction for exploiting CFCs for tax purposes. ${ }^{89}$

Furthermore, senior members of the OECD Centre for Tax Policy and Administration (CTPA) have commented on the context of the implementation of OECD/G20 efforts to curb tax avoidance by multinationals, saying that around 80 per cent of global gross income is currently (2015) generated by 15 per cent of MNEs with large networks of controlled subsidiaries around the world. ${ }^{90}$ These controlled subsidiaries are not necessarily CFCs, but one may assume that at least some of them are, since companies within the group of MNEs are actually controlled by an ultimate parent and their income is dispersed around the world, including low-tax jurisdictions and tax havens. ${ }^{91}$

These global data imply that a significant percentage of global inbound and outbound investments are realized through entities whose characteristics largely match those of companies established in tax havens and low-tax EU jurisdictions for CFC tax avoidance purposes. ${ }^{92}$ It is therefore highly likely that the taxation of a substantial amount of global income is deferred or avoided via CFCs established within the EU. This assumption may be further verified by a brief discussion of selected international tax avoidance schemes within the EU.

\subsubsection{A brief discussion of selected international tax avoidance schemes within the EU}

There are several examples of tax avoidance schemes operated by global MNEs whose features are not dissimilar to those of CFC tax avoidance schemes (see section 2.4). In this section, I will mention some that have attracted the analytical attention of scholars. I will not analyze these international schemes myself, although I do cite the appropriate sources and recapitulate the conclusions that scholars have reached.

\footnotetext{
${ }^{87}$ Cf. infra 2.3 and the literature indicated there regarding "Double Irish Dutch Sandwich" CFC tax avoidance structure.

${ }^{88}$ See supra 2.2.

${ }^{89} \mathrm{Cf}$. supra 2.1.2.2. See more about the Luxembourg tax system in Bardini and Lambio (2015); Warner and Schmitz (2004).

${ }^{90}$ See OECD (2015h)

${ }^{91}$ See infra 3.2.2.

${ }^{92}$ See supra 2.2 and 3.1.3-3.1.4.
} 
Some tax avoidance schemes are particularly interesting since they are known across the world and because of the amount of avoided tax involved. They include schemes run by Google Inc. ("Double Irish Dutch Sandwich"); ${ }^{93}$ Apple Inc. $;{ }^{94}$ Caterpillar; 95 and Starbucks. ${ }^{96}$

After analyzing information from parliamentary hearings in the US and the UK, scholars estimate that Apple, Google, and Caterpillar have managed to reduce effective tax on their foreign-sourced income to about 1,2 , and 4 per cent, respectively. ${ }^{97}$ With respect to Apple, the hearing confirms that from 2009 to 2012, "it successfully sheltered U.S. \$44 billion from taxation anywhere in the world." ${ }^{98}$ In relation to Starbucks UK, the hearing indicates that this MNE "has paid $£ 8.6$ million of U.K. corporate tax during its 15-year existence on revenue of more than $£ 3.4$ billion." 99 In the cases of Apple, Google, and Caterpillar, scholars have concluded that one of the most important elements of their schemes is their circumvention of US CFC rules due to certain flaws affecting the latter, most importantly the check-the-box regime and use of EU law. ${ }^{100}$ Similar conclusions can be drawn with respect to other tax avoiders, such as Microsoft, Hewlett-Packard, and Amazon. ${ }^{101}$

Thus, CFC tax avoidance is possible in relation to income generated by various types of activities, including intangibles (Apple, Google, Microsoft, Hewlett-Packard, Amazon) and tangibles (Caterpillar and Starbucks) and therefore passive as well as active income. Most importantly, the recognized schemes have been effective not only with regard to income from activities that can be located remotely from the physical location of their customers in the EU or elsewhere (Apple, Google, Microsoft, Hewlett-Packard, Amazon, and Caterpillar), but also when such activities must be located in the customer's location (Starbucks) within the EU.

In it also worth referring to CJEU judgment of 13 March 2007 in Test Claimants in the Thin Cap Group Litigation case ${ }^{102}$ in which US multinationals, Pepsi and Caterpillar, used EU-based companies, in Luxembourg and Ireland (a Swiss company was also involved in case of Caterpillar) among others, in order to provide loans to the UK company. ${ }^{103}$ I am not

\footnotetext{
${ }^{93}$ See Fuest et al. (2013), pp. 310-312; Sandell (2012), pp. 868-877.

${ }^{94}$ See Ting (2014), pp 42-55.

${ }^{95}$ See Ting (2014a), pp. 243-246.

${ }^{96}$ See Kleinbard (2013), pp. 1519- 1531.

${ }^{97}$ See Sandell (2012), p. 867; Ting (2014a), p. 243, footnote 35; Ting (2014), p. 55; Fuest et al. (2013), p. 307; Sullivan (2012), p. 655.

${ }^{98}$ See U.S. Hearing Report (2013), p. 17. Cite after: Ting (2014), p. 40.

${ }^{99}$ See House of Commons Public Accounts Committee (2013), paragraph 10. Cite after: Kleinbard (2013), p. 1520 .

${ }^{100}$ See Ting (2014), pp. 45-46 and (2014a), p. 244-246 and (2015), p. 50-54; Fuest et al. (2013), p. 213; Van Weeghel and Emmerink (2013), p. 434.

${ }^{101}$ See Ting (2014), p. 41, footnote 2.

102 C-524/04.

${ }^{103}$ C-524/04, paragraph 19.
} 
here to judge whether or not the said EU-based companies were used for CFC tax avoidance purposes, but Antony Ting convincingly argued that the Caterpillar scheme could be seen as a tax avoidance scheme ${ }^{104}$ while the Pepsi scheme, based on the use of the Luxembourg tax jurisdiction, is on the list of the International Consortium of Investigative Journalist revealing secret tax agreements approved by the Luxembourg tax authorities. ${ }^{105}$

\subsubsection{Interim conclusions}

As the above review reveals, a lion's share of global inbound and outbound FDIs are likely to be conducted for tax avoidance purposes. Such FDIs rely on pure financial flows between controlled entities established in tax havens and EU low-tax jurisdictions. The functional characteristics of the entities largely match those of CFCs. It will be interesting to see whether a similar conclusion can be drawn in relation to tax avoidance in one of the EU member states - Poland.

\subsection{Polish data and schemes}

\subsubsection{Polish data}

Based on the "Report on Polish Direct Investments in 2011" by the Department of Economic Analysis and Forecasting at the Polish Ministry of Economy (Report 2011) ${ }^{106}$, figure I below indicates a rapid increase in the value of Polish FDIs as of 2002, ${ }^{107}$ from PLN 228 million in 2002 to PLN 2702 million in 2005, even glancing PLN 7132 million in 2006. ${ }^{108}$ For the period 2007-09, the following figures are given: PLN 3952 million, PLN 3011 million, PLN 3745 million. In 2010 and 2011, FDIs reached 5484 million and 5276 million, respectively. The significant increase in the value of FDIs beginning in 2004 may be explained by Poland's accession to the EU. Polish investors could now enjoy freedom of establishment within the

\footnotetext{
104 Ting (2014), pp. 237-247 and (2015), pp. 413-414.

105 See database available online at: http://www.icij.org/project/luxembourg-leaks/explore-documentsluxembourg-leaks-database.

${ }^{106}$ Ministry of Economy of Poland (2013). The reason I refer to the 2011 Report is that the latest report (2013) does not refer to FDIs before 2000, which in itself may be interesting given the historical changes in the Polish economy. I refer of course to the most updated report of 2013 as well.

107 The main reason for such a low amount of FDIs in 1990s was, in brief, that legal restrictions related to investing abroad remained in place throughout the 1990s. See Ministry of Finance, No. 16, item 197; Polish Department of Exchange (1996), pp. 189-191. But it was also caused by a lack of financial infrastructure and know-how permitting significant investments abroad. See Karaszewki (2009), p. 33; Jaworek (2008), p. 64; Góral (2000), pp. 334-340; Piach (2001).

108 The remarkably high level of FDIs in 2006 was achieved primarily through a single transaction: the purchase of the Lithuanian refinery Maźeikiai by PKN Orlen, the largest Polish foreign investment before 2013. This information supports the fact that foreign investments by Polish taxpayers fell the following year by almost PLN 3000 million relative to 2006 numbers. See Report 2013, p. 12.
} 
EU and free movement of capital without territorial limitations, both of which are important for FDIs.

As the 2011 Report (p. 16) shows, as of 2011, the highest value FDIs were located in low-tax jurisdictions with preferential income tax regimes, Luxembourg and Cyprus; the amounts were EUR 2851.6 million and EUR 1257.7 million, respectively. In comparison, considerably smaller amounts were invested in high-tax countries with robust tax systems, such as France and the US: EUR 479.8 million EUR and 236.7 million, respectively.

The "Report on Polish Direct Investments in 2013" by the Department of Strategy and Analysis at the Ministry of Economy (Report 2013) ${ }^{109}$ also gives Cyprus first place as the preferred destination for FDIs, with the value peaking at EUR 443.8 million. Interestingly, this report also says that FDIs in Cyprus were made by companies established there although their transactions were usually conducted and their financial resources usually based outside Cyprus. ${ }^{110}$ These companies then functioned as typical base and conduit companies that can be qualified as SPEs, ${ }^{111}$ implying that the FDIs were made for tax avoidance purposes.

Another interesting observation follows from the 2013 Report. Over the 2000-13 period, most of the Polish FDIs took place in European low-tax jurisdictions, such as Luxembourg (EUR 6877 million or 33.3 per cent) and Cyprus (EUR 4514 million, or 21.9 per cent), and in jurisdictions with preferential tax regimes, for example the Netherlands (EUR 1776 million, or 8.6 per cent) and Switzerland (EUR 1968 million, or 9.5 per cent). ${ }^{112}$

As of 2013, the most attractive among Asian countries was Singapore (EUR 131 million), ${ }^{113}$ taking the place the United Arab Emirates (EUR 19.2 million) held in 2011. ${ }^{114}$ Both are low-tax jurisdictions. ${ }^{115}$

The 2011 Report (pp. 17 and 18) also underlines the divergence between these Polish FDIs in the above-mentioned countries, particularly Cyprus, Luxembourg, Switzerland, and the Netherlands (and in 2010 Belgium and the Isle of Man), and typical FDIs, such as acquisitions of foreign companies, acquisitions of significant shareholdings in foreign companies or direct investments through the establishment of a completely new branch of a Polish company for purposes of conducting major economic activity. Instead, they relied

\footnotetext{
${ }^{109}$ Ministry of Economy of Poland (2015).

110 The Report 2013, p. 18.

${ }^{111}$ See supra 3.2.1.

112 The Report 2013, p. 18.

113 The Report 2013, p. 18.

114 The Report 2011, p. 15.

${ }^{115}$ For more see Umar (2015) and Gueydi (2015).
} 
exclusively on financial flows between parent companies and their subsidiaries, although they remain classified as FDIs. ${ }^{116}$

Further, the companies located in the above-mentioned jurisdictions were initially controlled by Polish taxpayers and mostly operated as holding companies that were disengaged from any form of genuine economic activity beyond the transfer of dividends between companies in the group. Neither did these companies have subsidiaries in the countries of their incorporation where they were engaged in economic activity. The Report states that, for example, Russia constituted the biggest market for Polish FDIs as of 2011. In that country, Polish FDIs relied mostly on manufacturing and trading (a dynamic development of a network of Polish shops). In comparison, Polish FDIs in Cyprus were mainly involved in establishing holding companies there, without any subsidiaries engaged in active business in that country. ${ }^{117}$

Taking this information in the round, the majority of the income derived from the FDIs of Polish investors in the last 10 years would appear to originate via CFCs in low-tax jurisdictions. It is therefore highly likely that the sole or predominant purpose of such investments was to create CFCs in low-tax jurisdictions in order to avoid taxation in Poland or elsewhere. It may also be assumed that tax avoidance via CFCs constitutes one of the most widely used ways of avoiding tax by Polish taxpayers and that Poland has suffered from the lack of effective anti-CFC tax avoidance provisions in the period in question.

That being said, it will be interesting to identify and analyze the CFC tax avoidance schemes set up by Polish taxpayers in order to see if there is any correlation between the economic data and statistics on the one hand and the locations of these CFCs as well as the use Polish taxpayers make of them on the other hand.

\footnotetext{
116 The Report 2011, p. 17.

117 The Report 2011, pp. 17-18.
} 
Figure I: The value of outward FDIs of Polish investors 1994-2011 in millions of PLN ${ }^{118}$

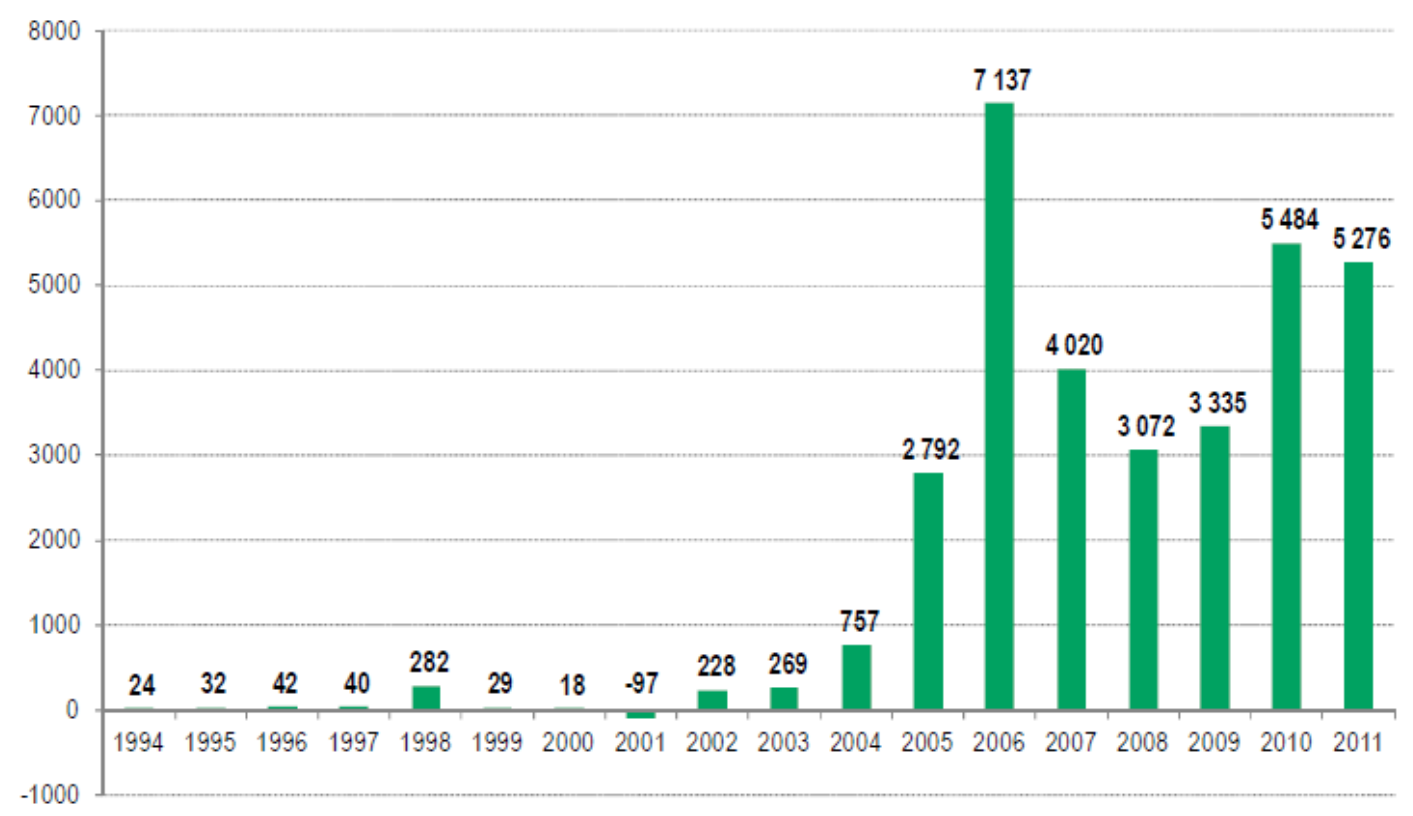

Source: Polskie Inwestycje Bezpośrednie w 2011 roku, Departament Strategii i Analiz Ministerstwa Gospodarki, March, 2013, Warsaw, p. 13.

\subsubsection{Selected tax avoidance schemes by Polish taxpayers}

There are several instances of CFC tax avoidance schemes put in place by Polish taxpayers that match the features of the schemes described earlier in section 2.4. This section focuses on three well-known Polish schemes. The first has been named "Double Cypriot Olive with a Polish Potato" in an obvious nod to Google's CFC tax avoidance scheme known as "Double Irish with a Dutch Sandwich". The second is called "Luxembourg CFC Scheme" because the Polish taxpayers use the tax jurisdiction of Luxembourg to avoid taxation. The third is known as the "LPP Scheme", named after the Polish enterprise involved in avoiding taxation via this scheme. After presenting and analyzing these schemes, I will draw the tax-related implications stemming from their exploitation by Polish taxpayers.

I identified each of these schemes by analyzing individual advance tax rulings, publicly available on the website of the Ministry of Finance ${ }^{119}$, or investors' relations on the official website of the company involved in the scheme ("LPP Scheme"). ${ }^{120}$ These schemes have not been previously described in the literature by other scholars. ${ }^{121}$ It should also be noted that the analysis is essentially illustrative and may not reflect precisely all relevant tax

\footnotetext{
${ }^{118}$ EURO 1 equals PLN 4,0179 as of 5 May 2015 according to the Polish National Bank average exchange rate. Available online at: http://www.nbp.pl/home.aspx?f=/statystyka/kursy.html.

119 http://sip.mf.gov.pl/sip/.

120 See the LPP's official website, in its part regarding investor relations: http://www.inwestor.lpp.com.pl/en/index.html.

${ }^{121}$ Only the "LPP Scheme" was depicted and published before in the Polish edition of Forbes. It was, however, done by me. See Kuźniacki (2014e).
} 
and investor issues. The accompanying Figures were created by myself. For the sake of simplicity and clarity of presentation, I ignore general partners in limited partnerships (LPs, spółka komandytowa in Polish), which are normally Polish limited liability companies (LLCs, spółka z ograniczona odpowiedzialnościa in Polish) ${ }^{122}$ and I do not identify every single investor in the investment funds, such as the Private International Collective Investment Scheme (PICIS). ${ }^{123}$

Due to the amendment to the Polish tax law that entered into force very recently (1 January 2017) in an effort to prevent tax avoidance, some elements in the schemes are not or may not be currently valid from a taxation point of view. Nevertheless, the presentation and analysis of those schemes remain relevant for understanding the legal, economic and factual contexts existing in Poland at the time of flourishing of blatant CFC tax avoidance schemes.

\subsubsection{1 "Double Cypriot Olive with a Polish Potato": Total tax avoidance of Polish- sourced income}

To set up the scheme illustrated below in Figure II, a Polish taxpayer, being an individual who runs a business in Poland via a Polish LP, first transfers participation in the Polish LP (rights and duties) personally owned by him to a Cypriot Alternative Investment Fund (AIF) ${ }^{124}$ he has recently established. Transfer of participation rights in the Polish LP is done as an in-kind contribution in exchange for shares in the Cypriot AIF, and is a tax-neutral transaction (there is no income to be taxed). ${ }^{125}$ Consequently, the Cypriot AIF participates almost 100 per cent

\footnotetext{
${ }^{122}$ In practice, CFC schemes with investment funds and polish LPs are structured in such a way that the fund is a limited partner of the LP with almost total participation percentage in this entity ( 99.99 percent) and the remaining participation percentage (0.01 percent) belongs to a Polish LLC. In consequence, not only tax, but also the civil liability (liability for obligations) of the Polish LP is reduced to zero, see Kuźniacki (2013b), pp. 921. This holds true for all CFC schemes analyzed in the study unless stated otherwise.

${ }^{123}$ PICIS regime was replaced by the Alternative Investment Fund (AIF) regime on 10 July 2014, see Mylonas (2015).

${ }^{124}$ AIF regime replaced Private International Collective Investment Schemes (PICIS) regime on 10 July 2014 , see Mylonas (2015).

${ }^{125}$ Pursuant to Article 13(4) of the Poland-Cyprus tax treaty, an income from the alienation of shares (in-kind contribution) of a Polish LP to a Cypriot PICIS will be taxable only in Poland (the residence State of an alienator). According to the Polish tax law, no taxable income appears if the shares of the Cypriot PICIS have been acquired as a result of the in-kind contribution of the participation in the Polish LP only up to the amount of the nominal value of the shares of the Cypriot PICIS, and if the part of the increase of the contributed participation in the Polish LP over the acquired nominal value of the shares of the Cypriot PICIS has been allocated to the supplementary (reserve) capital of the Cypriot PICIS. In that case taxable costs will be equal to the revenue and thus no taxable income appears (nil tax base), see Article 17(1) point 9 in conjunction with Article 22(1e) PITA. However, the new law, applicable from 1 January 2017, may not allow for the tax neutrality of that transaction. The law stipulates that the market value of the in-kind contribution is to be included in the taxable income of the person making such contribution to a company in exchange for shares. See Articles 1 and 2 of the Act amending Personal Income Tax Act and Corporate Income Tax Act of 27 September 2016, Journal of Laws of 27 September 2016, item 1550 (Ustawa z dnia 27 września 2016 r. o zmianie ustawy o
} 
in the Polish LP wholly or mainly engaged in active business activity in Poland. The Polish taxpayer, in turn, owns shares in the Cypriot AIF and is entitled to receive dividends from this entity. The Polish taxpayer is an influential investor in the AIF and most likely has the right to select the members of the board of directors of the Cypriot AIF and give them binding instructions. It is therefore very likely that the Polish taxpayer exerts definite control over the Cypriot AIF.

The Polish LP constitutes a foreign PE for the Cypriot AIF under the Poland-Cyprus tax treaty. The income generated by the Polish LP is exempt from taxation in Poland (the source state) as well as in Cyprus (the residence state). The former is based on the subjective exemption from CIT in Poland of collective investment funds with a registered office in a Member State of the EU (Cyprus). ${ }^{126}$ The latter relies on the exemption from taxation under the Cypriot domestic tax law according to which the profits of a foreign PE are exempted from income tax in Cyprus if the PE derives directly or indirectly more than 50 per cent of its profits from an active business. ${ }^{127}$ This condition is fulfilled by this scheme since the Polish LP is wholly or mainly engaged in an active business such as construction or pharmaceutics.

Next, the Polish taxpayer establishes a tax transparent LP in Cyprus, to which he transfers shares in the AIF, personally owned by him in advance, to the Cypriot LP. The transfer of shares in the AIF is done as an in-kind contribution in exchange for participation in the Cypriot LP, and is a tax-neutral transaction (there is no income to be taxed). ${ }^{128}$ Consequently, the Cypriot LP owns all the shares that were previously owned by the Polish taxpayer and therefore the Cypriot LP is entitled to receive income from the AIF in the form of dividends.

The Polish taxpayer, in turn, is entitled to receive income from the Cypriot LP on an ongoing basis, since under the Poland-Cyprus tax treaty, it constitutes a foreign PE for him. Since the Cypriot LP is tax-transparent from the point of view of both Cypriot and Polish tax laws, the look-through approach applies to dividends paid by PICIS to the Cypriot LP - the recipient of the dividends is considered to be a foreign tax resident, i.e. a Polish taxpayer, but

podatku dochodowym od osób fizycznych oraz ustawy o podatku dochodowym od osób prawnych, Dz. U. 2016, Poz. 1550).

${ }^{126}$ Art. 6(1) point 10a CITA. However, this exemption has not been applied since 1 January 2017. Instead, the new law exempts from taxation all income from open-ended funds and all income from closed-end funds apart from the income derived from the participation in profits from tax transparent partnerships. See Article 2 of the Act amending Personal Income Tax Act, Corporate Income Tax Act, Tax Ordinance and some other Acts of 29 November 2016, Journal of Laws of 29 November 2016, item 1926 (Ustawa z dnia 29 listopada 2016 r. o zmianie ustawy o podatku dochodowym od osób fizycznych, ustawy o podatku dochodowym od osób prawnych oraz ustawy o zmianie ustawy - Ordynacja podatkowa oraz niektórych innych ustaw, Dz. U. 2016, Poz. 1926).

127 See KMPG (2015), p. 9.

${ }^{128}$ See supra f the Act amending Personal Income Tax Act, Corporate Income Tax Act, 
not a Cypriot taxpayer. Therefore no taxes are withheld on dividends paid to non-resident individuals, because all dividends paid out of Cyprus to non-residents are exempt from tax under Cypriot domestic law. ${ }^{129}$

Dividends received by the Polish taxpayers via the Cypriot LP qualify as profits from a foreign PE, i.e. business income taxable under Article 7(7) in conjunction with Article 10(4) of the Poland-Cyprus tax treaty. The credit method applies to such income in Poland pursuant to Article 24(1)(b) of the Poland-Cyprus tax treaty. The foreign business income of Polish taxpayers, however, qualifies under Polish domestic law as income from economic activity and falls within the scope of the so-called tax abolition relief. ${ }^{130}$ The tax effects of this relief are analogous to the exemption method. ${ }^{131}$ Consequently, this income is not taxed in Cyprus nor is it in Poland.

As a result of this tax avoidance scheme, business income originally generated in Poland avoids taxation altogether on a current basis. Since Polish domestic law allows for the final non-taxation of the income repatriated from Cyprus, this scheme cannot be deprived of its tax effectiveness by amending the treaty with Cyprus. It could be though by amending the Polish domestic law. ${ }^{132}$ The tax effects of this scheme were confirmed by several advance tax rulings. ${ }^{133}$

The directors of some tax chambers, however, have challenged the opportunity to exempt from taxation an AIF's income derived in Poland because the conditions for exemptions from CIT under Article 6(1) point 10a of CITA are not completely satisfied. ${ }^{134}$ This position, however, was very recently rejected by the Supreme Administrative Court (SAC) in its judgment of 24 July 2015. ${ }^{135}$ The SAC decided that a Cypriot AIF (PICIS) was similar to any Polish investment fund subjectively exempted from taxation and that its income, derived via Polish tax-transparent (before 1 January 2014) partnerships limited by shares, was not subject to CIT in Poland.

Other directors refused to provide tax abolition relief arguing that the income received by Polish individuals via a Cypriot PE did not derive from a non-agricultural economic

\footnotetext{
${ }^{129}$ See Taliotis (2015), p. 25.

130 See Art. $27 \mathrm{~g}$ PITA.

${ }^{131}$ See Art. $27 \mathrm{~g}(2)$ PITA. For examples of the calculation of the tax abolition relief see in Bartosiewicz and Kubacki (2015), marg. n. 15.

${ }^{132}$ By implementing effective CFC rules, GAAR, exit taxation, and an anti-abuse of investment funds clause, for example.

${ }^{133}$ See advance tax rulings issued by DTCh in Poznań of 10 May 2013 and DTCh in Warsaw of 11 July 2013.

${ }^{134}$ See advance tax rulings issued by DTCh in Warsaw of 24 February 2012 and of 7 July 2012.

135 See SAC's judgement of 24 July 2015.
} 
activity under Polish tax law but from financial capital (e.g. divided, capital gains etc.) ${ }^{136}$ There is also the argument that the qualification of income as business profits under Article 7 of the Poland-Cyprus tax treaty cannot be binding for the purpose of applying the Polish domestic tax law and therefore providing tax abolition relief. The tax authorities have not been challenged on this count by taxpayers before the courts. On the one hand, it seems that the considerable risk of losing the case convinced taxpayers to drop the scheme rather than try to defend its probity before the court. On the other hand, the most recent individual tax rulings confirm the positions of Polish taxpayers that income derived by them via a Cypriot LP, which merely participates passively in profits of other companies, qualifies for the tax abolition relief. ${ }^{137}$ This implies that the scheme may be in force and brings desired tax effects for the Polish taxpayers.

In my view, the Polish tax authorities could have achieved the same result by simply concluding that the Cypriot LP did not constitute a PE for the Polish individual since it was not carrying on a business activity as required by the autonomous tax treaty. ${ }^{138}$ On this basis, its income cannot be considered as business income under Article 7(7) in conjunction with Article 10(4) of the Poland-Cyprus tax treaty but remains dividend income under Article 10(1) of the treaty. Neither therefore does its income qualify for tax abolition relief. However, due to the lack of appropriate anti-avoidance provisions, such as CFC rules, the Polish tax authorities attempted to use various, and in my view inappropriate, interpretative means to prevent Polish taxpayers from successfully exploiting the blatant CFC tax avoidance scheme they had earlier accepted. Had the Polish tax authorities appropriately interpreted the notion of PE under the Poland-Cypriot tax treaty, there would be no issue with the scheme at all. It is not necessary to invoke anti-avoidance provisions to achieve this.

Due to the amendments in Polish tax law, in particular in relation to taxation of investment funds, ${ }^{139}$ the scheme analysed above and illustrated below does not allow for avoidance of taxation on income derived via a tax transparent partnership from 1 January 2017. It means that taxation on business income originally generated in Poland cannot be currently avoided. However, this scheme could have been used for such purpose until 31

\footnotetext{
${ }^{136}$ See advance tax ruling issued by DTCh in Łódź of 19 December 2013.

${ }^{137}$ See for instance advance tax ruling issued by DTCh in Warsaw of 29 March 2016.

${ }^{138}$ Considering the relevant literature, it is correct to assume that LP may constitute a PE of its Polish limited partner in light of the equivalent of Article 7 OECD MTC under Poland-LP tax treaty if the LP carries on an independent income-generating activity of sufficient permanency to qualify as a PE and this activity does not involve merely the passive management of assets, see Rust (2011), p. 103; Reimer (2014), p. 40. Cf. Baker (2014), 5B.07 and 5B.12.

${ }^{139}$ See supra footnote 126.
} 
December 2016. The scheme still allows for the indefinite deferral of tax on income derived via a Cypriot CFC.

Figure II: "Double Cypriot Olive with a Polish Potato": Total tax avoidance of Polish sourced income

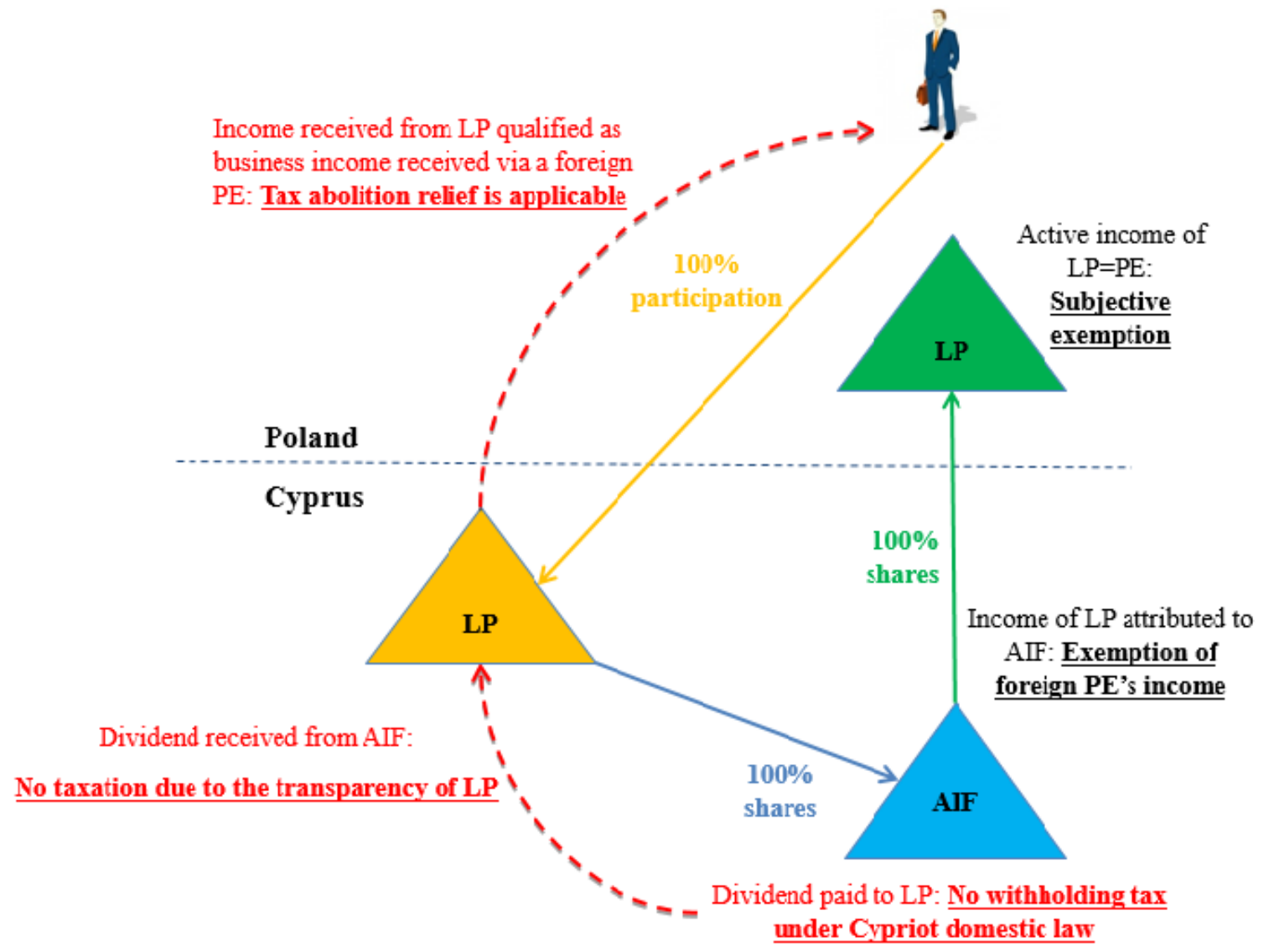

3.3.2.2 The "Luxembourg CFC Scheme": total tax avoidance of income generated in Poland on an ongoing basis by an individual

The procedure and the tax-related consequences of setting up this CFC scheme, which involved the establishment of an investment fund in Luxembourg and exchange of its shares for the rights and duties of the Polish LP, is analogous to that described immediately above in subsection 3.3.2.1 concerning the Cypriot AIF.

The Luxembourg Investment Fund (Lux. Inv. Fund) participates in almost 100 per cent of the rights and duties of the Polish LP involved in an active business activity in Poland. The Polish LP constitutes a foreign PE for the Lux. Inv. Fund. The income generated by the Polish LP is exempt from taxation in Poland (state of source) as well as in Luxembourg (state of residence). The former is based on the subjective exemption from CIT in Poland of collective investment funds with a registered office in an EU member state, i.e., 
Luxembourg. ${ }^{140}$ As a result, all types of income generated by the Polish LP are exempted from taxation in Poland. Neither is this income taxed in Luxembourg, since the Lux. Inv. Fund is subjectively exempted from income tax in that state so that its profits, derived via a PE in Poland (the Polish LP), are not taxed in Luxembourg.

There is no income tax on dividends paid by the Lux. Inv. Fund to the Polish taxpayer (individual) because dividends paid by the Lux. Inv. Fund are exempt from withholding tax. ${ }^{141}$ Such dividends were exempted from taxation in Poland under Article 24(1)(a) of the Polish-Luxembourg tax treaty until the end of 2013. Double non-taxation of dividends paid by the Lux. Inv. Fund to its Polish shareholders has not been possible since 1 January 2014 due to the amendment in the Polish-Luxembourg tax treaty; the exemption method with regard to dividends was replaced by the credit method.

The result of this CFC scheme is that neither the income from current business activity generated in Poland nor the one from its repatriation from Luxembourg to Poland were taxed until 31 December 2013. These consequences of the CFC tax avoidance schemes with the Luxembourg CFC were sanctioned by many advance tax rulings, ${ }^{142}$ which explains why the majority of the FDIs by Polish investors was realized in Luxembourg in the years 2000 2013. ${ }^{143}$ This scheme still allows for the indefinite deferral of tax on income derived via a Luxembourgish CFC but not on income sourced in Poland and derived by the CFC via a Polish tax transparent partnership. ${ }^{144}$

\footnotetext{
${ }^{140}$ See Article 6(1) point 10a of CIT Act. See, however, supra footnote 125 which explains the lack of such exemption from 1 January 2017.

${ }^{141}$ See Estageri (2015), p. 58

${ }^{142}$ See for instance: the advance tax ruling issued by DTCh in Poznań of 27 December 2012; DTCh in Warsaw of 3 February 2011; DTCh in Warsaw of 19 November 2009; and DTCh in Poznań of 21 October 2008.

${ }^{143}$ See supra 3.3.1.

144 This has become impossible since 1 January 2017. See supra footnote 126.
} 
Figure III: "Luxembourg CFC Scheme": total tax avoidance of income generated in Poland on an ongoing basis

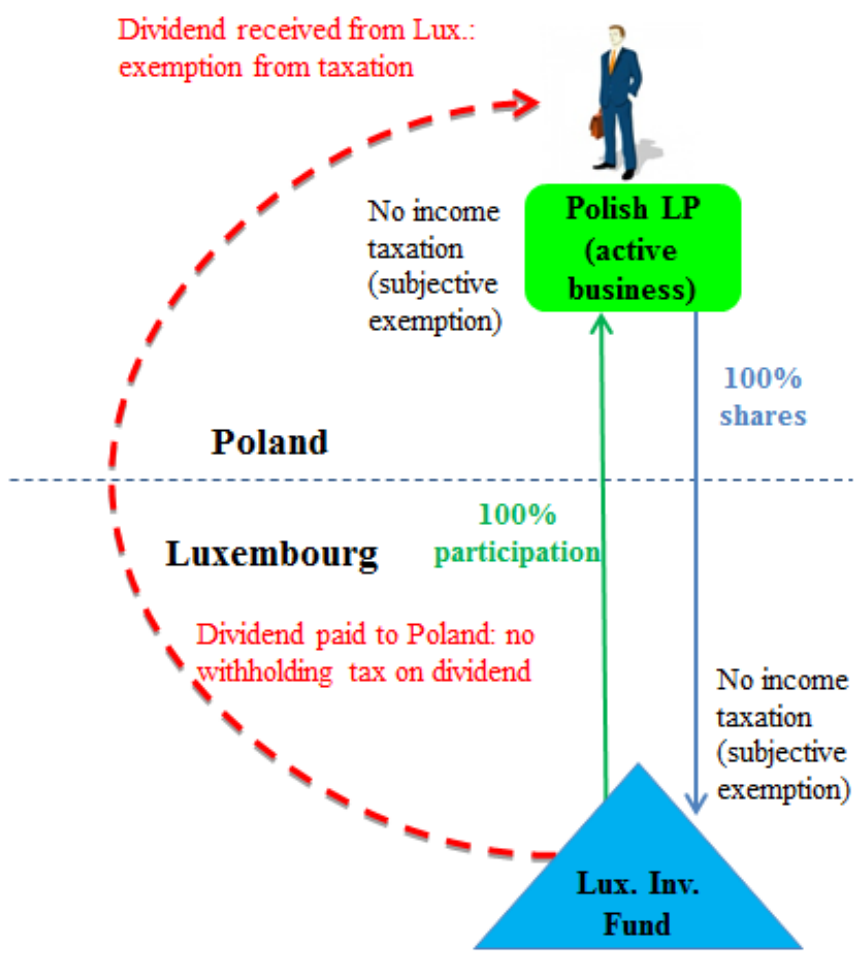

\subsubsection{3 "LPP Scheme": Tax avoidance on income from royalties and director fees}

The following scheme was used by Poland's biggest clothing company, LPP (LPP). ${ }^{145}$ The scheme serves primarily to avoid taxation on royalties received from the licensing of trademarks and director fees. The following explains the steps that were taken in order to establish the scheme and the consequences to the taxpayer of its exploitation.

1. In 2011, LPP, a joint-stock company with tax residence in Poland, the Cypriot Gothals, contributed in kind to the ownership of two trademarks with a value of PLN 556 million (EUR 133.5 million). As a result of this transaction, LPP received nearly 100 per cent of the shares in Gothals and Gothals received ownership of the trademarks. This transaction did not trigger taxation in Poland. ${ }^{146}$

145 See data retrieved online at: http://100najbogatszychpolakow.forbes.pl/ranking-najbogatsi-polacy-
$2012 /$ marek-piechocki,24296,1. The Chief Executive Officer of LPP, Marek Piechocki, was classified by Forbes
in 2013 as the thirteenth richest Pole with private assets of PLN 670 million, see data retrieved online at:
http://100najbogatszychpolakow.forbes.pl/100-najbogatszych-polakow-2013, ranking,139159,1,2.html.
146 Pursuant to Article 13(4) of the Poland-Cyprus tax treaty, an income from alienation of ownership of
trademarks (in-kind contribution) of a Polish company to a Cypriot company will be taxable only in Poland (the
residence state of an alienator). According to Polish tax law, no taxable income appears if the shares of the
Cypriot company are acquired as a result of the in-kind contribution of the trademarks owned by the Polish
company up to the amount of the nominal value of shares of the Cypriot company. The part of the increase in the
value of the contributed trademarks of the Polish company above the acquired nominal value of the shares of the
Cypriot company will be allocated to the supplementary (reserve) capital of the Cypriot company. In this case, 
2. The day after this transaction, Gothals transferred ownership of these trademarks to a Dubai company, Jaradi, in the form of an in-kind contribution. This transaction did not bring about taxation either. ${ }^{147}$ The result of these transactions was that LPP received a nearly 100 per cent share of Jaradi, while Jaradi Limited received a nearly 100 per cent share of Gothals. LPP, in other words, controlled both companies fully. It should be noted here that this transaction and the transaction indicated in point 1 above were repeated in 2013 with respect to LPP's three trademarks with a value of PLN 510 million (EUR 122.5 million).

3. Next, Gothals entered into a licensing agreement with Jaradi, which authorized Gothals to sublicense the trademarks to third parties. Royalties paid by Gothals to Jaradi are not subject to withholding tax in Cyprus because they are exempted from taxation under Article 13(3) of the Cyprus-UAE tax treaty. Moreover, the royalties paid by Gothals to Jaradi constituted deductible expenses for Gothals, and were consequently deducted from the tax base of that company. Owing to the low effective tax rate in Cyprus on income obtained from the exploitation of trademarks (about 2 per cent $)^{148}$ together with the low taxable base due to the level of deductible expenses, income received by Gothals is not taxed in Cyprus.

4. Further, LPP entered into sublicensing agreement with Gothals, entitling LPP to use the trademarks in order to conduct its business, mainly the promotion and sale of clothing in Poland, the Czech Republic, Slovakia, Hungary, Lithuania, Latvia, Estonia, Ukraine, Russia, Romania, and Bulgaria. Consonant with the sublicensing agreement, the royalties paid by LPP to Gothals are tax exempt in both countries due to the provisions of the EU Directive on Interest \& Royalties (2003/49). ${ }^{149}$ The amount of

\footnotetext{
the most likely taxable costs will be equal to the revenue, and thus no taxable income appears (nil tax base). See Article 12(1) point 7 in conjunction with Article 15(1j) point 1 CITA. In the worst case scenario, the nominal value of the acquired shares of Gothals will be taxed, but is likely to be minimal in monetary value. This transaction, however, may not be tax neutral due to the amendments in law as explained by me supra in footnote 125.

${ }^{147}$ Pursuant to Article 13(4) Cyprus-UAE tax treaty, capital gains from transfer of trademarks are taxable only in Cyprus. Under the Cypriot tax law, capital gains from such transactions are exempt from taxation in Cyprus, see Taliotis (2015), pp. 22-23. An income received by Jaradi Limited is not taxable due to the tax-exempt status of this company.

${ }^{148}$ See Neocleous and Aristotelous (2013).

${ }^{149}$ Polish tax laws providing tax exemption on interest and royalties under this directive is included in Article 21(3) CITA. The payments of royalties by LPP to Gothals may not be exempt from tax in Poland after 1 January 2017 due to the introduction of the "beneficial owner" limitation (see the new Article 21(3) point 4 in conjunction with Article 26 (1) CITA) regarding such exemption. Gothals would most likely not fall within the definition of "beneficial owner" under Article 4a(1) point 29 CITA.
} 
royalties paid by LPP to Gothals constitutes tax deductible costs for LPP. ${ }^{150}$ Hence, these royalties decrease the tax base of LPP in Poland in relation to its worldwide income that is taxable in that country.

5. Income derived by Jaradi from royalties received from Cyprus is not taxed in Dubai, since ZEA adopted the territorial tax system whereby foreign-sourced business income, capital gains, dividends, interest and royalties are not taxed in Dubai. ${ }^{151}$ In this context, it is important to note that royalties are taxed neither at source in Poland nor in Cyprus, because tax paid at source could not be deducted from the tax payable in Dubai (no income tax in Dubai = no deduction of tax paid abroad).

6. Because the CEO of LPP, Marek Piechocki, is the director of Jaradi Limited, the significant proportion of the income derived by Jaradi Limited is repatriated to Poland in the form director fees, none of which is taxed in Dubai in relation to individuals (either residents or non-residents) under UEA domestic tax law, ${ }^{152}$ nor in Poland under Article 19 of the Poland-UEA tax treaty. ${ }^{153}$

7. Since LPP fully controls Jaradi and Gothals, it decides when and how much of the income accumulated by these companies will be distributed. LPP may decide that the income accumulated by Jaradi Limited will not be distributed in Poland for many years, which amounts in reality to an unlimited tax deferral. If dividends were paid from Jaradi to LPP, they would be taxed in Poland. This is the reason why the company entitled to receive dividends from Jaradi in the first place is Gothals, and not LPP. In this way, the profits accumulated by Jaradi are distributed to Polish participants without taxation: the dividends paid by Jaradi to Gothals are neither taxed in Dubai nor in Cyprus under their respective domestic laws. ${ }^{154}$ The outcome is that dividends paid by Gothals to LPP are exempt from taxation in both Poland and Cyprus in accordance with the provisions of the Parent-Subsidiary Directive (2011/96). ${ }^{155}$

\footnotetext{
${ }^{150}$ See Article 15(1) CITA.

${ }^{151}$ See Gueydi (2015), p. 17.

152 Id., p. 6.

${ }^{153}$ It is noteworthy that the exemption from taxation applied in Poland to director fees paid from the UEA to Polish directors came to an end by the end of 2015. This stems from the amendment made to the Poland-UAE tax treaty through the addition of a protocol. According to the new Article 19 of this tax treaty, director fees shall be taxed only in the state of residence of the director.

154 There are no withholding taxes in the UAE, see Gueydi (2015), p. 18. In Cyprus any dividends received, including foreign dividends, are exempt from CIT and, in general, also from the special defence contribution. See Taliotis (2015), p. 42.

${ }^{155}$ In the Polish tax law, the provision implementing the exemption under this Directive is Article 22(4) CITA.
} 
As far as I know, the "LPP Scheme" has been, at least implicitly, accepted by tax authorities ${ }^{156}$ and I was unable to find any publicly available material indicating otherwise. Interestingly, LPP spokesman stated in May 2015 that from 1 January 2015, LPP would be attributing income from Gothals under the Polish CFC rules. ${ }^{157}$ Whether LPP did pay tax on Gothals' income because of the application of Polish CFC rules, I was unable to determine.

Figure IV: "LPP Scheme": Tax avoidance on income from royalties and director fees

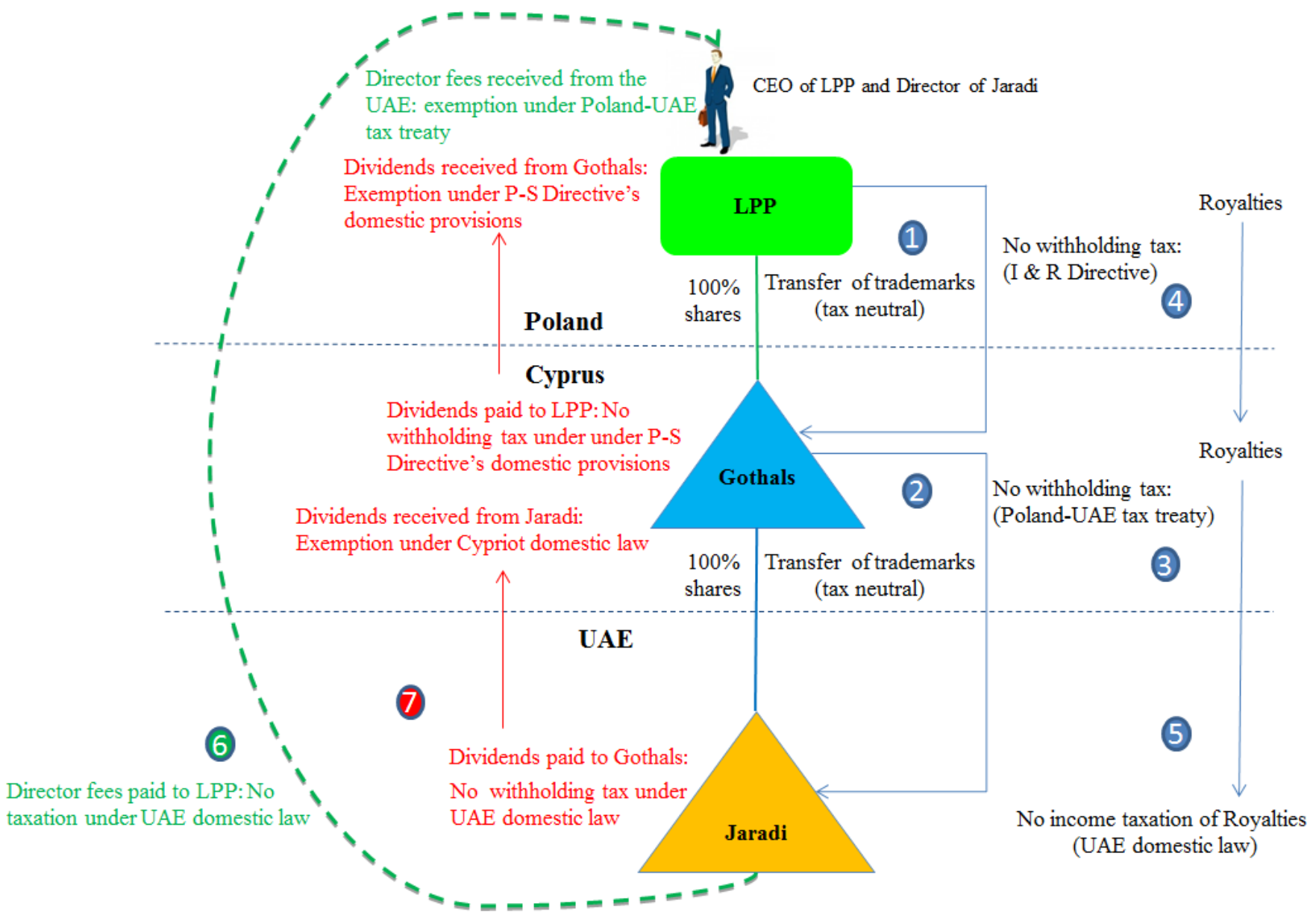

\footnotetext{
${ }^{156}$ That is to say, insofar as advance tax rulings do not give the real names of applicants it is impossible to say exactly whether they accepted the LPP scheme. The following advance tax rulings, however, do appear to condone elements of a structure that corresponds to the LPP scheme. The rulings were handed down, moreover, when most of the planning and implementation of the LPP scheme took place. See DTCh in Poznan of 14 August 2013; DTCh in Warsaw of 21 January 2013 and of 4 July 2013; and DTCh in Bydgoszcz of 30 October 2012.
}

${ }^{157}$ See Brodziak (2015). 


\subsection{Interim conclusions}

The preceding analysis of data and schemes with respect to Poland and the wider world shows the degree to which investments are made for the purpose of avoiding taxation. Polish taxpayers are clearly prolific users of these tax avoidance schemes. The schemes depicted above tend to rely on companies functioning as base and conduit companies, ${ }^{158}$ and it is the combined effect of transactions between them that allows the participants to avoid paying tax. ${ }^{159}$ But the opportunity to avoid tax also stems from the combination of preferential rules in force in the domestic tax laws of the companies' states' of establishment, the domestic tax law of the participants' state, a lack of harmonization and loopholes in the laws. Over and above this, tax treaties and EU/EEA law play an important role in facilitating tax avoidance.

With regard to tax avoidance in Poland, the following conclusions may be drawn:

First, most of the income from FDIs undertaken by Polish investors over the last ten years was derived via CFCs in low-tax EU jurisdictions, such as Luxembourg and Cyprus. ${ }^{160}$ This implies that the majority of Polish FDIs undertaken within the EU over the last ten years have been solely or mainly driven by tax-avoidance purposes rather than economic motives.

Second, in most of the schemes, Polish taxpayers have deliberately avoided taxation on income generated by businesses operating in Poland. Such income is first generated by Polish LPs and directly attributed to CFCs acting as their limited partners with an almost 100 per cent right to participate in the LPs' profits. From the relevant tax treaties' point of view, the LPs constituted PEs of CFCs, the consequences being the attribution of taxing rights on the profits of the LP to Poland, and exemption from taxation of this income in the CFC's residence state. As a result, the effective tax rate on this income was almost nil, not the nominal tax rate of 19 per cent applicable to income derived by companies ${ }^{161}$ or individuals running businesses. ${ }^{162}$

Third, Polish taxpayers, as individuals, will usually be direct participants in CFCs. This is a peculiar feature of the Polish CFC tax avoidance schemes, one that rarely occurs in schemes in other states. ${ }^{163}$ That is to say, internationally the use of CFC schemes leads to tax deferral at the level of the companies controlling CFCs, while in Poland it leads to total tax avoidance at the level of the individuals controlling CFCs. In this case, the individuals

\footnotetext{
${ }^{158}$ See more on tax avoidance with the use of base and conduit companies in OECD (1986) and (1986a) and more recently in De Broe (2008), pp. 5-65.

${ }^{159}$ See Piccioto (1992), pp. 137-139. More recently see Fuest et al. (2013), pp. 310-314.

${ }^{160}$ See supra sections 3.3.1 and 3.3.2.

161 Art. 19(1) CITA.

162 Art. 30c(1) PITA.

${ }^{163}$ Cf. Helminen (1999), p. 207, note 56 in fine; Dahlberg and Wiman (2013), pp. 21-22.
} 
operated through PEs in Poland, which were taxed at the level of the head office (partners in the Polish $\mathrm{LP}=\mathrm{PE}$ ). The head office in the cases $\mathrm{I}$ have explored was an EU (Cypriot/Luxembourg) investment fund, which was subjectively exempted from taxation in Poland. ${ }^{164}$ The reason the investment funds are channelled into Cyprus and Luxembourg rather than Poland is to repatriate income derived by them to Poland without taxation in Poland thanks either to exemptions under tax treaties between Poland and Cyprus and Luxembourg or to abolition relief deriving from the re-classification of income from dividend to business profits. Had these funds been established in Poland, the income would have been taxed at the level of its beneficiaries at the time of its distribution to them.

All in all, in the cases we studied, there was no taxation with regard to (i) income generated in Poland on a current basis from business activities run in Poland; (ii) income transferred and retained by a CFC or another company (iii); and income repatriated to the Polish controlling participants. In this sense, the Polish CFC tax avoidance practices differ markedly from mainstream schemes elsewhere in which companies normally benefit from tax avoidance through long-term tax deferrals. ${ }^{165}$

In some cases the income that was not taxed in Poland at all or only minimally was entirely generated in Poland, through the use of Polish infrastructures and state-financed services. Insofar as states whose infrastructure and services have been used to generate income should also partake of the taxes therefrom, ${ }^{166}$ this type of free-riding is clearly unacceptable. But it reveals the complete powerlessness of Poland to act against CFC tax avoidance in recent years.

This state of affairs, and in particular the divergence between the outcomes of Polish CFC tax avoidance practices (total tax avoidance on an income originally generated in Poland) and mainstream schemes (long-term tax deferrals), will most likely be brought to an end as a result of the recent anti-avoidance rules that have been introduced in the Polish tax law. ${ }^{167}$

To sum up: The significant increase in the value of FDIs related to CFC tax avoidance started in 2004, after Poland's accession to the EU. Since then Polish investors have been able to enjoy freedom of establishment within the EU and free movement of capital without territorial limitations, both of which are important for FDIs via CFCs. In that regard, the Polish case study shows that the EU indeed equips Poland with a legal tool that enhances

\footnotetext{
${ }^{164}$ See supra 3.3.2 and appendix.

165 See Dahlberg and Wiman (2013), pp. 21-22.

${ }^{166}$ See OECD (2013), p. 35; Valta (2013), pp. 5-6; Graetz and O’Hear (1997), pp. 1076-1077.

167 This specifically regards the taxation of investment funds in relation to an income derived via tax transparent partnerships and the implementation of CFC rules.
} 
FDIs, but at the same time fails to prevent tax avoidance in the process - fails to impose the implementation of effective CFC rules in Poland within the legal framework of EU law, due to the legal constraints set up by the concept of wholly artificial arrangement. Thus, one may say that optimal allocation of resources within the EU, as it is required under the functioning of internal market, is by no means ensured under EU law.

The next part of the article therefore focuses on an analysis of the tolerance or even encouragement of tax avoidance under EU law as well as the concept of abuse of EU law in tax cases. This analysis will lead to a plea for a purposive interpretation of "wholly artificial arrangements" in favor of the internal market in order to effectively prevent CFC tax avoidance within the EU under CFC rules at the current stage of the development of the EU.

\section{Tax avoidance and EU law: Legal analysis}

\subsection{Tax avoidance under freedom of establishment}

The analysis in the above sections allows us to presume that the combination of MNEs' financial capacity and managerial ingenuity in running their international businesses with the relative degree of freedom guaranteed by the domestic laws of some EU Member States, such as the Netherlands, Luxembourg, Cyprus and Ireland, and EU law, makes it possible for an enormous amount of income to enter and leave the EU territory without taxation or with only marginal effective taxation. Consequently the question is: does EU law, to some extent, allow for tax avoidance? I will answer this question by analysing the influence of the freedom of establishment on tax avoidance in the eyes of CJEU and Advocate Generals (AGs).

\subsubsection{Company law in the case law of the CJEU and its effect on tax avoidance under EU law}

According to Art. 49 TFEU that governs freedom of establishment,

Within the framework of the provisions set out below, restrictions on the freedom of establishment of nationals of a Member State in the territory of another Member State shall be prohibited. Such prohibition shall also apply to restrictions on the setting-up of agencies, branches or subsidiaries by nationals of any Member State established in the territory of any Member State.

In light of Art. 49 TFEU, CJEU already stated in its judgment in the Centros case that

The right to form a company in accordance with the law of a Member State and to set up branches in other Member States is inherent in the exercise, in a single market, of the freedom of establishment guaranteed by the Treaty. ${ }^{168}$ [Emphasis added]

\footnotetext{
${ }^{168} \mathrm{C}-212 / 97$, paragraph 27.
} 
This means that the purpose of the freedom of establishment does not limit the choice of establishing a company in a Member State, since it is inherent in the enjoyment of this freedom. Taxpayers may do so for whatever reason, including tax avoidance, and it will be in line with the purpose of the freedom of establishment insofar as it does not contradict this purpose. ${ }^{169}$ This stems from the CJEU case law and can be found in addition to the Centros ${ }^{170}$ in its judgments in cases such as Segers, ${ }^{171}$ Inspire Act, ${ }^{172}$ and Überseering. ${ }^{173}$

This case law of the CJEU regarding company law strongly influenced the reasoning of the CJEU in tax avoidance cases which implies that "normal" tax avoidance ${ }^{174}$ is permissible under EU law. For instance, in the landmark Cadbury Schweppes case, the CJEU stated, in paragraphs $36-38$ and $50^{175}$ and in reference to a previous case, that:

However, the fact that a Community national, whether a natural or a legal person, sought to profit from tax advantages in force in a Member State other than his State of residence cannot in itself deprive him of the right to rely on the provisions of the Treaty (see, to that effect, Case C-364/01 Barbier [2003] ECR I-15013, paragraph 71).

As to freedom of establishment, the Court has already held that the fact that the company was established in a Member State for the purpose of benefiting from more favourable legislation does not in itself suffice to constitute abuse of that freedom (see, to that effect, Centros, paragraph 27, and Case C-167/01 Inspire Art [2003] ECR I-10155, paragraph 96).

As noted by the applicants in the main proceedings and the Belgian Government, and by the Cypriot Government at the hearing, it follows that the fact that in this case CS decided to establish CSTS in the IFSC ${ }^{176}$ for the avowed purpose of benefiting from the favourable tax regime which that establishment enjoys does not in itself constitute abuse. That fact does not therefore preclude reliance by CS on Articles $43 \mathrm{EC}$ and $48 \mathrm{EC}$ (see, to that effect, Centros, paragraph 18, and Inspire Art, paragraph 98).

It is also apparent from case-law that the mere fact that a resident company establishes a secondary establishment, such as a subsidiary, in another Member State cannot set up a general presumption of tax evasion and justify a measure which compromises the exercise of a fundamental freedom guaranteed by the Treaty (see, to that effect, ICI, paragraph 26; Case C478/98 Commission v Belgium [2000] ECR I-7587, paragraph 45; $X$ and $Y$, paragraph 62; and Case C-334/02 Commission v France [2004] ECR I-2229, paragraph 27).

All this suggests that seeking for the most favoured tax route by taxpayers is permissible under EU law even if it may be perceived as tax avoidance from the perspective

\footnotetext{
${ }^{169}$ See infra 4.1.2 and 4.2. Cf. 4.3.

${ }^{170} \mathrm{C}-212 / 97$, paragraph 17.

${ }^{171} \mathrm{C}-79 / 85$.

${ }^{172}$ C-167/01, paragraph 139. Cf. AG Tizzano in his opinion of 31 January 2002 about the Open Skies case, C466/98, paragraph 124 .

${ }^{173}$ C-208/00, paragraphs 93-94.

${ }^{174}$ Cf. supra 2.4 .

${ }^{175}$ Cf. AG P. Léger's opinion delivered on 2 May 2006 in the Cadbury Schweppes case, paragraphs 103, 115, 116,144 , and 148 .

176 The used abbreviations stand for: CS - Cadbury Schweppes plc; CSTS - Cadbury Schweppes Treasury Services; the IFSC - the International Financial Services Center in Dublin (Ireland).
} 
of the domestic law of Member States. This explains the existence of tax avoidance schemes within the EU law, as indicated and discussed in sections 3.2.2 and 3.3.2 above. However, the question is: does not EU law impose any limits on tax avoidance?

\subsubsection{Limited effect of company law case law of CJEU on tax avoidance cases: "normal" tax avoidance is permissible under EU law, while "qualified" (=wholly artificial) tax avoidance is not}

Even if what has been said above about the CJEU case law in company law cases, implies that tax avoidance is tolerated under EU law, this tolerance has its limit. This limit, in my view, follows from the limited influence of CJEU case law/company law on tax cases and therefore the case law cannot be automatically transposed to tax case law.

By referring to its previous case law, ${ }^{177}$ in paragraph 55 of its judgment in the Cadbury Schweppes case, the CJEU concluded that the restriction of the freedom of establishment entailed by applying the UK CFC rules may be justified if they apply only "to wholly artificial arrangements which do not reflect economic reality, with a view to escaping the tax normally due on the profits generated by activities carried out on national territory". ${ }^{178}$

In the light of the above, it seems that the CJEU distinguishes between two types of tax avoidance: (i) in a wide sense, the taxpayer tries to escape the tax normally due on the profits generated by activities carried out on national territory ("normal" tax avoidance) and (ii) in a narrow sense, the same taxpayer resorts to wholly artificial arrangements ("qualified" tax avoidance).

The current discussion allows to say that the concept of wholly artificial arrangements is used by the CJEU for creating a ban on tax avoidance at the national level that is unacceptable at the EU level. That is to say, it seems that the CJEU is concerned about whether there is a real establishment in a Member State hosting a CFC from an abuse of EU law perspective. It is noteworthy that the CJEU in its quite recent judgment of 12 June 2014 in joined cases C-39/13, C-40/13 and C-41/13 SCA stated that:

it is settled case-law that that ground [the risk of tax avoidance] does not constitute, by itself, an autonomous justification for a tax restriction on freedom of establishment if it is not relied on in conjunction with a specific objective of combatting wholly artificial arrangements which do not reflect economic reality and the purpose of which is to escape the tax normally due. ${ }^{179}$

\footnotetext{
${ }^{177}$ See C-264/96, paragraph 26; C-324/00, paragraph 37; C-9/02, paragraph 50 and C-446/03, paragraph 57.

${ }^{178}$ See C-196/04, paragraph 55.

${ }^{179}$ Not yet published, paragraph 42.
} 
AG J. Kokott in her opinion delivered on 12 September 2006 in the case $O y A A(\mathrm{C}-231 / 05)$ stated in the same vein that:

prevention of this form of 'tax avoidance' is not a separate ground of justification which can justify a restriction on freedom of establishment. The fact that undertakings seek to profit from the differences between national tax systems is a legitimate form of economic conduct, and is indeed inevitable in an internal market in which taxation of corporations is not harmonised. Accordingly, an undertaking cannot simply be prevented from moving its seat to another Member State which offers more favourable conditions of taxation. ${ }^{180}$

This means that combating tax avoidance only with the use of wholly artificial arrangements constitutes an autonomous justification for a tax restriction on fundamental freedoms triggered by anti-tax avoidance rules by Member States. Whereas counteracting a tax avoidance is not such a justification. To put it differently, tax avoidance is permissible under EU law, while tax avoidance via wholly artificial arrangement is not.

Furthermore, in its judgment in the Cadbury Schweppes case, the CJEU stated that a CFC reflects economic reality if its incorporation corresponds to "an actual establishment intended to carry on genuine economic activities in the host member state" (paragraphs 65-66). However, it is argued in the doctrine and is evident from settled case law, that this statement should not be understood narrowly. ${ }^{181}$ In that respect, and in reference to the CJEU's case law in company law cases such as Segers, ${ }^{182}$ Centros, ${ }^{183}$ and Inspire Act, ${ }^{184}$ Luc de Broe advocates an extremely narrow understanding of the phrase in the Cadbury Schweppes case quoted above. In his view, a company established in one member state as a purely passive investment company, a letter box company or the like, is to be protected under the freedom of establishment insofar as this company has a controlling shareholding in an active subsidiary established in another member state. ${ }^{185}$ Interestingly, this author openly admits that, according to his understanding of the said CJEU case law, residents of non-member states have an opportunity to engage in Directive and treaty shopping. ${ }^{186}$

I do not agree with his opinion due to the following reasons.

\footnotetext{
${ }^{180}$ See paragraph 62 of the opinion. Compare: paragraph 71 of the opinion of AG J. Kokott delivered on 19 November 2009 in the case C-337/08, according to which danger of tax avoidance should not be considered to be a separate ground of justification in addition to the safeguarding of the allocation of the power to impose taxes where it is a question of precluding cross-border profit transfers.

${ }^{181}$ See De Broe (2008), p. 854.

$18279 / 85$.

${ }^{183} \mathrm{C}-212 / 97$, paragraph 17.

${ }^{184} \mathrm{C}-167 / 01$, paragraph 139. See also AG Tizzano in his joined opinion of 31 January 2002 in the Open Skies case, C-466/98, paragraph 124.

${ }^{185}$ See De Broe (2008), p. 859.

${ }^{186}$ Id.
} 
CJEU indeed first confirmed in paragraph 38 of the Cadbury Schweppes case the doctrine stemming from the Segers, Centros and Inspire Act cases, according to which establishing a company in a member state for "the avowed purpose of benefiting from the favourable tax regime which that establishment enjoys does not in itself constitute abuse". It follows from the fact that the purpose pursued by the freedom of establishment does not limit the choice of establishing a company in a member state, since it is inherent in the enjoyment of this freedom. ${ }^{187}$ Its purpose is to assist EU residents in establishing subsidiaries/branches/agencies in other EU member states. This is the definite effect of freedom of establishment on company law case.

By contrast, the said effect (allowing for establishing a company in a member state freely) is not definite in tax law cases. Something more is required to comply with the purpose of the freedom of establishment in such cases in order to avoid the abuse of that freedom. This illustrates paragraph 55 of the Cadbury Schweppes in which it was indicated that a restriction on the freedom of establishment may be "justified on the ground of prevention of abusive practices", i.e. prevention of "the creation of wholly artificial arrangements which do not reflect economic reality, with a view to escaping the tax normally due on the profits generated by activities carried out on national territory". That is to say, the purpose pursued by the freedom of establishment is not to assist taxpayers in avoiding taxation by means of the creation of wholly artificial arrangements in member states which do not reflect economic reality. This constitutes the definite effect of the objective pursued by freedom of establishment on tax law cases.

The effect of the objective pursued by freedom of establishment is thus different in company law cases, on the one hand, and on tax law cases, on the other. As Alexandre Saydé indicates, assessing the purpose of the EU law concerned, for example the purpose of the freedom of establishment, "permits [one] to distinguish cases such as Cadbury Schweppes and Centros, in which artificial cross-border movements are respectively proscribed or ratified."188

Furthermore, in paragraphs 65-66 of the Cadbury Schweppes case, the CJEU made it clear that "the incorporation of a CFC reflects economic reality" - that is to say it should not constitute a wholly artificial arrangement - if that incorporation corresponds "with an actual establishment intended to carry on genuine economic activities in the host Member State".

\footnotetext{
${ }^{187}$ See C-212/97, paragraphs 17 and 27. See also Saydé (2014), pp. 96 and 98; Eidenmüller (2011), p. 137; Barnard and Deakin (2002), p. 395.

${ }^{188}$ See Saydé (2014), p. 93.
} 
In my opinion, it is useful to try and determine the degree at which economic substance/activity is sufficient for being fully protected by the freedom of establishment and with more exactness than under the CJEU in the Cadbury Schweppes or even Fred Olsen cases. ${ }^{189}$ By achieving that degree, I mean the situation in which a CFC scheme enters the legitimate scope of the freedom of establishment and therefore a taxpayer benefiting from that scheme by means of tax avoidance cannot be taxed under CFC rules since such taxation could not be effectively justified by the prevention of wholly artificial arrangements, i.e. would be disproportionate to achieve that aim. In order to determine that degree more precisely, it seems useful to refer to the CJEU case law outside the field of company taxation, in particular to VAT case-law.

Before turning to VAT case-law, I will provide some arguments to justifying my having recourse to it as its use in the analysis of the concept of "economic substance/economic activity" with respect direct taxation provisions (CFC rules) may be questioned. ${ }^{190}$ First, I am not relying on VAT cases solely in order to determine what genuine economic substance or activity mean under the freedom of establishment. Rather, I use such case-law in the context of and in addition to the case-law on direct taxation. Second, as pointed out by AG Jacobs in his opinion on Cassa di Risparmio di Firenze (note 26),

the same concepts in different areas of Community law [now: EU law] should, as a general rule, be given identical meaning, unless otherwise justified by the nature or specific features of the area in which that concept is being inserted and which may warrant an ad hoc reading.

Third, in direct tax cases, the CJEU frequently refers to its previous VAT model of reasoning while examining the compatibility of domestic direct tax law provision with fundamental freedoms as in the Cadbury Schweppes case (paragraph 64). Thirdly, as stated by D. Weber,

there is no reason not to apply the VAT case law when exercising the treaty freedoms. In such a situation, there could also be a transaction that ultimately has, on its own, a nonfiscal goal, but the route to achieve this might have been taken for purely fiscal and artificial reasons. The "essential aim" case law then offers scope to combat this abuse. ${ }^{191}$

${ }^{189}$ As put by D. Smit, "Despite the decisions in Cadbury Schweppes and Fred. Olsen, the degree of economic
"substance" that Member States may require under their CFC rules to the freedom of establishment is still
fraught with uncertainty". See Smit (2014), p. 261 .
${ }^{190}$ The question is whether the CJEU's reasoning in VAT case-law is or can be applicable into the field of direct
taxation, in particular in situations in which the compatibility of domestic direct taxation provisions (e.g. CFC
rules) with treaty freedoms is examined. Cf. Kofler and Tumpel (2009), p. 471; Jiménez (2012), p. 278.
${ }^{191}$ See Weber (2013), p. 256 . Concurring: Smit (2014), p. 261. Contra: De Broe (2008), pp. 859-860; Zalasiński
$(2012)$, pp. $452-453$. Although Zalasiński convincingly argues that the "tax savings motive test is no longer
essential to the new EU concept of direct tax abuse, since it is applicable only to wholly artificial arrangements",
I will not use or refer to this test to determine the degree of genuine economic substance (activity) sufficient
for being fully protected by the freedom of establishment. Moreover, the total ignorance of a tax saving motive
under the EU concept of direct tax abuse does not seem to be correct in light of the CJEU's conclusion in the
Cadbury Schweppes case, since it refers to "wholly artificial arrangements intended to escape the national tax 
With these arguments in mind, I observe that VAT case law allows to distinguish two variants of holding or asset management entities when assessing whether or not they carry on genuine economic activities or have economic substance sufficient for being fully protected under the freedom of establishment. First, some entities merely acquire, hold and dispose of (= for instance, sell) shares of other companies and correspondingly derive income from them, typically in the form of dividends and capital gains. These entities may be considered to not carry on a genuine economic activity or have economic substance enough to be fully protected under the freedom of establishment, since, according to settled case law, "the mere acquisition and holding of shares in a company is not to be regarded as an economic activity", as, for example, "[t]he mere acquisition of financial holdings in other undertakings does not amount to the exploitation of property for the purpose of obtaining income therefrom on a continuing basis because any dividend yielded by that holding is merely the result of ownership of the property." 192 Second, the types of holding or asset management entities which, in addition to their shareholding in other companies, are actively involved in the management of those companies "must be regarded as taking part in the economic activity carried on by the controlled undertaking." 193

Accordingly, the mere shareholding of a CFC in other entities, without an active engagement in other entities in order to gain profits from them, such as managing their resources and carrying risk associated with it, constitutes a strong indicator of the lack of a sufficient degree of genuine business activity/substance at the level of the CFC for being fully protected under the freedom of establishment. ${ }^{194}$ Interestingly, this finding largely converges with the finding stemming from the definition of economic activity under the Polish tax law ${ }^{195}$ and autonomous meaning of the term "business activity" under Article 7 OECD MTC. ${ }^{196}$

In other words, a company (e.g. CFC) established in a member state must carry out a genuine economic activity itself in order to be protected under the freedom of establishment.

normally payable". The fact that the CJEU later says that such intention must be proven "despite the existence of tax motives" does not disregard the importance of proving the intention to avoid taxation. It only means, in context of the whole conclusion, that the intention must be proved on objective rather than subjective factors (the objectified intention), cf. supra 17.1.2.

${ }^{192}$ See C-80/95, paragraph 15. See also C-60/90, paragraph 13; C-333/91, paragraph 12; and C-77/01, paragraph 58.

${ }^{193}$ See C-142/99, paragraph 18 and C-222/04, paragraph 112-113. See also E-3/13 and E-20/13, paragraph 99; Smit (2014), p. 261.

${ }^{194}$ Concurring: Smit (2014), p. 261; Thömmes and Nakhai (2005), p. 79. Contra: De Broe (2008), p. 859.

195 See Article 5a point 6 Personal Income Tax Act (PITA, Ustawa o podatku dochodu od osób fizycznych) and Article 3 point 9 Tax Ordinance (TO, Ordynacja podatkowa) which, in turn, in a part refer in that regard to Article 2 Act on Freedom of Establishment (AFE, Ustawa o swobodzie działalności gospodarczej). See also resolution of Supreme Administrative Court (SAC, Naczelny Sad Administracyjny) of 16 January 2012.

${ }^{196}$ See Rust (2011), pp. 95, 102, 106; Reimer (2014), p. 40; Baker (2014), 5B.07 and 5B.12. 
The evaluation of activities should therefore be done at the level of the company established in a member state, not of its subsidiary or branch. ${ }^{197}$ A fortiori, a company's activities are not considered to be genuine economic activities if they are outsourced to companies in other member states, because, from the perspective of economic activity, it generally makes no sense for a company "to outsource its key entrepreneurial management activities to another party without maintaining control over the risks [and over resources] connected with these activities". 198

In the Segers, Centros and Inspire Act cases, it was evident that the companies were not merely involved in passive investments of other entities in order to avoid taxation, but carried out genuine economic activities as defined by the freedom of establishment, if not in their member states of establishments, then in other member states through their branches or agencies or subsidiaries. ${ }^{199}$ By contrast, in the Cadbury Schweppes case, the companies in question (two CFCs, CSTS and CSTI) were established in Ireland (Dublin) by their parent company resident in the UK (CS), only to take advantage of the Irish tax regime (the International Financial Services Center in Dublin) without any intent to pursue genuine economic activities in Ireland or elsewhere. ${ }^{200}$ Consequently, it was logical and justified, not only on account of various effects of the objective pursued by freedom of establishment mentioned above, but also of facts relating to the Cadbury Schweppes case, that the CJEU did not stop its reasoning with paragraph 38, which reflected the outcome of Segers, Centros and Inspire Act cases (=definite effect of the freedom of establishment on company law cases), but developed it in paragraphs 55-68, which are specifically relevant to tax avoidance cases. Such development did not occur in Segers, Centros and Inspire Act cases, since it was not needed due to various legal questions, effect of the purpose of freedom of establishment and facts than in the Cadbury Schweppes case. In particular, the former case law did not deal with tax avoidance structures, while the latter case did and therefore the outcome of the former case law (company law) cannot have a definite legal effect on cases similar to this in the latter case law (tax law).

The observation above leads us to the concept of abuse of EU law in tax cases which delineates the limit for tax avoidance under EU law. In that regard, the interesting question is whether the concept of abuse of EU law is sufficient to effectively prevent tax avoidance,

\footnotetext{
${ }^{197}$ Concurring: Thömmes and Nakhai (2005), p. 79; Smit (2014), p. 263. See also Kemmeren (2001), pp. 184185. Cite after: Smit (2014), p. 263, footnote 56.

${ }^{198}$ See Smit (2014), p. 265 and this author's reference per analogiam to OECD (2010), paragraph 9.23.

${ }^{199}$ See Thömmes and Nakhai (2005), p. 79; Smit (2014), p. 263.

${ }^{200}$ Id. See C-196/04, paragraph 18 and 38.
} 
which may distort the establishment and development of an internal market, by Member States or at the EU level under the EU. The former case involves the application of domestic anti-avoidance measures, while the latter case involves prospectively introduced EU secondary law, e.g. ATAD.

\subsection{The concept of abuse of EU law in tax cases: tax avoidance via wholly artificial arrangements}

In the Cadbury Schweppes case (paragraph 55) ${ }^{201}$ and in the Commission vs. the UK case (paragraph 25) 202 , the CJEU concluded that the restriction of freedom of establishment and free movement of capital resulting from the application of the contested UK legislation was justified and proportionate if it applied only to "wholly artificial arrangements which do not reflect economic reality, with a view to escaping the tax normally due on the profits generated by activities carried out on national territory." ${ }^{203}$ This means that abuse of EU law in tax avoidance cases exists only if the effects of tax avoidance, such as tax deferral, the reduction of effective tax rates or total tax avoidance, ${ }^{204}$ are achieved via wholly artificial arrangements. $^{205}$

Since the concept of "wholly artificial arrangement" has been developed by the CJEU in direct tax cases in order to prevent abusive practices by taxpayers avoiding income taxation (=concept of abuse of EU law), ${ }^{206,207}$ its every interpretation should oscillate within the concept of the abuse of EU law. The concept of abuse of EU law has been excellently analyzed by Alexandre Saydé, based on relevant CJEU case law.

\footnotetext{
${ }^{201}$ See C-264/96, paragraph 26; C-324/00, paragraph 37; C-9/02, paragraph 50 and C-446/03, paragraph 57.

${ }^{202}$ See 282/12; C-524/04, paragraphs 72 and 74 and C-182/08, paragraph 89.

${ }^{203}$ The restriction of the free movement of capital may also be justified by the need to provide effective fiscal supervision, but his justification is valid insofar as there is no a legal measure for an effective exchange of tax information between the Member State involved and a third state. See C-422/01, paragraph 42; C-80/94, paragraph 26 and C-136/00, paragraph 49. A comprehensive and systematic overview of the relevant CJEU case law in that regard is presented in Hamels (2009), pp. 583-591. What should matter is whether the legal instrument in question is suitable for receiving the information required for the effective application of the domestic tax law provisions, but not its legal nature. See C-190/12, paragraph 105. Cf. Smit (2012), p. 571.

${ }^{204}$ Cf. supra 2.3, 2.4 and infra appendix.

${ }^{205}$ Cf. C-39/13, C-40/13 and C-41/13, paragraph 42.

${ }^{206}$ C-196/04, paragraph 55. See also Poulsen (2013), pp. 230-251; Piantavigna (2011), pp. 134-147; Pistone (2011), p. 381: Zalasiński (2008), pp. 156-167; Lang and Heidenbauer (2008), pp. 587-617; De Broe (2008), pp. 805-816.

${ }^{207}$ In tax avoidance cases, abuse of EU law may occur only "vertically" -private abuse (taxpayer) vs. public (Treasury as a whole) - and in situations in which a taxpayer relies on an EU law norm in order to obtain a tax benefit, usually by avoiding taxation under domestic law and benefiting from low taxation in another member state, contrary to the purpose of the EU norm concerned, see De Broe (2008), p. 159; Saydé (2014), pp. 23-26 and 30. See for example CJEU case law in direct taxation C-311/08, paragraph 57 and C-196/04, paragraph 55.
} 
In particular, I consider Saydé's classification of the elements of the concept of abuse of EU law well-founded. Thus, I will keep that classification in mind during the further analysis of the concept of wholly artificial arrangement under its pro-internal market interpretation. He sees abuse of EU law as consisting of three components. The first is "a gain-seeking choice of law," ${ }^{208}$ which in direct tax law cases concerns attempts to obtain a tax benefit by choosing a preferable tax jurisdiction. ${ }^{209}$ The second is "artificiality" understood as an "economically irrational" gain-seeking choice of law in the sense that this choice, realized via a structure and/or transaction, lacks a genuine economic explanation beyond gaining a benefit stemming from the chosen law, for example by using a CFC in a low-tax EU jurisdiction for the sole purpose of avoiding tax. ${ }^{210}$ The last component concerns the "illegitimacy of artificial choice[s] of law under the teleological assessment" which means that a benefit obtained through an artificial choice of law is not desirable under the EU law in question. ${ }^{211}$ For example, it is against the objective pursued by freedom of establishment for a taxpayer to establish a CFC that is disengaged from genuine economic activities in low-tax EU jurisdiction for the sole purpose of escaping taxation by diverting income to the CFC. ${ }^{212}$

\subsection{Purposive interpretation of "wholly artificial arrangements" in favor of the internal market}

In my view, every interpretation of "wholly artificial arrangements" should be done in favor of the internal market, because the establishing and developing of an internal market constitutes one of the most important purposes of the EU. ${ }^{213}$ This is the reason why a purposive interpretation that contributes to an appropriate functioning of the internal market represents the quintessence of the main canon of interpretation of EU law established by the CJEU case law. ${ }^{214}$ The internal market is clearly the key standard on which the Court builds

\footnotetext{
${ }^{208}$ Saydé explains that this excludes "situations covered by a single legal regime, abuses of rights, detrimental changes of law [e.g. worsening the taxpayer's situation] and involuntarily changes of law”. See Saydé (2014), p. 83.

${ }^{209}$ C-254/96, paragraph 26; C-324/00, paragraph 37; C-9/02, paragraph 50; C-446/03, paragraph 57 and $\mathrm{C}$ 196/04, paragraph 51 .

${ }^{210}$ See Saydé (2014), p. 83 and C-196/04, paragraph 59.

211 See Saydé (2014), pp. 93-98.

${ }^{212} \mathrm{C}-196 / 04$, paragraphs 51, 55 and 64.

${ }^{213}$ Article 3(3) TUE says that the Union shall establish an internal market. See also Kemmeren (2008), pp. 559 and 585; Cordevener (2006), pp. 4-6, 39 and 43.

${ }^{214}$ See 283/81; C-283/94, C-291/94 and C-292/94, paragraphs 24 and 26; C-375/98, paragraphs 22 and 24; C27/07, ECR 2008, paragraph 22; and C-247/08, paragraph 26. See also Helminen (2015), 1.8.1; Monsenego (2012), p. 22; Morawski (2010), pp. 302 and 310; Schön (2008), p. 82; De Hosson (2006), pp. 294-307; Fennelly (1997), p. 667.
} 
its case law, ${ }^{215}$ including its introduction of the concept of "wholly artificial arrangement" within the framework of the wider concept of abuse of EU law. Consequently, I will apply this interpretation below in order to determine the appropriate understanding of the concept of "wholly artificial arrangement".

In its judgments regarding CFC rules, the CJEU used the phrase "prevention of abusive practices" to indicate that they justify a restriction on the freedom of establishment. ${ }^{216}$ In paragraph 64 of its judgment in the Cadbury Schweppes case, the CJEU refers to paragraphs 52-53 of the judgments in the Emsland-Stärke and Halifax cases ${ }^{217}$ and gives a definition of "a wholly artificial arrangement", even though the terms used in those paragraphs were "abuse" and "an abusive practice", and not "wholly artificial arrangement." I agree with Saydé here that the phrase "wholly artificial arrangement" should therefore be understood as "an abusive practice." 218

In paragraph 64 of Cadbury Schweppes, the CJEU pointed out that in order to find whether a "wholly artificial arrangement" exists, "in addition to a subjective element consisting in the intention to obtain a tax advantage, there must be objective circumstances showing that, despite formal observance of the conditions laid down by EU law, the objective pursued by freedom of establishment has not been achieved". This finding makes the judgment in the Cadbury Schweppes case quite difficult to follow insofar as the CJEU actually merged the issue of artificiality with the contradiction of the purpose of freedom of establishment instead of clearly distinguishing between the two and defining first what constitutes a "wholly artificial arrangement" before analysing in what ways the purpose is contradicted. ${ }^{219}$ It also blurs the understanding of the concept of "wholly artificial arrangement."

Furthermore, in paragraph 65, the CJEU stated that whenever "the incorporation of a CFC reflects economic reality," taxation of the CFC's income must be excluded under CFC rules in order to provide for the compatibility of these rules with EU law. If the CJEU's line of argument had stopped there, its case law in company law cases would affect all tax law cases definitely, which, as I showed earlier, ${ }^{220}$ would be inappropriate because the objective pursued by freedom of establishment has a different effect on tax and company law.

\footnotetext{
215 See Kemmeren (2008), p. 560 and 585-586. See supra 1.5.6.2.

${ }^{216}$ C-196/04, paragraph 55 and C-201/05, paragraph 77.

${ }^{217} \mathrm{C}-110 / 99$ and $\mathrm{C}-255 / 02$ respectively.

218 See Saydé (2014), p. 92.

${ }^{219}$ Cf. Karimeri (2011), p. 309; Lang and Heidenbauer (2008), pp. 607-608.

${ }^{220}$ See supra 4.1.2.
} 
For this reason, identifying "wholly artificial arrangement" with "a CFC that does not reflect economic reality" seems to be a mistake. In paragraph 66, the CJEU added that a CFC "must correspond with an actual establishment intended to carry on genuine economic activities in the host Member State," giving examples in paragraph 68 of a 'letterbox' or 'front' subsidiary as a wholly artificial CFC. Even if the CJEU refers to the physical existence of a CFC, i.e. its economic substance and genuine business conduct, in terms of premises, staff, and equipment in paragraph 67, what matters for concluding whether there is a wholly artificial arrangement under CJEU case law or not is the existence of a genuine economic activity carried on by the CFC. ${ }^{221}$ Such activity surely exists when a CFC is actively engaged in a genuine business of its own or in the genuine business of other companies, whereas the existence of such activity is dubious when a CFC merely participates passively in the active business of other companies by way of passive participation in the profits of such companies. ${ }^{222}$ In other words, in the context of CJEU case law on tax law cases, a CFC is to be considered "wholly artificial", not when it does not reflect economic reality, but when it does not reflect economic rationality apart from obtaining tax benefits (=the lack of a genuine economic activity carried on by the CFC). Hence, the "wholly artificial arrangements that do not reflect economic reality" could be understood as "abusive practices that do not reflect economic rationality."223

This interpretation of the concept of "wholly artificial arrangement" gives importance to the concept of abuse of EU law in tax cases. Conversely, a literal understanding of "wholly artificial arrangements that do not reflect economic reality" would lead to the opposite results. In particular, this would reduce the concept of abuse of EU law in tax cases to nil, since almost every structure or transaction reflects an economic reality. ${ }^{224}$ As pointed out by Saydé,

\begin{abstract}
every seminal case of abuse examined in this study involves 'real' economic transactions, but which are wrapped up in an artificial legal cloak. For instance, in Emsland-Stärke, 'real' agricultural goods were dispatched from Germany to Italy and to another location in Germany, but the national judge wondered whether the Swiss stop had any economic rationality, regardless of the export refund claimed. Halifax contracted 'real' independent builders to build 'real' call centers; yet the artificiality test enquired whether the complex transactional structure had any rational explanation beyond its profitable tax consequences. In Thin Cap Group Litigation, 'real' sums of money were transferred from a subsidiary to a parent company; the artificiality test only questioned the economic rationality of the legal cloak elected, namely payment of interest instead of a distribution of a dividend, given its profitable tax consequences. Accordingly, interpreting the artificiality test as an enquiry of
\end{abstract}

\footnotetext{
${ }^{221}$ See C-196/04, paragraph 6 and C-341/04, paragraph 35. See also $\operatorname{COM(2007)} 785$ final, pp. 4-5. In the literature, see Lang (2010), pp. 444-445; Lang and Heidenbauer (2008), pp. 603-604; De Broe (2008), p. 852.

222 See supra 4.1.2.

${ }^{223}$ See Saydé (2014), pp. 90 and 92.

${ }^{224}$ Id., p. 90.
} 
the economic reality of the underlying transactions would filter out paramount cases of abuse as Emsland-Stärke and Halifax. ${ }^{225}$

Likewise considering that "wholly artificial arrangements" are the only arrangements that "do not reflect economic reality" would mean, for example, that the "Double Cypriot Olive with a Polish Potato," 226 the "Double Irish with a Dutch Sandwich," 227 and other similar CFC tax avoidance schemes should be protected under EU law; the question is: what value ought to be protected $?^{228}$

The establishment of the internal market is "meant to ensure optimal allocation of resources within the European Union;" 229 now, blatant CFC tax avoidance schemes may seriously distort such an allocation, since it jeopardizes "balanced allocation between Member States of the power to impose taxes." 230 This means that a literal interpretation of the concept of "wholly artificial arrangement" must be rejected in favour of one that contributes to the fair functioning of the internal market and allows to curb tax avoidance practices under CFC rules that are harmful to the internal market.

Thus, the "wholly artificial arrangements that do not reflect economic reality" should be understood as "abusive practices that do not reflect economic rationality." Such understanding of "wholly artificial arrangements" does not only follow from its pro-internal market purposive interpretation, but it also properly recognizes and gives weight to the real economic and social effects of CJEU case law in tax avoidance cases ${ }^{231}$ while distinguishing between appropriate and inappropriate achievement of the purposes of EU law. ${ }^{232}$

This interpretation of "wholly artificial arrangements" allows me to develop a solution to the problem of designing CFC rules which are both effective in preventing CFC tax avoidance within the framework of EU law and compatible with EU law. I will elaborate on it in the next part of the study.

\footnotetext{
${ }^{225} \mathrm{Id}$.

${ }^{226}$ See supra 3.2.2.

${ }^{227}$ See supra 3.3.2.1.

${ }^{228}$ Cf. Karimeri (2011), p. 315; Weber (2005), pp. 165-166.

${ }^{229}$ See Schön (2008), p. 82. Concurring: Karimeri (2011), p. 314.

${ }^{230}$ See C-196/04, paragraph 56 and C-446/03, paragraph 46.

${ }^{231}$ The interpretation that gives weight to the real economic and social effects of CJEU judgments is enhanced by scholars. See Vanistendael (1997), p. 154; Zalasiński (2009), p. 287.

${ }^{232}$ Cf. Karimeri (2011), p. 315.
} 


\section{Taxation of only "tax avoidance income" under CFC rules as a solution for the problem of CFC tax avoidance within the framework of EU law}

\subsection{Preliminary remarks: References to the critical evaluation of the OECD's recommendations (BEPS Action 3) and the EU Council's (Anti-Tax Avoidance Directive) minimum standards}

In previous publications ${ }^{233}$, I pursued the analysis of the recommendations of the OECD for effective CFC rules in dealing with base erosion and profit shifting (which is the ultimate purpose of Action 3) within EU/EEA ${ }^{234}$ and the minimum standard of CFC rules that legislatures of Member States should comply with according to Article 8 of the Anti-Tax Avoidance Directive ("the EU's CFC rules"). ${ }^{235}$ I will not repeat here this analysis, but just concisely sum up my previous findings, as they will explain why I have decided to develop my own solution to the problem of the prevention of CFC tax avoidance within the EU/EEA legal dimension rather than rely on the OECD's/EU Councils' recommendations/minimum standard only.

The analysis shows that the three recommendations of the OECD - applying CFC rules to both resident and non-resident companies, designing CFC rules to explicitly ensure a balanced allocation of taxing power, and applying CFC rules to transactions that are "partly wholly artificial" - put forward by the OECD under BEPS Action 3 with a view to strengthening Member States' CFC rules in a way that is compatible with EU law do not meet CJEU requirements on the compatibility of CFC rules with EU law on a standalone basis. Only the recommendation which refers to "substance analysis that would only subject taxpayers to CFC rules if the CFCs did not engage in genuine economic activities", can be said to meet the CJEU's requirements insofar as it falls within the ambit of the CJEU's "wholly artificial arrangements" limitation.

Another observation is that the core recommendations to design CFC rules so as to explicitly ensure a balanced allocation of taxing power and apply them only to transactions

\footnotetext{
${ }^{233}$ See Kuźniacki (2015) and (2016).

${ }^{234}$ See OECD (2015a), paragraph 22.

${ }^{235}$ See Articles 3 and 7-8 of the Anti-Tax Avoidance Directive (ATAD) and COM(2016) 24 final, p.12. For the purpose of this paper, "the EU's CFC rules" are understood as a minimum standard for CFC rules set forth in Articles 7 and 8 of the ATAD. The Commission originally proposed as a minimum standard for CFC rules that legislators of Member States take note of Article 8 of the ATAD's proposal of 28 January 2016.
} 
that are "partly wholly artificial", are reflected in the substance analysis. ${ }^{236}$ Hence these recommendations appear to be parts of the substance analysis recommendation rather than separate recommendations. By contrast, the recommendation to cover both resident and nonresident companies does not fall within the ambit of the substance analysis and does not seem to have been promoted by the Commission at all, since Article 7(1)(b) of the Anti-Tax Avoidance Directive implies that the EU's CFC rules can only apply in a cross-border scenario.

Furthermore, taking all of the OECD recommendations in light of the EU's CFC rules concerning the design of CFC rules of Member States makes the rules immensely complex and, due to their unusually narrow scope, reduces their ability to prevent tax avoidance through the use of CFCs by residents of Member States. In that sense, they do not constitute a desired and adequate solution to how member states should design CFC rules that are both effective and compatible with EU law. Instead, they turn CFC rules into ultra-complicated quasi-transfer pricing rules the benchmark of which, i.e. the UK CFC rules, covers over more than 100 A4 pages of legal text and dozens of pages of administrative guidelines.

Consequently, I would like to recommend an alternative solution to the problem of the compatibility between CFC rules and EU law and of strengthening their effectiveness in preventing CFC tax avoidance. The solution aims to apply CFC rules under a combination of entity and transactional approaches ${ }^{237}$ and evolves from an interpretation of the concept of "wholly artificial arrangement" that is in favour of the internal market.

\subsection{The outline of the solution}

In light of the interpretation presented in the section 4.3, a CFC can be said to constitute a wholly artificial arrangement (=a tool for abusive practices that do not reflect economic rationality) when it does not carry out a genuine activity of its own and there is no other rationale for receiving income by the $\mathrm{CFC}$ apart from obtaining tax benefits by its participants. Such income can be considered as "tax avoidance income" and a CFC which functions only or essentially to obtain that income could be seen as a wholly artificial arrangement. Hence, taxation of that income ought to lead to the prevention of tax avoidance via "wholly artificial arrangements" under the understanding attributed to them following a purposive interpretation

\footnotetext{
${ }^{236}$ However, there is room for discussion as to whether ensuring a balanced allocation of taxing power may constitute an autonomous justification on a standalone basis. I disregarded the appropriateness of following such a solution for member states in Kuźniacki (2016), pp. 144-154, however.

${ }^{237}$ Interestingly, the dualistic perspective approach may be put in parallel with the distinction between a marketbased accounting system and an entity-based one, cf. Biondi (2011).
} 
of the legislation in favour of the internal market. Under CJEU case law, ${ }^{238}$ one may also see such taxation as ensuring balanced allocation of taxing rights and preventing tax avoidance.

I recommend therefore that CFC rules should be applied only for the purpose of taxing the income derived by a CFC that can be considered as „tax avoidance income”. This, in my view, would amount to an alternative solution to the problem of the compatibility of CFC rules with EU law while strengthening their effectiveness in preventing CFC tax avoidance.

The solution aims to apply CFC rules under a two-step approach. It is a combination of the entity ("artificial establishment gateway") and transactional ("artificial transaction gateway") approaches. It evolves from an interpretation of the concept of "wholly artificial arrangement" in favour of the internal market and to some extent converges with the OECD's recommendation to apply CFC rules to transactions that are "partly wholly artificial" (or rather, partly artificial arrangements). It also reflects the issue of balanced allocation of taxing rights by allowing authorities to employ the arm's length principle insofar as it is appropriate to determine the artificiality of transactions diverting income to a CFC by its participants. Consequently, the solution lies in the justification of CFC rules under EU law through the prevention of wholly artificial arrangements understood as favouring the internal market, or, through a combination of ensuring a balanced allocation of taxing rights and preventing tax avoidance.

Only if the CFC's profits pass through both gateways as indicated above it may be concluded that it is a case of "tax avoidance income". Only such profits can be attributed to the CFC's controlling taxpayers for the purpose of their taxation under CFC rules. This precise approach to attribution of income seems to comply (by analogy to attribution of income from non-arm's length transactions) with the outcome of CJEU's judgment in Test Claimants in the Thin Cap Group Litigation case. ${ }^{239}$

\section{3 "Artificial establishment gateway"}

Under "artificial establishment gateway", the tax authorities must determine whether or not a CFC carries out a genuine economic activity (the burden of the proof lies with the tax authorities). Guidance on doing so is included in sections 4.1-4.3 above. For instance, it is likely that a CFC does not carry out a genuine economic activity if it restricts its activity to a mere shareholding in other entities, without active engagement in other entities in order to

\footnotetext{
${ }^{238}$ See C-311/08, paragraph 66 and C-231/05, paragraph 63.

${ }^{239}$ C-524/04, paragraph 92.
} 
gain profits from them, and has no personnel of its own but is managed by the personnel of other companies established in countries other than the CFC's residence State.

The lack of a genuine economic activity at the level of a CFC is a condition for taxing the whole of the CFC's income/profits under the "artificial establishment gateway". The justification for taxing the whole of the CFC's income follows here from the fact that the absence of a genuine economic activity at the level of a CFC suggests that the whole of the income has been derived by a CFC from sources of income diverted to it by its participants intended to escape the national tax normally payable.

Just as the scope of the tax liability of a controlling taxpayer under the artificial establishment gateway covers the whole income of the CFC, so the justification for doing so relies on the prevention of the use of the wholly artificial CFC (=the lack of a genuine economic activity at the level of a CFC).

Even if the tax authorities provide evidence that the CFC is artificial, the taxpayer controlling the CFC must be given an opportunity to produce counterevidence without undue administrative constraint. ${ }^{240}$

\section{4 "Artificial transaction gateway"}

If the "artificial establishment gateway" was the only one under which CFC rules apply, the effectiveness of such rules would be illusory. ${ }^{241}$ That is why that gateway must be accompanied with a more sophisticated one - an "artificial transaction gateway".

Under "the artificial transaction gateway", tax authorities may prove that even if a CFC is not wholly artificial as such, part of its income has been derived from sources of income diverted to it by the taxpayers primarily ${ }^{242}$ for tax avoidance purpose. ${ }^{243}$ Spotting

\footnotetext{
${ }^{240}$ See C-311/08, paragraph 71; C-201/05, paragraph 85; C-524/04, paragraph 82; and C-196/04, paragraph 70.

${ }^{241}$ Cf. 4.3.

${ }^{242}$ The reason the word "primarily" is used with respect to the taxpayer's purpose of avoiding tax is that it reflects the balance between the terminology used by the CJEU in that regard, on the one hand (the CJEU uses different words in relation to the purpose of "escaping the tax normally due"/"obtaining a tax advantage", etc. (="tax avoidance"), e.g. "sole" in C-282/12, paragraph 34; C-112/14, paragraph 25; "sole" and "essential" interchangeably in C-255/02, paragraphs 59-60, 69, 75, and 86; "principal" in C-425/06; "predominant" in C126/10, paragraph 35), and the feasibility of determining "tax avoidance income" under EU law by tax authorities, on the other (using the word "sole" in relation to the taxpayer's purpose to avoid taxation should be rejected, because it would virtually make it impossible for tax authorities to establish such a "sole purpose", even in relatively obvious tax avoidance cases that are likely to go beyond the scope of the fundamental freedoms and distort the pivotal function of the EU, i.e. to establish and maintain the internal market). Cf. with respect to tax treaties Furuseth (2016), p. 115. Most importantly, in the cornerstone judgement on the compatibility of CFC rules with EU law (C-196/04), the CJEU did not use an adverb in relation to the phrase "escaping the tax normally due" (obiter dictum in paragraph 55) or "intended to escape the national tax normally payable" (ratio decidendi paragraph 76). To be precise, in the latter case, the word "only" in the phrase "only to wholly artificial arrangements intended to escape the national tax normally payable" was appended only to "wholly artificial
} 
diversions requires a high level of precision and must focus on objective factors/conditions of the transactions triggering the diversions.

The point is to prove that some transactions are artificial in the sense that they do not entail any substantive commercial or economic advantages related to the acquisition of income by the CFC other than obtaining a tax advantage (=tax avoidance/reduction/deferrals) by the CFC's participants. It must be clear that in conducting artificial transactions, the CFC's participants obtain the tax advantages which considerably outweigh their non-tax (commercial) advantages. Accordingly, the effect of artificial transactions can be either immediate (tax avoidance $=$ double non-taxation) or extended in time (tax deferral); no or little economic substance is created and usually the tax consequences relating to it are not commensurate with the change in the CFC's participants' economic position - this change is, however, noticeable in their tax position. ${ }^{244}$ Evidently, such transactions have no business purpose/effect whatsoever apart from tax avoidance or their purpose/effect is minor in comparison with the tax avoidance purpose/effect.

Real examples of CFC tax avoidance schemes in which CFCs could be considered to derive income from artificial transactions primarily to avoid taxation (= "tax avoidance income") are those described and analyzed in section 3.3.2 above. To refer to a less blatant example here, the "LLP Scheme", one may say that transferring a license to use trademarks (source of income) originally owned by a Polish resident company (LLP) to a Cypriot and then a UAE CFC was motivated primarily to avoid taxation on royalties paid for the use of the said trademarks in Poland and other countries as well so as to totally avoid taxation of director fees at the level of Polish individual (=director of the Polish controlling company and CFCs). The Polish controlling company (LPP) was involved in genuine economic activities while the CFCs were passively participating in profits originally generated by the Polish company by receiving royalties from the Polish company for the license to use trademarks. This means that all transactions led to diversions of income to CFCs primarily for tax avoidance purposes by

arrangements", not "to intended to escape the national tax normally payable". This finds confirmation in the use by the CJEU in other judgements (cf. C-282/12, paragraph 34; C-112/14, paragraph 25), of the word "sole" clearly with respect to the purpose "to avoid the tax normally payable", i.e. "specifically targets wholly artificial arrangements which do not reflect economic reality and the sole purpose of which is to avoid the tax normally payable". Similarly, following his analyses of CJEU case law in tax avoidance cases Kemmeren concluded that "the minimum threshold for refusing benefits under the EU abuse of law concept is that the dominant purpose of a particular arrangement is obtaining the tax benefit concerned." See Kemmeren (2014), p. 193. Cf. De Broe (2016), p. 238.

${ }^{243}$ Although I use the term "tax avoidance purpose", this purpose should be evaluated on objective rather than subjective grounds, as should features of wholly artificial arrangements, see supra 17.1.2. This will be selfevident in light of the objective factors defining artificial transactions noted below.

${ }^{244}$ Cf. supra 2.4. 
Polish taxpayers controlling the CFCs. This, in turn, seems to have amounted to an abuse of EU law, in this case, the abuse of freedom of establishment and the Interest and Royalties Directive.

It is noteworthy that since the artificial transaction gateway focuses exclusively on transactions between a CFC and its participants, the factors of artificiality of transactions under CJEU case law on thin capitalization and transfer pricing rules may, by analogy, be used for determining the artificiality of transactions under this gateway.

The lack of any business rationale (=commercial justification) for providing a loan or paying business expenses or granting other unusual or gratuitous advantages to associated companies (=relationship of interdependence), coupled with the lack of arm's length conditions, implies artificiality of transactions under thin capitalization and transfer pricing rules. ${ }^{245}$ If income stemming from such transactions is diverted by residents of a Member State to controlled (=associated/interdependent) companies established in low-tax EU jurisdictions for tax avoidance purposes, these transactions constitute an abuse of EU law that can be prevented under thin capitalization and transfer pricing rules. ${ }^{246}$

By analogy, in cases where CFC rules are applied, the mentioned factors of artificiality of transactions under thin capitalization and transfer pricing rules allow to expose the absence of a genuine business reason of transactions conducted between a CFC and its participants due to the lack of any substantive content produced by such transactions. ${ }^{247}$ Both types of factor actually converge as they concern payments for services that are either over or under paid, compared to their benchmark value, and/or are economically redundant for the recipients of such services except obtaining of a tax advantage.

This shows that an evaluation of transactions entailing diversions of sources of income to CFCs under CFC rules could be to some extent similar to that undertaken under thin capitalization and transfer pricing rules. In either case the overarching issue is to determine whether or not the transactions diverting income to a CFC have other purposes than to avoid taxation by persons controlling such transactions (CFC's participants). It is feasible that eliminating such transactions amounts to eliminating the purpose of existence of a CFC - it will not make sense to use a CFC for tax avoidance purposes if income diverted to the CFC from such transactions is going to be taxed under CFC rules. Thus, there is a tangible link between focusing on the conditions of transactions between a CFC and its participants, on the

\footnotetext{
${ }^{245}$ See C-524/04, paragraphs 81-82 and C-311/08, paragraphs, 66-67 and 71.

${ }^{246}$ Id.

${ }^{247}$ See AG Opinion Cadbury Schweppes, paragraph 114.
} 
one hand, and on the whole CFC structure, on the other. Likewise, there is a tangible link between ensuring a balanced allocation of taxing rights and the prevention of the use of wholly or partly artificial arrangements. In other words, the prevention of artificial transactions equals to the prevention of abusive practices by CFC's participants with respect to EU law.

The scope of the tax liability is smaller under the ,artificial transaction gateway” than under the "artificial establishment gateway" as it encompasses only a part of the CFC's income in comparison to with the entire income. Accordingly, the scope of the justification will be modified: from prevention of wholly artificial arrangements to prevention of partly artificial arrangement (=prevention of artificial transactions), or, a combination of ensuring balanced allocation of taxing rights with prevention of tax avoidance.

Last but not least, taxpayers controlling a CFC should always be able to show "without undue administrative constraint" that transactions leading to the diversion of sources of income to a CFC are commercially justified ${ }^{248}$ and therefore that the transactions are not artificial and hence that the income derived by the CFC is not "tax avoidance income".

\subsection{Evaluation and summary of the author's solution}

Given the above considerations, I believe that taxation of only "tax avoidance income" via the "artificial establishment gateway" and "artificial transaction gateway" under CFC rules ensures their compatibility with EU law and effectiveness in preventing CFC tax avoidance within the legal framework of EU. In essence, this solution aims to comply with EU's definition of the concept of "wholly artificial arrangements" 249 , which favours the internal market its purpose is to prevent: (i) artificial establishments ${ }^{250}$ and/or artificial transactions having no business purpose whatsoever ${ }^{251}$ or lacking the arm's length terms. ${ }^{252}$ In the former case, it is justified by the prevention of wholly artificial arrangements, while in the latter by the prevention of partly artificial arrangement or/and ensuring balanced allocation of taxation rights and prevention of tax avoidance. Because of the scope of its application in the latter case, i.e. beyond wholly artificial arrangement but to partly artificial arrangements (=artificial transactions), the solution seems to be effective in preventing CFC tax avoidance while maintaining its compatibility with EU law.

\footnotetext{
${ }^{248}$ See C-311/08, paragraph 71; C-201/05, paragraph 85; C-524/04, paragraph 82; and C-196/04, paragraph 70.

${ }^{249}$ Cf. Armenia and Zalasiński (2013), p. 66.

${ }^{250}$ See C-194/04, paragraph 76.

${ }^{251}$ See C-318/10, paragraphs 41-42.

${ }^{252}$ See C-524/04, paragraph 92.
} 
The solution follows from the pro-internal market interpretation of the concept of "wholly artificial arrangement". The interpretation identifies "wholly artificial CFC" with "CFC essentially engaged in non-genuine arrangements for tax avoidance purposes". ${ }^{253}$ Hence, the solution fits into the prospective transposition of ATAD to Polish domestic law (or any other EU Member State's domestic law) via Article 7(2)(b) of ATAD. However, at first glance, some issues regarding the transposition may arise insofar as my solution disregards the mechanism for of the attribution of income depending on significant people's functions and according to the arm's length principle under Article 7(2)(b) of ATAD. Still, I believe that under Article 3 of ATAD, the Polish legislature is entitled to implement my solution, since the mechanism of income attribution under my solution (attribution of tax avoidance income) seems to safeguard a higher level of protection for the domestic corporate tax base than the immensely complicated and inadequate mechanism under Article 7(2)(b) of ATAD.

Furthermore, I believe that applying CFC rules exclusively to tax „tax avoidance income" is a good means to prevent CFC tax avoidance not only for Poland and other Member States, but for all states that face this phenomenon. This is because the solution increases the effectiveness of tax avoidance prevention measures but does not distort genuine cross-border economic activities of resident taxpayers. That is to say, it is not only compatible with EU law, it also ensures an appropriate balance between the protection of the domestic tax base and the stimulation of competitiveness. This balance is likely to harmonize the ways in which CFC rules are applied by EU/EEA Member States and third countries.

The collaborative approach is also enhanced by my solution because it meets requirements of precision in preventing tax avoidance under the Polish Constitution. Since these requirements are particularly strict in Poland, ${ }^{254}$ they will likely compare favourably with similar requirements (if any) under the constitutions of other states. Moreover, it may be initially ${ }^{255}$ said that my solution has relevance in relation to tax treaties insofar as "tax

\footnotetext{
${ }^{253}$ I noticed that the Commission incorrectly distinguished between these phrases under Article $8(2)$ of the ATAD of 28 January 2016. The way I see it, CJEU case law shows that an entity involved in "non-genuine arrangements which have been put in place for the essential purpose of obtaining a tax advantage" constitutes a "wholly artificial arrangement", see C-196/04, paragraph 68; C-341/04, paragraph 35. See also C-142/99, paragraph 18; C-222/04, paragraph 112-113; and E-3/13 and E-20/13, paragraph 99. Cf. Saydé (2014), pp. 90 and 92; Smit (2014), p. 261; Lang (2010), pp. 444-445; Lang and Heidenbauer (2008), pp. 603-604; and De Broe (2008), p. 852. Hence, the distinction between "wholly artificial CFC" and "CFC essentially engaged in nongenuine arrangements for tax avoidance purposes" provided by the Commission was misleading as it incorrectly implied that a CFC engaged in non-genuine arrangements for tax avoidance purposes does not constitute a wholly artificial arrangement. Mostly likely, it was decisive for repealing this distinction from the final wording of Article 7(2)(b) of ATAD as adopted by the EU Council of 12 July 2016 (the equivalent of the Article 8(2) of the Commission's original proposal of 28 January 2016).

${ }^{254}$ See supra Chapter 14, in particular the analysis of "principles of good legislation" in 14.2.

255 For the comprehensive analysis see infra Part V.
} 
avoidance income" does not fall generally under their equivalents of Article 5 or 7 OECD MC, such that taxation of this income under CFC rules will not be precluded by the tax treaties of many Contracting States that otherwise exempt the income of foreign PEs from taxation; this applies to 71 Polish tax treaties.

It is also noteworthy that CFC rules remain effective even if they only apply for the purpose of taxing the "tax avoidance income" of a CFC irrespective of its location within or outside EU/EEA area. If it is documented and verified that the CFC derives income that is not "tax avoidance income", the risk of its involvement in tax avoidance schemes is reduced to a minimum. In other words, there will be no reason to apply CFC rules to tax income other than "tax avoidance income". This idea is correlated with and is symmetrical to the application of CFC rules by EU/EEA Member States and third countries insofar as it accurately reflects the idea presented in the paragraphs above.

One may object to the proposal by claiming that the level of economic integration between EU/EEA Member States is higher than between them and third countries. Well, CFC rules are not meant to discourage EU residents from investing in third countries. They were introduced and are applied to protect taxable residents by preventing unacceptable tax avoidance via CFCs and to create a level playing field for commerce and business. If a CFC is not involved in a tax avoidance scheme, it should not come within the scope of the CFC rules, despite being located outside the EU/EEA area. After all, what is the difference, for example, between a CFC through which a company builds and manages a hotel in Cyprus (a low-tax jurisdiction in the EU) or in the UAE (a low-tax jurisdiction outside EU/EEA)? It is hard to understand why CFCs domiciled in Cyprus can be exempt from CFC rules, while CFCs in the UAE cannot, even though both CFCs are engaged in genuine economic activities. By analogy, there is no reason to tolerate blatant CFC tax avoidance schemes that involve a CFC established in Cyprus, while combating such schemes involving CFCs in the UAE.

Still, one may argue, the proposed procedure is not required under EU law when EU residents definitely control CFCs established in third countries, because the only freedom applicable to third countries other than EEA states has no purchase in such situations (i.e. the free movement of capital does not apply in situations in which taxpayers exert a definite control over CFCs). This is true, but in my view, a better practice for EU Member States would be to apply CFC rules only to facilitate the taxation of the "tax avoidance income" of CFCs established in third countries, as was recommended in relation to CFCs established in 
EU or EEA Member States. Support for this view can be inferred from the reasoning of scholars. For instance, Pasquale Pistone pointed out that

giving protection to portfolio investments, while denying it to direct investment seems just unfair and economically counterproductive: we care about the little and ignore the big. ${ }^{256}$

In the same vein, other scholars find it "astonishing" that what creates

a framework of protection that is inversely proportional to the size of such an investment, which implies that Member States can adjust their tax laws to explicitly target direct investments in third countries without interfering with Art. 56(1) of the EC Treaty [now: Art. 63(1) of the TFUE]. Given the historically greater importance attributed by EC law to direct investments as opposed to portfolio investments, this appears to be, at least, counterintuitive. $^{257}$

To wrap up: if CFC rules were drafted such as to enable them in their application to attribute and tax exclusively the „tax avoidance income” of a foreign company, it would (i) make them compatible with EU law; (ii) secure a high level of effectiveness in preventing tax avoidance under EU law; (iii) make them applicable in exactly the same fashion by EU/EEA and nonEU/EEA Member States; and (iv) to companies established within and outside EU/EEA area. All of these advantages would enhance the collaborative approach of various states across the world to effectively prevent CFC tax avoidance.

\section{Conclusions}

The analysis undertaken in this study shows that currently the EU law still seems to facilitate tax avoidance by both EU and non-EU taxpayers rather than prevent this phenomenon. Hopefully we are very close to achieving a truly tangible shift towards an effective prevention of tax avoidance under EU law so that the internal market will be built and function properly, ensuring optimal and fair allocation of resources within the EU. Fuel to boost anti-avoidance policy under EU law seems to have triggered the international initiative of the OECD addressing BEPS, ${ }^{258}$ since the EU has been cooperating in the realization of the BEPS project via its membership in G20. The most recent effect of such a policy within the EU is reflected in the Anti-Tax Avoidance Package released by the European Commissions on 28 January 2016. ${ }^{259}$ The Commission emphasised the urgent need for action "to develop a corporate tax

\footnotetext{
256 See Pistone (2008), p. 726.

${ }^{257}$ See Cordewener, Kofler, and Schindler (2007), p. 374.

258 OECD (2013) and (2013a).

259 The package is available online at: http://ec.europa.eu/taxation_customs/taxation/company_tax/anti_tax_avoidance/index_en.htm. In addition to this document, during the last several years, the EU Council and the European Commission published documents
} 
environment in the EU that promotes a competitive and growth-friendly economy" ${ }^{260}$ Clearly, one such action is for Member States to implement and enforce effective CFC rules, especially as, in its explanatory memorandum to the Anti-Tax Avoidance Directive, the Commission stated that one of the principal aims of the CFC rules is precisely to combat "tax avoidance practices which directly affect the functioning of the internal market" and to create an "environment of fair tax competition". ${ }^{261}$ Finally, the EU Council therefore requested that the legislators of Member States take the note of Articles 7-8 of the Anti-Tax Avoidance Directive as the minimum standard for CFC rules. ${ }^{262}$

One may also say that the current developments at the level of the EU and the OECD may lead the US to shift from implicitly encouraging their MNEs to avoid taxation via EUbased CFCs through check-the-box rules, ${ }^{263}$ or explicitly praising US MNEs for their tax avoidance's practices in the EU through the voice of high positioned US politician, ${ }^{264}$ to more robust anti-avoidance legislative actions. In other words, it seems that the collaborative approach adopted by all or the vast majority of other OECD/G20/EU Member States is conducive to effective prevention of tax avoidance within as well as outside the EU. In this case, it seems rather unlikely that the US will stand apart.

I would like to recommend an approach to designing effective CFC rules that ensures their compatibility with EU law. The way I see it, taxpayers' abusive practices within the EU can now be prevented in line with the EU law by applying CFC rules to tax the "tax avoidance income" diverted to companies established within the EU under freedom of establishment or in a country, including a third country, under the principle of free movement of capital. This would most likely make it possible to combat tax avoidance schemes as analyzed in sections 3.2.2 and 3.3.2 above as well as in the Appendix below.

I am convinced that the proposal to tax the "tax avoidance income" in order to prevent tax avoidance allows both Member States and non-Member States to adopt a collaborative

regarding the problem of tax avoidance, but none of them are legally binding, see EU Council Resolution of 8 June 2010; COM(2007) 785 final; COM(2012) 351 final; and COM(2012) 722 final,; and COM(2015) 302 final, p. 6

${ }^{260}$ See $\operatorname{COM}(2016) 23 / 2$, p. 4.

${ }^{261}$ See COM(2016) 26 final, p. 3.

${ }^{262}$ See Articles 3 and 7-8 of the ATAD.

${ }^{263}$ See for example supra "Double Irish Dutch Sandwich" in section 2.3

264 Antony Ting analyzed this issue excellently, see Ting (2015), pp. 410-415. Three US senators openly defended Caterpillar in its tax avoidance's practices during the hearing. One of them even said that: "Rather than having an inquisition, we should probably bring Caterpillar here to give them an award". The video recording of the hearing is available at the US Senate Committee website: www.hsgac.senate.gov/subcommittees/investigations/hearings/caterpillars-offshore-tax-strategy. See also Arora (2014), p. 23. 
approach, which is in fact facilitated by the OECD under the BEPS Project. ${ }^{265}$ That is to say, in my view, drafting CFC rules in a way that enables them in their application to attribute and tax exclusively the "tax avoidance income" of a foreign company would make them (i) compatible with EU law; (ii) secure a high level of effectiveness in preventing tax avoidance under EU law; (iii) be applicable in exactly the same fashion by EU/EEA and non-EU/EEA member states alike; and (iv) be applicable in exactly the same fashion to companies established within and outside the EU/EEA area. All may significantly enhance the collaborative and common approach of various states across the world in preventing CFC tax avoidance.

${ }^{265}$ See OECD (2013), pp. 24-24; OECD (2013a), pp. 9 and 48; and OECD (2015a), paragraph 21. See also OECD (2014b), p. 3 . 


\section{Appendix CFC tax avoidance schemes involving Polish taxpayers}

\section{Preliminary remarks}

Appendix 1 supplements section 3.3.2 above. It includes examples of CFC tax avoidance schemes involving Polish taxpayers using companies and partnerships established in different jurisdictions: Bahrain, the Netherlands and Curaçao, Malta, Cyprus and Slovakia. In some situations, the CFC schemes involve more than one foreign jurisdictions. Apart from the scheme described in section 1.1, the examples of CFC tax avoidance schemes were drafted and analysed based on individual advance tax rulings issued by the directors of tax chambers in Poland. They are accessible at the official website of the Ministry of Finance. ${ }^{266}$ Theoretically, the scheme depicted in sections 1.1 and 1.2 can still be used for purposes of tax avoidance via CFCs by Polish taxpayers. By contrast, the schemes in sections 1.3 and 1.4 cannot currently result in CFC tax avoidance due to changes in the tax treaties, but for an understanding of the Polish schemes they are useful as snapshots at a particular time in the history of Polish tax avoidance. I have designed all the accompanying figures myself. For the sake of simplicity and clarity of presentation, apart from the partners of the Maltese LP in the scheme described in section 1.2 below, I ignore the partners of LPs (which are normally Polish LPPs holding less than 1 percent of the participation rights in LPs), and I indicate 100 percent shareholdings in foreign investment funds.

The descriptions of CFC tax avoidance schemes are offered for illustrative purposes; they are rather general and do not include every relevant legal step required for their realization. Neither do they indicate what constitutes unacceptable tax avoidance within the scope of the Polish CFC rules currently in force, not even if or when my proposals indicated in sections 4.3.3 and 5 above are implemented.

\subsection{Netherlands and Curaçao CFCs: long-term tax deferral and reduction of taxable base via payments of royalties}

The empirical studies of Markle and Robinson (2012) show that, as of 2010, the subsidiaries of Polish parent companies have been located in typical tax havens, mostly in the Netherlands

\footnotetext{
266 http://sip.mf.gov.pl/sip/.
} 
Antilles (10 percent). Although as a result of the dissolution of the Netherlands Antilles, Curaçao, among other places, became the new constituent country. The Netherlands have confirmed the application of the tax treaty in Curaçao, formerly in the Netherlands Antilles. Figure V below presents the CFC tax avoidance scheme involving Curaçao and the Dutch CFCs. The scheme allows for unlimited tax deferrals in Poland on income from royalties and allows to diminish the taxable base of a Polish taxpayer via payments of royalties to the Dutch CFC.

To set up the CFC scheme, the Polish LLC (resident in Poland for tax purposes) first has to transfer the rights to use its IP to Curaçao IP Holding Co. The transfer of the IP may be done in a tax neutral way by an in-kind contribution of the IP in exchange for the shares in Curaçao IP Holding Co. ${ }^{267}$ Since transactions between these companies are subject to transfer pricing rules, ${ }^{268}$ the price of the transferred IP must be determined pursuant to the arm's length principle. Nevertheless, determination of the arm's length price for the IP does not frustrate the tax neutrality of this transaction in Poland, ${ }^{269}$ although it does trigger the obligation to prepare transfer pricing documentation for this and for future transactions.

Curaçao IP Holding Co.'s principal object is the receipt of royalty payments from sources outside Curaçao for the benefit of non-residents (paying dividends to the Polish LLC). Hence, this company has the status of a "patent holding company", ${ }^{270}$ which is subject to profit tax at the reduced rate of 2.4 or 3 percent. ${ }^{271}$ However, with the help of a royalty ruling a reduced tax rate (a reduction of 66.6 percent) of received royalties resulting in an effective

\footnotetext{
${ }^{267}$ According to Polish tax law, no taxable income appears if shares in Curaçao IP Holding Co. are acquired via an in-kind contribution of the IP to the amount of the nominal value of shares in Curaçao IP Holding Co. and the part of the increase of the contributed IP's value over the acquired nominal value of the shares of the Curaçao IP Holding Co. are allocated to Curaçao IP Holding Co.'s supplementary (reserve) capital. In this case, taxable costs will likely equal the revenue and thus no taxable income appears (nil tax base). See Article 12(1) point 7 in conjunction with Article 15(1j) point 1 CITA. In the worst tax scenario, the nominal value of the acquired shares of Curaçao IP Holding Co. will be taxed, but this value may be minimal. See, however, the outcome of changes in Polish tax law supra footnote 125.

${ }^{268}$ Regardless of whether these companies are associated in the meaning of transfer pricing rules, Curaçao is listed as a tax-harmful jurisdiction and therefore all transactions with an entity located in that country fall within the scope of transfer pricing rules. See Article 11(4a) CITA in conjunction with $\S 1$ point 4 of the Ministry of Finance of 23 April 2015, item 599.

${ }^{269}$ Besides, determining the arm's length price of the IP is usually very difficult as the intangible is only partially developed at the time of transfer and risk is associated with future earnings. As a result, multinational companies have considerable leeway in determining the price under the cost-sharing agreement, see Fuest et al. (2013), p. 311.

270 The term "patent holding company" embraces not only companies whose activity consists in holding patents per se but also holding copyrights, designs, secret techniques or processes and trademarks; film copyrights, rights over industrial, commercial and scientific installations; and rights to the exploitation of a mine or quarry or to extract their natural resources, see Truijens (2014), p. 19.

${ }^{271} \mathrm{Id}$.
} 
tax rate of 1 percent. ${ }^{272}$ Thus, the Curaçao IP Holding Co. may earn high revenues from royalties paid by its customers in different countries. Since no physical presence is created in the countries of final consumption of the IP, as a rule, the profits from royalties cannot be taxed there. ${ }^{273}$

However, the royalties are not paid directly to Curaçao IP Holding Co., but channelled through a Dutch Conduit Co., which sublicenses the IP to final customers. Interposing a company in the Netherlands allows for treaty and EU directive shopping, since that country has tax treaties with around 100 jurisdictions ${ }^{274}$ and is a member state of the EU. ${ }^{275}$ Furthermore, the Netherlands do not impose withholding tax on any royalty payments, irrespective of the residence state of the receiving company. ${ }^{276}$ There is no withholding tax on royalties in Curaçao, either. ${ }^{277}$ Consequently, by channelling royalty payments from the users of IP (within the EU and most of the Netherlands' tax treaty partners) via the Dutch Conduit Company to Curaçao, withholding taxes can be completely avoided. This is of great importance for this CFC scheme because there is insufficient tax in Curaçao (1 or max. 3 percent) to be credited against withholding taxes on royalties paid by the final customers of the IP. The tax base of the Dutch Conduit Co. is close to zero because it pays high taxdeductible royalties for the use and sublicensing of the IP owned by the Curaçao Holding Co.

Similarly, IP may be sublicensed by the Dutch Conduit Co. to the Polish LLC and that company, in turn, will use IP for its operational activities. The Polish LLC will pay high taxdeductible royalties to the Dutch Conduit Co. Due to the Polish tax law implementing the

\footnotetext{
${ }^{272}$ Information retrieved from the website of Curaçao fiduciary service providers, see Curaçao Royalty Companies, available online at: http://www.premier-mp.com/royalty-company.html.

${ }^{273}$ Cf. Fuest et al. (2013), p. 311. Of course it may happen that royalties paid from particular countries will be taxed there due to their domestic tax laws. The prominent example of such a country is India, where royalties and fees paid to non-residents for technical services are subject to withholding tax in India even under a given tax treaty (India follows the UN Model in that regard), see Gupta (2015),p. 32.

274 The full list of tax treaties signed by the Netherland is available online at: http://www.belastingdienst.nl/wps/wcm/connect/bldcontenten/belastingdienst/individuals/tax_arrangements/tax_ treaties/overview_of_treaty_countries/.

${ }^{275}$ One may wonder whether the Dutch Conduit Co. is a beneficial owner of the royalties received from users of IP or just an intermediary. This must be evaluated on a case-by-case basis, since the status of beneficial owner is differently evaluated by tax authorities in various countries under tax treaties and the EU Directive. For example, in Poland, tax authorities use beneficial ownership clauses only to challenge the status of a beneficial owner in relation to agents and fiduciaries in cash-pooling agreements. The status of conduit companies as beneficial owners is not challenged. See, for instance, advance tax ruling issued by DTCh in Poznań of 3 March 2011; 21 December 2011; and DTCh in Katowice of 10 November 2011.

${ }^{276}$ See Boekhorst (2015), p. 58.

${ }^{277}$ See Truijens (2014), p 6.
} 
provisions of the I \& R Directive, there will be no withholding taxation on royalties paid by the Polish LLC to the Dutch Conduit Co. ${ }^{278}$

Income from royalties accumulated by the Curaçao IP Holding Co. is taxed at a very low level, i.e. 1 percent effective tax rate or max. 3 percent. ${ }^{279}$ The outcome is that this income will not be taxed at the level of the Polish controlling shareholder even when it is transferred to Poland in the form of dividends. ${ }^{280}$ The income received by the Polish LLC will not be taxed at the level of its Polish shareholder only when it is transferred to him or her in the form of dividends - unlimited tax deferral.

Figure V: CFC scheme involving Curaçao and the Dutch CFCs: long-term tax deferrals and reduction of taxable base via payments of royalties

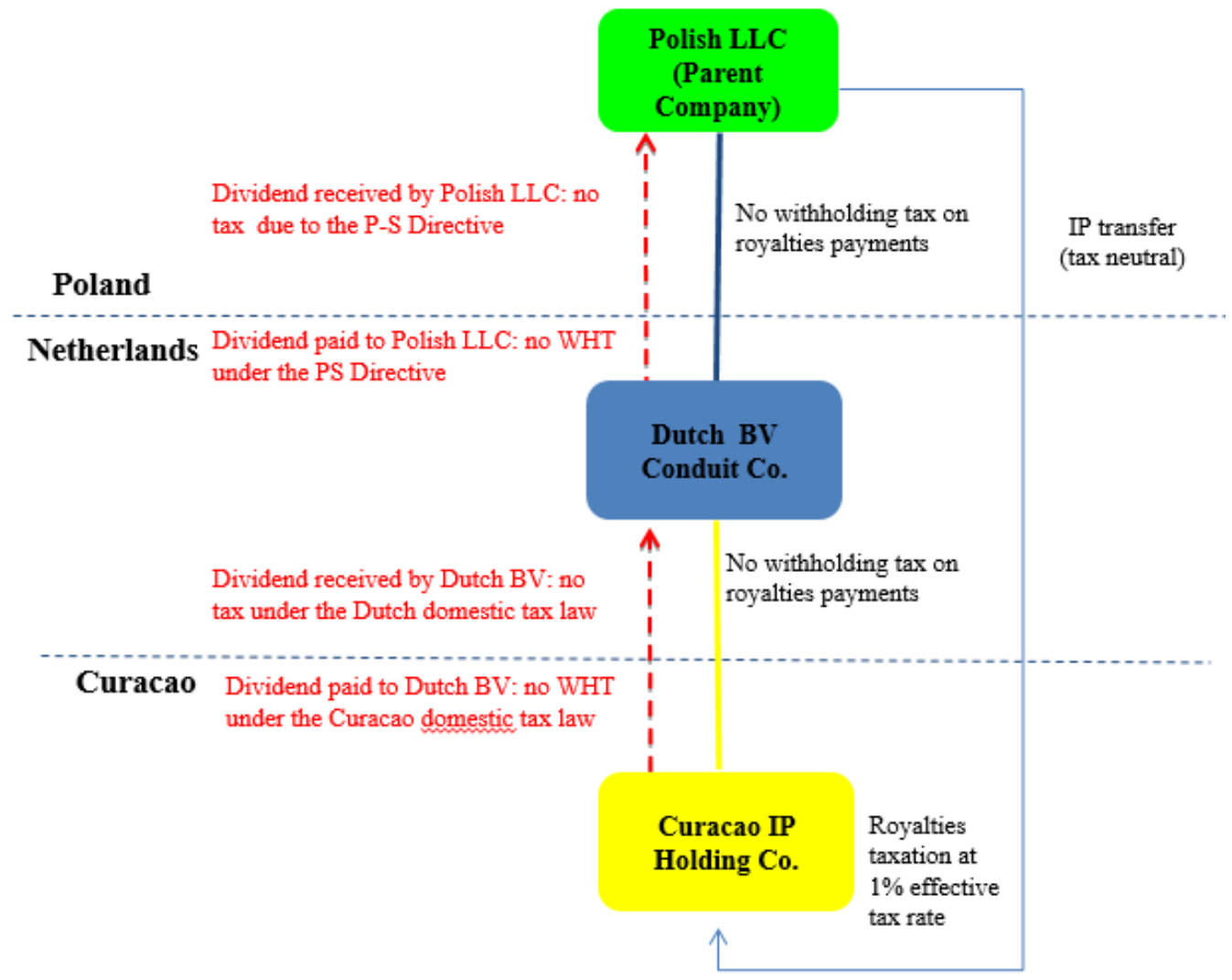

\footnotetext{
${ }^{278}$ Pursuant to the Article 21(3)-(4) CITA, royalty payments to companies resident in an EU or EEA country other than Poland are exempted from withholding taxation in Poland if (i) the recipient directly participates for an uninterrupted period of 2 years (commitment being sufficient) in the Polish entity with at least 25 percent shareholding or if another company has directly at least a 25 percent shareholding in the payer's and recipient's capital; (ii) there is a legal basis for exchange of information relating to tax matters; (iii) and the recipient provides the remitter with a declaration stating that it is not exempt from tax on its worldwide income in the country of residence irrespectively of the source of such income.

${ }^{279}$ This tax may be decreased to zero by attributing to Curaçao IP Holding Co. tax deductible costs in an amount equal to 1 percent or 3 percent of its revenue.

${ }^{280}$ Dividends paid by Curaçao IP Holding Co. to the Dutch Conduit Co. are neither tax in Curaçao (no withholding tax on dividends in general) nor in the Netherlands (the domestic participation exemption). See Truijens (2014), p. 19 and Boekhorst (2015), p. 78. Then dividends paid by the Dutch Conduit Co. to the Polish CFC are exempt from taxation in both the Netherlands and Poland in accordance with the provisions of the Parent-Subsidiary Directive (2011/96).
} 


\subsection{Maltese CFCs: reduction of effective taxation to 5 percent}

This CFC scheme is structured in almost the same way as the scheme described in subsection 3.3.2.1 above, except that instead of the PICIS, an ordinary LLC was established in Malta and there is no LP located in Poland in which the Maltese LLC holds any shares. This structure does not lead to tax avoidance for an income generated on the current basis in Poland, but to the avoidance of an income derived by the Maltese LLC by providing various services to its customers. Thus, if rendering such services has a business purpose beyond obtaining tax benefits, this scheme should not be seen as a CFC tax avoidance scheme, but as a genuine economic structure. For the purpose of the current discussion, I assume that these services have no business purpose apart from gaining tax benefits.

In this CFC scheme, the Polish taxpayer became a general partner in an LP in Malta with almost 100 percent participation in its rights and duties, while another Polish taxpayer became a limited partner in that company. ${ }^{281}$ The LP, in turn, owns 100 percent of the LLC and receives income from the LLC in the form of dividends. The Polish taxpayer, being a general partner, receives almost all the income from the LP on an ongoing basis, since it constitutes for him a foreign PE under Poland's treaty with Malta. From the Maltese tax law point of view (and from the Polish as well), the LP is tax transparent, so the look-through approach applies to dividends paid by the LLC to LP - the recipient of the dividends is considered as a foreign tax resident (the Polish taxpayers). There is no withholding tax on dividends paid to non-resident individuals pursuant to the Maltese tax law. ${ }^{282}$ Dividends received by the Polish taxpayers via the LP qualify as profits of a foreign PE, i.e. business income taxable under Article 7(1) in conjunction with Article 10(4) of Poland - Malta tax treaty. The exemption method applies to such income in Poland pursuant to Article 23 (1) letter $b$ of the treaty.

The LLC's income is taxed at a 35 percent tax rate in Malta, but a full imputation tax system is applicable there so that tax paid by the Maltese company is imputed to the shareholders in the event of a dividend distribution for which they may subsequently claim tax refund with respect to taxes paid by taxable companies, e.g. by an LLC. Both resident and non-resident shareholders, be they individuals or companies, are entitled to the tax refund. In

\footnotetext{
${ }^{281}$ The reason why in the Maltese LP almost 100 percent of participation has a general partner, but not a limited partner like in the previous schemes, is that under the Maltese company law a general partner of the LP must be either an individual or a body corporate which has its obligations guaranteed by the unlimited and joint and several liabilities of one or more of its members. So it is not possible to reduce the civil liability of the general partner of the Maltese LP by putting a LLC on this position. See the Companies Act of 1 January 1996, Chapter 386, Section 51 (7), S.L.386.01.

${ }^{282}$ See Zarb and Portelli, (2015), p. 30.
} 
this CFC scheme, the Polish taxpayers will be entitled a tax refund, but not the LP, since the company is tax transparent and the Polish taxpayers therefore considered to be shareholders of the LLC. They will be entitled to a refund equivalent to six-sevenths of the tax paid by the Maltese LLC. ${ }^{283}$ The tax refund received by the Polish taxpayers from the Maltese tax authorities is taxable exclusively in Poland under Article 21(1) of Poland - Malta tax treaty ("other income"). This refund does not qualify as taxable income in Poland. In consequence, the effective tax rate of the income generated by the LLC in Malta and received by the Polish taxpayers will amount to 5 percent. The tax effects of this CFC scheme are confirmed in advance tax rulings. ${ }^{284}$

Figure VI: CFC scheme with Maltese CFCs: reducing effective tax rate to 5 percent

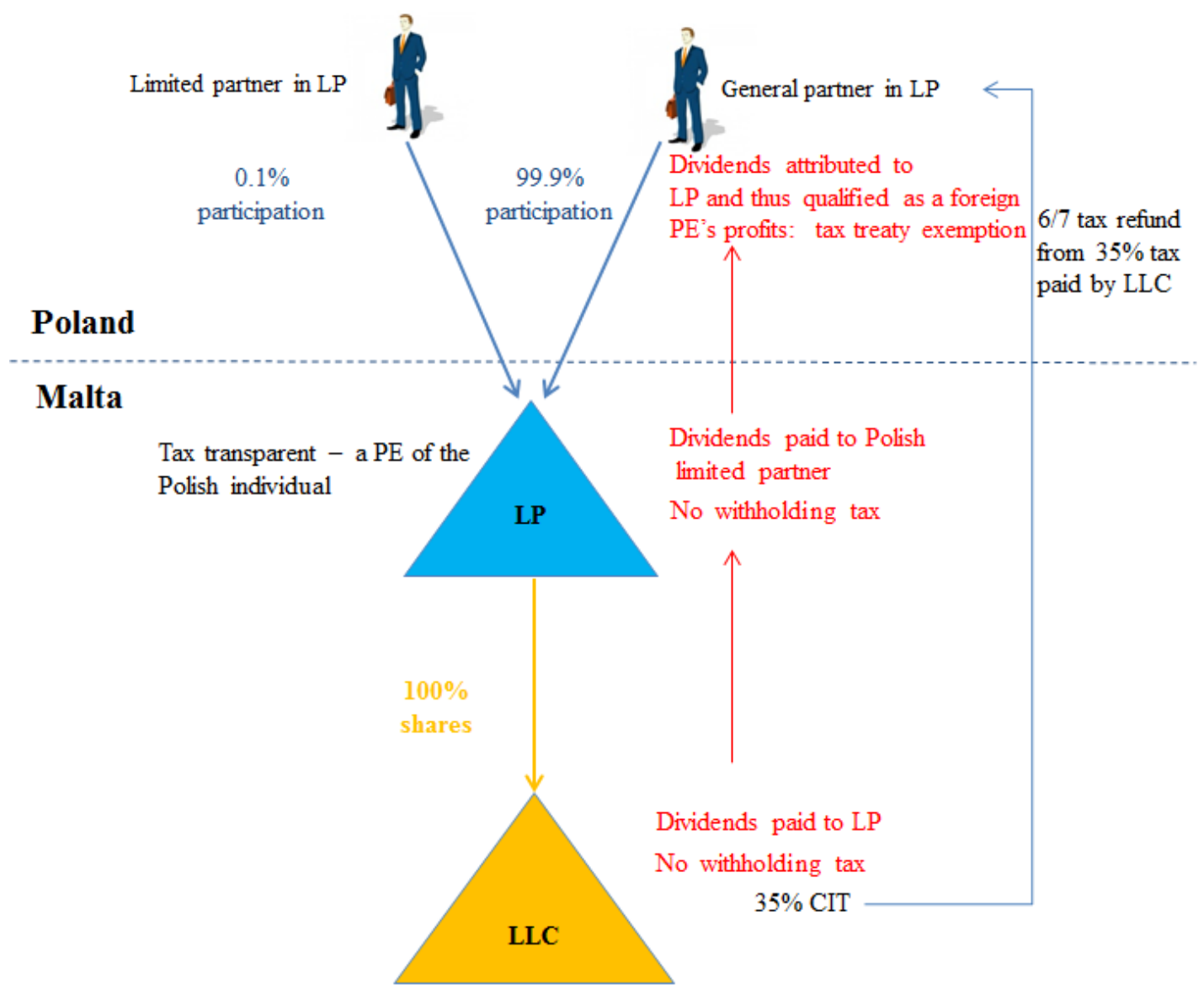

${ }^{283}$ See Torregiani (2015), pp. 53-54.

${ }^{284}$ See advance tax rulings issued by DTCh in Poznań of 29 October 2013 and of 18 July 2013. 


\subsection{Slovak and Cypriot CFCs: a triangular structure resulting in triple non-taxation}

The scheme presented in figure VIII is an example of the repatriation of non-taxed profits from abroad to Poland via a Cypriot and a Slovak CFC without any income taxation (it is a modification of the scheme described in subsection 3.4.1 above).

The first step in the procedure of setting up this CFC scheme is analogous to that described in subsection 3.3.2.1. Subsequently, a new LP in Slovakia (Slovak LP) is established. Next, the Polish taxpayer transfers shares of the Cypriot PICIS to the Slovak LP. The shares are transferred as an in-kind contribution in exchange for a participation percentage in the Slovak LP, which is a tax neutral transaction. ${ }^{285}$ As a consequence of the inkind contribution, the Slovak LP owns 100 percent of the shares in the PICIS and the Polish taxpayer owns 100 percent participation rights in the Slovak LP. ${ }^{286}$ Thus, the Slovak LP becomes a beneficiary of the dividends paid by the Cypriot PICIS (which derives income from the Polish LP) and the Polish taxpayer will be entitled to dividends paid by the Slovak LP. Dividend payments from the Cypriot PICIS to the Slovak LP are neither taxed in Cyprus nor in Slovakia under their ordinary domestic tax laws. ${ }^{287}$ There is no further withholding taxation on dividends paid by the Slovak LP to the Polish taxpayer. ${ }^{288}$ In light of the Poland Slovakia tax treaty, the dividends received by the Polish taxpayer (acting as a general partner of the Slovak LP) from the Slovak LP are qualified as profits from its PE located in Slovakia and, consequently, are exempted from taxation in Poland under Article 10(4) and Article 7 in conjunction with Article 24(1) of Poland - Slovakia tax treaty in the form of exemption with progression. ${ }^{289}$

\footnotetext{
${ }^{285}$ An income derived from the in-kind contribution of the PICIS' shares to the Slovak LP in exchange of its shares is taxable exclusively in Poland - Article 13(4) of Poland - Slovakia tax treaty. Subsequently, according to Article 21(1) point 50b PITA, such income is exempted from PIT taxation in Poland.

${ }^{286}$ Clearly, there has to be at least two partners in the Slovak LP. In fact, the PICIS is a limited partner of the Slovak LP with almost total participation rights in this entity (99.99 percent) and the remaining participation percentage ( 0.01 percent) belongs to a Polish or Slovak LLC. In consequence, not only tax, but also the civil liabilities (liability for obligations) of the Slovak LP are reduced to zero. The Polish or Slovak LLC acting as a general partner of the Slovak LP was omitted in Figure VII to simplify the CFC scheme. See supra 1.1.

${ }_{287}$ Dividends paid by a non-resident company from profits generated as of 1 January 2004 are not subject to any Slovak tax in the hands of resident shareholders. It is also worth noting that limited partnerships in Slovakia are partially subject to CIT - but only on the income attributable to their limited partner. The other part of the income is taxed in the hands of their general partners, see Antala et al. (2015), p. 15.

No withholding tax is levied on dividends paid by a Cypriot company out of its profits to non-residents, both individuals and companies, see Taliotis (2015), p. 25.

${ }^{288}$ Dividends paid out of profits derived by a Slovak company to resident and non-resident individuals are generally exempted from taxation, see Dumitrescu (2015), p. 16

${ }^{289}$ See Article 27(8) PITA.
} 
This scheme is somewhat similar to treaty shopping, since if the dividend payments were not made through the Slovak CFC to its controlling Polish shareholder, there would be dividend taxation in Poland. The Slovak CFC is a conduit company (an intermediary between the Cypriot PICIS which is a based company and its controlling shareholder in Poland) and the Slovakia is a conduit state (a state between the source-state of dividends and the residence state of a beneficiary of these dividends). This, however, is not a typical tax treaty shopping scheme because it does not stem from favourable tax treaty provisions between Slovakia and Cyprus any more than under the tax treaty between Poland and Cyprus, but from the combination of preferential tax treatment of dividends under domestic Slovak and Cypriot tax laws and the hybrid qualification of dividends paid from Slovakia to Poland, i.e. in Slovakia they are qualified as exempted from taxation dividend, while in Poland as tax-exempted business income of a Polish taxpayer received via a PE located in Slovakia. Consequently, the CFC's controlling participant claims an otherwise unavailable tax exemption in Poland.

The tax consequences of the CFC scheme described above were approved in many advance tax rulings. ${ }^{290}$

It should be noted that this CFC tax avoidance scheme has been ineffective since 1 January 2015, because the Ministry of Finance re-negotiated the Poland - Slovak tax treaty and changed the exemption method for the credit method in relation to business income of an enterprise derived via a PE in Slovakia.

\footnotetext{
${ }^{290}$ See for instance: advance tax ruling issued by DTCh in Katowice of 27 April 2011; DTCh in Poznań of 2 December 2011; and DTCh in Warsaw of 17 July2012.
} 
Figure VII: CFC scheme involving Cypriot and Slovak CFC: triple non-taxation of income sourced in Poland

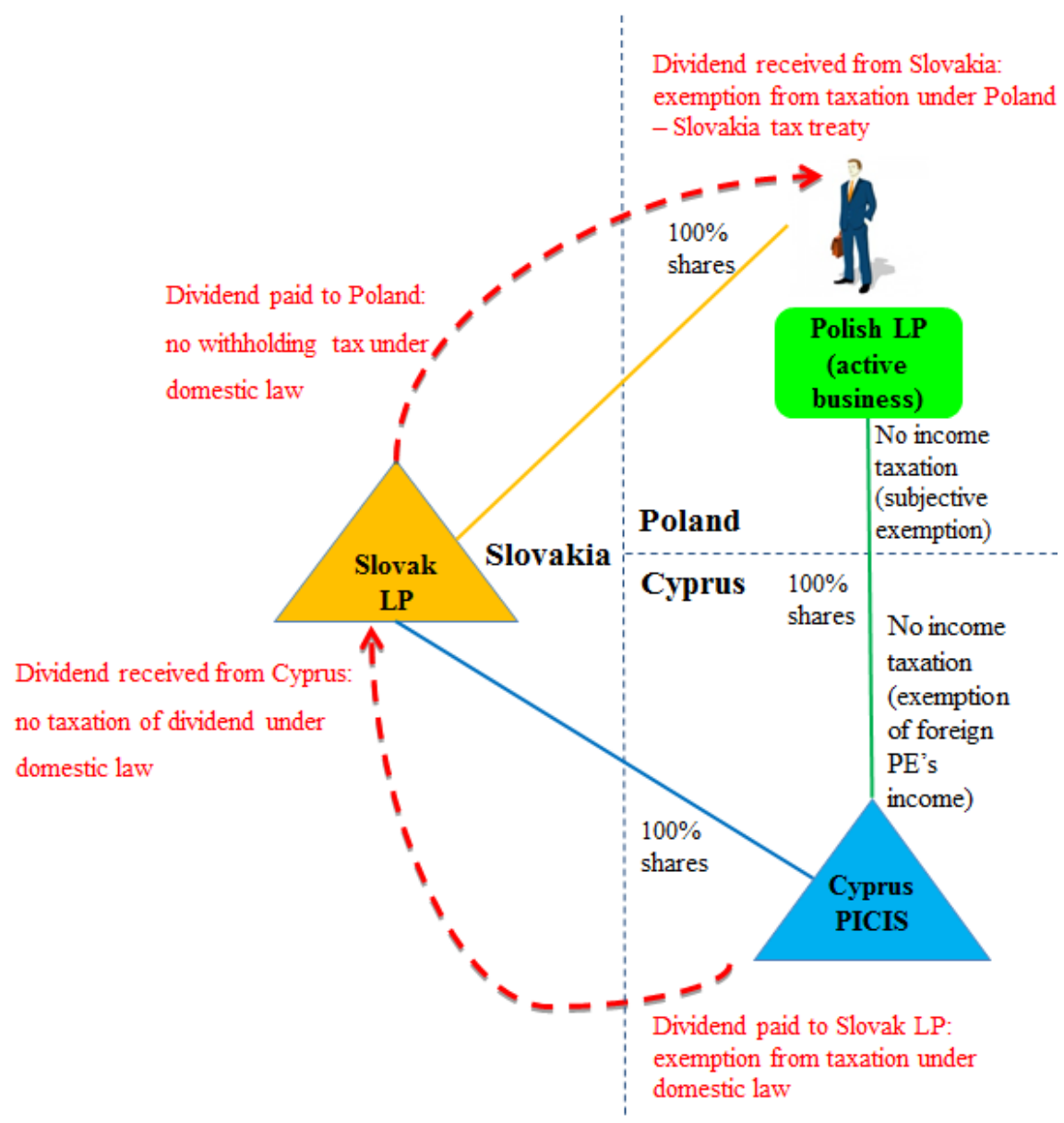

\subsection{Cypriot CFC: double non-taxation of director fees and unjustified tax sparing clause}

The scheme presented in figure IX below is an example of the repatriation of non-taxed profits from abroad to Poland via a Cypriot CFC without any income taxation. The procedure of setting up this CFC scheme is identical to that presented in subsection 3.3.2.1, that is to say, it is an extension of the previous scheme.

Here, the application of the tax sparing clause results in reduced taxation on dividends paid by a Cypriot CFC to its Polish shareholders from 19 to 9 percent. This possibility existed because of the difference between the Polish and English versions of the article 24(1)(b) of Poland - Cyprus tax treaty that included a tax credit method for eliminating double taxation. Until the end of 2012, these versions had the same content with one exception. The Polish version read as follows

(...)where a resident of Poland derives income which, in accordance with Articles 10, 11 and 12 of this tax treaty may be taxed in Cyprus, Poland shall allow as a deduction from 
the tax on the income of that resident an amount equal to the tax paid (podatek zaplacony) in Cyprus. [Emphasis added]

Whereas in the English version the phrase "tax payable" (podatek podlegajacy zapłacie) replaced the phrase "tax paid". According to Article 30 in fine of the Poland - Cypriot tax treaty, in the event of any discrepancy in the interpretation of the tax treaty, the English version prevails.

Furthermore, pursuant to Article 24(3) of Poland - Cypriot tax treaty, the phrase "tax payable" includes taxes that would have been payable but, under the domestic tax law of a contracting state, are exempted, as income from dividends paid by a Cypriot company to its foreign shareholders is exempted from tax in Cyprus. In consequence, the Polish taxpayer who receives the dividend paid by a Cypriot company is entitled to deduct an amount equal to 10 percent $^{291}$ of the gross dividend from the tax due in Poland, regardless of whether the tax on those dividends was actually paid in Cyprus.

Interestingly the tax sparing clause was applicable under the Poland - Cypriot tax treaty only because of discrepancies between Polish and English versions of the treaty and the relief of taxation on dividends in Cyprus was not connected with any contribution of Polish taxpayers to the economy of that state, so that applying this clause resulted in losses for the Polish Treasury. Thus one may say that this clause was harmful to the Polish tax system from the very beginning.

Moreover, the Polish taxpayer is a member of PICIS's board of directors and therefore a recipient of director fees. Pursuant to Article 16 of the Poland - Cypriot tax treaty, director fees may be taxed both in the resident (Poland) and the source state (Cyprus). Under Article 24(1)(a) of this tax treaty, such income is exempted from taxation in Poland. In Cyprus, in turn, director fees are exempted from taxation if they are paid to non-residents. ${ }^{292}$ As a result, this income is repatriated to Poland without taxation in either of the countries.

The tax consequences of this CFC scheme, like the CFC schemes allowing for double non-taxation of director fees, were approved in favour of taxpayers by the Ministry of Finance in many advance tax rulings. ${ }^{293}$

After several years of tax avoidance by Polish taxpayers based on that tax sparing clause and double non-taxation of directors' fees, the Ministry of Finance finally decided to

\footnotetext{
${ }^{291}$ Until 31 December 2012 the CIT tax rate in Cyprus was at the level of 10 percent. From 1 January 2013 the CIT rate was increased to 12.5 percent, see Taliotis (2015), p. 9.

${ }^{292}$ See Taliotis (2015), p. 45.

${ }^{293}$ See for instance: advance tax ruling issued by DTCh in Warsaw of 27 November 2009 and 25 March; DTCh in Poznań of 31 October, 2012.
} 
renegotiate the Poland - Cyprus tax treaty with effect from 1 January 2013 in order to repeal the clause and amend Article 16 so that tax director's fees are subject to tax only in the resident state of the director. Hence, since 1 January 2013, Polish taxpayers have not been able to avoid taxation in this way.

Figure VIII: CFC scheme involving Cypriot CFC: the application of the unjustified tax sparing clause

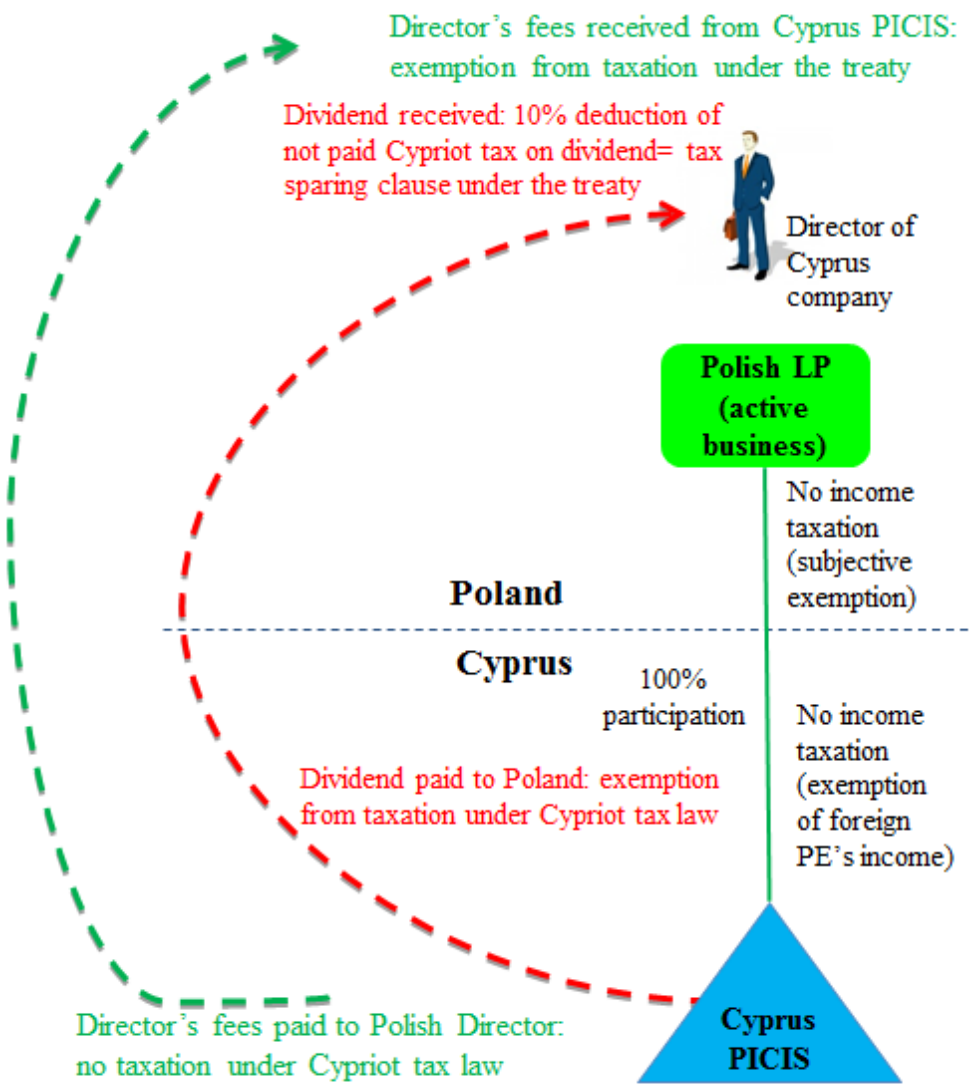

\section{Conclusions}

The presentation of the Polish CFC tax avoidance schemes in this Appendix confirm several interesting findings and conclusions made in section 3.4 above. In brief, most CFC schemes were designed and applied via the use of CFCs established in jurisdictions indicated in Reports 2011 and 2013 as the most attractive destinations for Polish investors' FDIs, including Cyprus, the Netherland, and Malta. It confirms the previous assumption that the majority of Polish FDIs over the last ten years have been solely or mainly driven by the prospect of tax savings rather than economic motives. Moreover, in most of the schemes, Polish taxpayers, most often individuals, have deliberately avoided taxation on income generated by business activities run by them in Poland through tax transparent partnerships. 
This allows Polish individuals controlling CFCs to entirely avoid taxation on income and shows that CFC tax avoidance in Poland deviates significantly from mainstream schemes internationally in which companies normally benefit from tax avoidance through long-term tax deferrals. 


\section{References}

\section{Bibliography}

Anderson, J. \& Jupp, A. (2013), United Kingdom - National Report: The taxation of foreign passive income for groups of companies, Cahiers de droit fiscal international, Vol. 98a, IFA Congress in Copenhagen.

Anker-Sørensen, L., (2016), Financial Engineering as an Alternative, Invisible Veil for the

Corporate Group, University of Oslo Faculty of Law Legal Studies Research Paper Series No. 2016-01, http://papers.ssrn.com/sol3/papers.cfm?abstract_id=2729112.

Antale et. al. (2015), Slovak Republic-Corporate Taxation, Amsterdam: IBFD Tax Research Platform (Last Reviewed: 1 June 2015), pp. 7 and 16.

Arnold, B. J. (1986), The Taxation of Controlled Foreign Companies: An International Comparison, Canadian Tax Paper no. 78, Toronto: Canadian Tax Foundation.

Arnold, B. J. \& Dibout, P. (2001), General Report Limits on the Use of Low-tax Regimes by Multinational Businesses: current measures and emerging trends, Cahiers de droit fiscal international, Vol. 86b, IFA Congress in San Francisco.

Arora, J. (2014), Caterpillar, PwC under fire at Senate hearing, Tax Notes International 2014, 7 April.

Avi-Yonah, R. S. (2007), International Tax as International Law: An Analysis of the International Tax Regime, Cambridge: Cambridge University Press.

Avi-Yonah, R. S. (2014), Back From the Dead: Reviving Transfer Pricing Enforcement, Tax Notes International 2014, 6 January.

Avella, F. (2013), Italy - National Report: The taxation of foreign passive income for groups of companies, Cahiers de droit fiscal international, Vol. 98a, IFA Congress in Copenhagen.

Baker, Ph., (ed) (2014), Double Taxation Conventions $3^{\text {rd }}$ edition, London: Sweet \& Maxwell, (loose-leaf format), November. 
Bardini, Ch. \& Lambio, M. (2015), Luxembourg -Corporate Taxation, Amsterdam: IBFD Tax Research Platform.

Barnard, C. \& Deakin, S. (2002), Negative and Positive Harmonization of Labor Law in the European Union, Columbia Journal of European Law 2002, Vol. 8.

Báez, A. \& Zornoza, J. (2013), Spain - Branch Report: The taxation of foreign passive income for groups of companies, Cahiers de droit fiscal international, Vol. 98a, IFA Congress in Copenhagen.

Bartosiewicz, A. \& Kubacki. R. (2015), Komentarz do art.27(g) ustawy o podatku dochodowym od osób fizycznych, in PIT. Komentarz, $5^{\text {th }}$ edition, LEX 2015, electronic version via Lex Omega Intranet, No. 10145.

Bellingwout, J. W. (2015), Blueprint for a New Common Corporate Tax Base, European Taxation 2015, No. 1.

Biondi, Y (2011), The Pure Logic of Accounting: A Critique of the Fair Value Revolution, 2011, No. 1, Vol, http://www.degruyter.com/view/j/ael.2011.1.1/ael.2011.1.1.1018/ael.2011.1.1.1018 .$x m l$.

Blanchard, K. S. (2015), BEPS Action 3: How Not to Engage with CFC Rules, Premier International Tax Library 2015, 1 July 2015, access online: http://www.bna.com/beps-action-not-n17179928956/.

Boekhorst, te P. (2015), Netherlands-Corporate Taxation, Amsterdam: IBFD Tax Research Platform, (Last Reviewed: 23 September 2015).

Brewer, T. L. \& Young, S. (1998), Multilateral Investment System and Multinational Enterprises, Oxford: Oxford University Press.

Brzeziński, B. \& Kalinowski, M. (1993), Glosa do wyroku NSA z dnia 7 listopada 1991 r. SA/Po 1198/91, OSP 1993, No. 10.

Cordevener, A. (2006), The Prohibitions of Discrimination and Restriction within the Framework of the Fully Intergrated Internal Market, in Vanistendael F. (ed.), EU Freedoms and Taxation, EATLP International Tax Series, Vol. 2, Amdsterdam: IBFD. 
Dahlberg, M. \& Wiman, B. (2013), General Report: The taxation of foreign passive income for groups of companies, Cahiers de droit fiscal international, Vol. 98a, IFA Congress in Copenhagen.

De Broe, L. (2008), International Tax Planning and Prevention of Abuse: A Study under Domestic Tax Law, Tax Treaties and EC Law in Relation to Conduit and Base Companies, Doctoral Series IBFD - Academic Council, Vol. 14, Amsterdam: IBFD.

De Broe, L. (2016), "Tax treaty and the EU Law aspects of the LOB and PPT provision proposed by BEPS Action 6", in Danon, R. (ed.), Base Erosion and Profit Shifting (BEPS): Impact for European and international tax policy, Zurich: Schulthess, 2016.

De Graaf, A., De Haan, P., \& De Wilde, M. (2014), Fundamental Change in Countries' Corporate Tax Framework Needed to Properly Address BEPS, Intertax 2014, Vol. 42, No. 5.

De Hosson, F. C. (2006), On the controversial role of the European Court in corporate tax cases, Intertax 2006 ,Vol. 34, No. 6/7.

Dumitrescu, L. (2015), Slovak Republic - Individual Taxation, Amsterdam: IBFD Tax Research Platform, (Last Reviewed 1 June 2015).

Eidenmüller, H. (2011), Abuse of Law in the Context of Euroepan Insolvency Law, in De la Feria, R. and Vogenauer, S. (eds.), Prohibition of Abuse of Law: A New General Principle of EU?, Oxford: Hart Publishing.

Estageri, P. J. (2015), Luxembourg - Individual Taxation, Amsterdam: IBFD Tax Research Platform, (Last reviewed: 1 March 2015).

Evans, Ch. (2009), Containing Tax Avoidance: Anti-Avoidance Strategies, in Head, G. J., Krever, R. (eds.), Tax Reform in the 21st Century. A Volume in Memory of Richard Musgrave, Series on International Taxation, Alphen aan den Rijn: Kluwer Law International.

Fennelly, N. (1997), Legal Interpretation at the European Court of Justice, Fordham International Law Journal 1997, No. 20. 
Fuest, C., Spengel, C., Finke, K., Heckemeyer, J. \& Nusser, H. (2013), Profit Shifting and “Aggressive” Tax Planning by Multinational Firms: Issues and Options for Reform, World Tax Journal 2013, No. 10.

Furuseth, E., (2016), The Relationships between Domestic Anti-Avoidance Rules and Tax Treaties, Oslo: PhD thesis series, 2016.

Gerson, A. (2013), Sweden - Branch Report: The taxation of foreign passive income for groups of companies, Cahiers de droit fiscal international, Vol. 98a, IFA Congress in Copenhagen.

Gibbons, W. J. (1956), Tax Effects of Basing International Business Abroad, Harvard Law Review 1956, vol. 69.

Graetz, M. J., \& O'Hear, M. (1997), The 'Original Intent' of U.S. International Taxation, Duke Law Journal 1997, Vol. 47.

Gueydi, S. (2015), United Arab Emirates - Corporate Taxation, Country Surveys, IBFD Tax Research Platform (Last Reviewed: 1 March 2015).

Gupta, P. (2015), India-Corporate Taxation, Amsterdam: IBFD, Asia-Pacific Tax Research Platform, (Last Reviewed: 1 January 2015).

Helminen, M. (1999), The Dividend Concept in International Tax Law: Dividend Payments Between Corporate Entities, Series on International Taxation, Kluwer Law International, London.

Helminen, M. (2015), EU Tax Law - Direct Taxation, Amsterdam: IBFD, Online Books via IBFD Tax Research platform, Last Reviewed: 13 July 2015.

Hemels, S. J. C. (2009), References to the Mutual Assistance Directive in the Case Law of the CJEU: A Systematic Approach, Europan Taxation 2009, No. 12.

Herzig, N., Teschke, M., \& Joisten, Ch. (2010), Between Extremes: Merging the Advantages of Separate Accounting and Unitary Taxation, Intertax 2010, Vol. 38, No. 6/7.

Jacquot, N. (2013), France - National Report: The taxation of foreign passive income for groups of companies, Cahiers de Droit Fiscal International, Vol. 98a, IFA Congress in Copenhagen. 
Jaworek, M. (2008), Stymulanty $i$ destymulanty podejmowania inwestycji bezpośrednich za granica przez polskie przedsiębiorstwa, in Karaszewski, W. (ed.), Bezpośrednie inwestycje zagraniczne. Polska na tle świata, Toruń: TNOIK.

Jiménez, A. M. (2012), “Towards a Homogeneous Theory of Abuse in EU (Direct) Tax Law”, Bulletin for International Taxation 2012, No. 4-5.

Karaszewki, W. (2009), Polish Foreign Direct Investment, in Karaszewski, W. (ed.), Foreign Direct Investments of Polish Companies: its scale structure, determinants, influences on the competetivness, Toruń: TNOiK.

Karimeri, R. (2011), A Critical Review of the Definition of Tax Avoidance in the Case Law of the European Court of Justice, Intertax 2011, Vol. 39, No. 6-7.

Kemmeren, E. C. C. M. (2008), The Internal Market Approach Should Prevail over the Single Country Approach, in Hinnekens, L. and Hinnekens, P. (eds), A Vision of Taxes Within and Outside European Borders. Festschrift in Honour of Prof. Dr Frans Vanistendael, Alphen aan den Rijn: Kluwer Law International.

Kemmeren, E. C. C. M. (2014), "Where is EU Law in the OECD BEPS Discussion?”, EC Tax Review 2014, No. 4.

Kleinbard, E. D. (2013), Through a Latte Darkly: Starbucks's Stateless Income Planning, Tax Notes International 2013, June 24.

Kobetsky, M. (2008), The Case for Unitary Taxation of International Enterprises, Bulletin for International Taxation 2008, No. 5.

Koerver Schmidt, P. (2013), Denmark - Branch Report: The taxation of foreign passive income for groups of companies, Cahiers de droit fiscal international, Vol. 98a, IFA Congress in Copenhagen.

Kofler, G. and Tumpel, M. (2009), “““Abuse” in Direct and Indirect Community Tax Law: A Convergence of Standards", in Lang, P. Melz, E. Kristofferson (eds.), Value Added Tax and Direct Taxation: Similarities and Differences, Amsterdam: IBFD, 2009.

Koukakis, N. (2015), EU moves to close the tax loophole for multinationals, Europe News at CNBC, available online at: http://www.cnbc.com/2015/10/06/eu-moves-to-closethe-tax-loophole-for-multinationals.html. 
KPMG (2015), Cyprus Tax Guide 2015, available online at: http://www.kpmg.com/CY/en/IssuesAndInsights/ArticlesAndPublications/Docume nts/2015-documents/Tax-Guide-2015.pdf.

Kuźniacki, B. (2013b), Dubious Taxable Status of Polish Tax Capital Groups, Tax Notes International 2013, 14 October 2013.

Kuźniacki, B. (2014), Jak LPP unika podatków, Forbes 2014, 23 January 2014, available online at: $\quad$ http://www.forbes.pl/jak-lpp-unika-podatkow$\underline{\text { schemat,artykuly, 169955,1,1.html. }}$

Kuźniacki, B. (2015), “CFC Rules, BEPS Action 3 (Draft), and EU Law”, WU International $\begin{array}{lllll}\text { Taxation } & \text { Research } & \text { Paper } & \text { Serias }\end{array}$ (http://papers.ssrn.com/sol3/papers.cfm?abstract id=2630943).

Kuźniacki, B. (2016), "Strengthening CFC Rules in a Compatible Way with EU Law under BEPS Action 3 in Light of the European Commission's Proposal - A Critical Evaluation", in Danon, R. (ed.), Base Erosion and Profit Shifting (BEPS): Impact for OECD and EU Tax Policy, Zürich: Schulthess, 2016.

Lang, M. (2010), Cadbury Schweppes' Line of Case Law from the Member States' Perspective, in De la Feria, R. and Vogenauer, S. (eds.), Prohibition of Abuse of Law: A New General Principle of EU?, Oxford: Hart Publishing.

Lang, M. \& Heidenbauer, S. (2008), Wholly Artificial Arrangements, in Hinnekens, L. and Hinnekes, Ph., A Vision of Taxes within and outside European Borders. Festschrift in honor of Prof. Dr. Frans Vanistendael, Alphen aan den Rijn: Kluwer Law International.

Langston, R. (2011), Tolley’s International Tax Planning: 2011-12, London: LexisNexis.

Loureiro, C. M. \& Rodrigues, P. (2013), Portugal - Branch Report: The taxation of foreign passive income for groups of companies, Cahiers de droit fiscal international, Vol. 98a, IFA Congress in Copenhagen.

Markle K. \& Robinson, L. (2012), Tax Haven Use Across International Tax Regimes, June 2012, available online at: http://faculty.tuck.dartmouth.edu/images/uploads/faculty/leslierobinson/MarkleRobinson.pdf. 
McCulloch S. \& Redington, M. (2013), New Zealand Branch Report: The taxation of foreign passive income for groups of companies, Cahiers de droit fiscal international, Vol. 98a, IFA Congress in Copenhagen.

Monsenego, J. (2011), Taxation of Foreign Business Income within the European Internal Market: An Analysis of the Conflict between the Objective of Achievement of the European Internal Market and the Principles of Territoriality and Worldwide Taxation, Doctoral Series IBFD - Academic Council, Vol. 22, Amsterdam: IBFD.

Morawski, L. (2010), Zasady wykładni prawa, Toruń: TNOiK.

Mylonas, A. (2015), The Cyprus Alternative Investment Funds AIF Law, available online at: http://www.mylonaslawfirm.com/en/publications/the-cyprus-alternativeinvestment-funds-aif-law

Neocleous, E. \& Aristotelous, P. (2013), Cyprus: The Cyprus Intellectual Property Rights 'Box', Mondaqu 2013, 5 June 2013, available online at: http://www.mondaq.com/cyprus/x/243428/Trademark/The+Cyprus+Intellectual+Pr operty+Rights+x0027Box.

Orlov, M. (2004), The Concept of Tax Haven: A Legal Analysis, Intertax 2004, Vol. 32, No. 2. O'Shea, T. (2007), Thin Cap GLO and Third-Country Rights: Which Freedom Applies?, Tax Notes International 2007, 27 April 2007.

Piccioto, S. (1992), International Business Taxation. A Study in the Internationalization of Business Regulation, Cambridge: Cambridge University Press.

Piccioto, S. (2014), Transfer Pricing Is Still Dead: From Independent Entity Back to The Unitary Principle, Tax Notes International: News Stories, 6 January 2014.

Pizarro-Suárez, J. I. V \& Revilla Martínez, E. (2013), Mexico - Branch Report: The taxation of foreign passive income for groups of companies, Cahiers de droit fiscal international, IFA Congress in Copenhagen.

Rapakko, A. (1989), Base Company Taxation, Deventer: Kluwer Law and Taxation Publishers.

Reimer, E. (2004), Der Ort des Unterlassens. Die ursprungsbezogene Behandlung von Entgelten für Untätigkeit im Internationalen Steuerrecht, Münchener Universitätsschriften, Reihe der Juristischen Fakultät. 
Reimer, E. (2014), Permanent Establishment in the OECD Model Tax Convention, in Reimer, E., Schmid, S., Orell, M., Permanent Establishments: A Domestic Taxation, Bilateral Tax Treaty, and OECD Perspective, $3^{\text {rd }}$ edition, Alphen aan den Rijn: Wolters Kluwer Law \& Business.

Rienstra, J. G. (2015), United States - Corporate Taxation, Amsterdam: IBFD Tax Research Platform, (Last reviewed: 1 July 2015).

Russo, R. (2009), Fundamentals of international tax planning, Amsterdam: IBFD.

Rust, A. (2011), Business' and 'Business Profits', in Maisto, G. (ed.), The Meaning of "Enterprise", "Business" and "Business Profits" Under Tax Treaties and EU Tax Law, EC and International Tax Law Series, Vol. 7, Amsterdam: IBFD.

Sadiq, K. (2001), Unitary Taxation - The Case for Global Formulary Apportionment, Bulletin for International Fiscal Documentation 2001, No. 7.

Sandell, J. (2012), The Double Irish and the Dutch Sandwich: How Some U.S. Companies Are Flummoxing the Tax Code, Tax Notes International 2012, August 27.

Sandler, D. (1998), Tax treaties and controlled foreign company legislation: pushing the boundaries, the Hague: Kluwer Law International.

Saydé, A. (2014), Abuse of EU Law and Regulation of the Internal Market, Oxford: Hart Publishing.

Schön, W. (2008), Abuse of Rights and European Tax Law, in Avery Jones, J., Harris, P. and Oliver D. (eds.), Comparative perspectives on revenue law: essays in honour of John Tiley, Cambridge: Cambridge University Press.

Slaats, s. \& Worndl, B. (2013), Canada - Branch Report: The taxation of foreign passive income for groups of companies, Cahiers de droit fiscal international, Vol. 98a, IFA Congress in Copenhagen.

Smit, D. (2012), EU freedoms, non EU-countries and Company Taxation, EUCOTAX Series on European Taxation, Alphen aan den Rijn: Wolters Kluwer Law \& Business.

Smit, D. S. (2014), Substance Requirements for Entities Located in a Harmful Tax Jurisdiction under CFC Rules and the EU Freedom of Establishment, Derivatives \& Financial Instruments 2014, No.11-12. 
Strasser, K. A. \& Blumberg, P. (2011), Legal Form and Economic Substance of Enterprise Groups: Implications for Legal Policy, Accounting, Economics, and Law 2011, Vol. 1, No. 1, available online at: http://www.degruyter.com/view/j/ael.2011.1.1/ael.2011.1.1.1000/ael.2011.1.1.1000 . $\mathrm{xml2152-2820}$

Svensen, Ch. (2013), Norway - Branch Report: The taxation of foreign passive income for groups of companies, Cahiers de droit fiscal international, Vol. 98a, IFA Congress in Copenhagen.

Taliotis, A. (2015), Cyprus - Corporate Taxation, Amsterdam: IBFD Tax Reasearch Platform, (Last Reviewed: 1 June 2015).

Templemann, L. (1997), Tackling Tax Avoidance, in Shipwright, A. (ed.), Tax Avoidance and The Law. Sham, Fraud or Mitigation?, Oxford: Key Haven Publications.

Thill, P-S., \& Mihac, E. (1999), French CFC Regime Examined, Tax Notes International 1999, 3 March 1999.

Thömmes, O. \& Nakhai. K. (2005), New Case Law on Anti-Abuse Provisions in Germany, Intertax 2005, Vol. 33, No. 2.

Thuronyi, V. (2003), Comparative Tax Law, the Hague: Kluwer Law International, 2003.

Tickle, D. (2013), South Africa - Branch Report: The taxation of foreign passive income for groups of companies, Cahiers de droit fiscal international, Vol. 98a, IFA Congress in Copenhagen.

Ting, A. (2014), Old wine in a new bottle: Ireland's revised definition of corporate residence and the war on BEPS, British Tax Review 2014, No. 3.

Ting, A. (2015), The Politics of BEPS - Apple's International Tax Structure and the US Attitude towards BEPS, Bulletin for International Taxation, No. 6-7.

Truijens, R. G. N (2014), Curaçao-Corporate Taxation, Amsterdam: IBFD Tax Research Platform, (Last Reviewed: 1 April 2014).

Torregiani, C. C. (2015), Malta - Corporate Taxation, Amsterdam: IBFD Tax Research Platform, (Last Reviewed: 30 April 2015).

Umar, D (2015), Singapore-Corporate Taxation, IBFD Tax Research Platform (Last Reviewed: 1 January 2015). 
Umar, N. (2015a), Indonesia-Corporate Taxation, Amsterdam: IBFD Tax Research Platform (Last Reviewed: 1 February 2015).

Valta, M. (2013), International Tax Law between efficiency, equity and development aid, Presenation of the PhD study awarded by Mitchell B. Carroll Prize at 67th IFA Congress Congress in Copenhagen in 2013, (Congress Documents - 2013).

Vanistendael, F. (1997), Judicial Interpretation and the Role of Anti-abuse Provisions in Tax Law, in Cooper, G. S., (ed.), Tax Avoidance and the Rule of Law, Amsterdam: IBFD.

Vanistendael, F. (2003), Bosal?!, EC Tax Review 2003, No. 4.

Van Weeghel, S. \& Emmerink, F. (2013), Global Developments and Trends in International Anti-Avoidance, Bulletin for International Taxation 2013, No. 8.

Vogel, K. (2005), "State of Residence" may as well be "State of Source" - There is no Contradiction, Bulletin - Tax Treaty Monitor 2005, No. 10.

Warner, Ph. J. \& Schmitz, M. (2004), Luxembourg in International Tax Planning, $2^{\text {nd }}$ revised edition, Amsterdam: IBFD.

Weber, D. (2005), Tax Avoidance and the EC Treaty Freedoms A Study of the Limitations under European Law to the Prevention of Tax Avoidance, Eucotax Series on European Taxation, Vol. 11, the Hague: Kluwer Law International.

Weber, D. (2013), “Abuse of Law in European Tax Law: An Overview and Some Recent Trends in the Direct and Indirect Tax Case Law of the ECJ - Part 1", European Taxation 2013, No.6.

Zalasiński, A. (2009), The Limits of the EC Concept of "Direct Tax Restrictions on Free Movement Rights", the Principles of Equality and Ability to Pay, and the Interstate Fiscal Equity, Intertax 2009, Vol. 37, No. 5.

Zalewski, M. T. (1998), Obejście ustawy podatkowej, Przegląd Podatkowy 1998, No. 7.

Zarb, A. \& Portelli, P. (2015), Malta-Individual Taxation, Amsterdam: IBFD Tax Research Platform, (Last Reviewed: 27 August 2015).

Zimmer, F. (2002), General Report: Form and Substance in Tax Law, Cahiers de droit fiscal international, Vol. 87a, IFA Congress in Oslo. 
Zweigert, K., Kötz, (1998), An Introduction to Comparative Law, Third Edition, Oxford: Clarendon Press, 1998.

\section{Case law and administrative decisions}

\section{International}

\section{EFTA Court}

E-3/13 and E-20/13

Joined cases, Fred. Olsen and Others and Petter Olsen and Others $v$ the Norwegian State, represented by the Central Tax Office for Large Enterprises and the Directorate of Taxes, EFTA Ct. Report 2014-1. p. 402, 9 July 2014.

\section{CJEU: Court of Justice of the European Union}

Srl CILFIT and Lanificio di Gavardo SpA v Ministry of Health, ECR 1982, p. I-03415, 6 October 1982.

C-79/85 D. H. M. Segers v Bestuur van de Bedrijfsvereniging voor Bank- en Verzekeringswezen, Groothandel en Vrije Beroepen, ECR 1986, p. I- 02375, 10 July 1986.

C-60/90

Polysar Investments Netherlands $v$ Inspecteur der Invoerrechten en Accijnzen, ECR 1991, p. I-03111, 20 June 1991. 
C-333/91

C-80/94

C-283/94, C-291/94 and C-292/94

C-80/95

C-264/96

C-212/97

C-375/98

C-142/99

C-110/99

C-136/00

C-208/00
Sofitam SA (anciennement Satam SA) v. Ministre chargé du Budget, ECR 1993, p. I-3513, 22 June 1993.

G. H. E. J. Wielockx v Inspecteur der Directe Belastingen, ECR 1995, p. I-2493, 11 August 1995.

Denkavit Internationaal and Others v Bundesamt für Finanz, ECR 1996, p. I-05063, 17 October 1996.

Harnas \& Helm CV v Staatssecretaris van Financiën, ECR 1997, p. I-00745, 6 February 1997.

Imperial Chemical Industries plc (ICI) $v$ Kenneth Hall Colmer (Her Majesty's Inspector of Taxes), ECR 1998, p. I-4695, 16 July 1998.

Centros Ltd v Erhvervs- og Selskabsstyrelsen, ECR 1999, p. I-01459, 9 March 1999.

Ministério Público and Fazenda Pública v Epson Europe BV, ECR 2000, p. I-04243, 8 June 2000.

Floridienne SA and Berginvest SA v Belgian State, ECR 2000, p. I-9567, 14 November 2000.

Emsland-Stärke GmbH v Hauptzollamt HamburgJonas, ECR 2000, p. I-11569, 14 December 2000.

Rolf Dieter Danner, ECR 2002, p. I-08147, 3 October 2002.

Überseering $B V \vee$ Nordic Construction Company Baumanagement GmbH (NCC), ECR 2002, p. I09919, 5 November 2002. 
C-324/00Lankhorst-Hohorst GmbH v Finanzamt Steinfurt, ECR 2002, p. I-11779, 12 December 2002.

C-422/01

Försäkringsaktiebolaget Skandia (publ) and Ola

Ramstedt v Riksskatteverket,, ECR 2003, p. I-06817,

26 June 2003.

C-167/01

Kamer van Koophandel en Fabrieken voor Amsterdam v Inspire Art Ltd, ECR 2003, p. I-10155, 30 September 2003.

C-9/02

Hughes de Lasteyrie du Saillant $v$ Ministère de l'Économie, des Finances et de l'Industrie, ECR 2004, p. I-2409, 11 March 2004.

C-77/01

Empresa de Desenvolvimento Mineiro, SA v. Fazenda Publica, ECR 2004, p. I-4295, 29 April 2004.

C-446/03

Marks \& Spencer plc v David Halsey (Her Majesty's Inspector of Taxes, ECR 2005, p. I-1083, 13 December 2005.

C-222/04 Ministero dell'Economia e delle Finanze v Cassa di Risparmio di Firenze SpA, Fondazione Cassa di Risparmio di San Miniato and Cassa di Risparmio di San Miniato SpA, ECR 2006, ECR 2006, p. I-289, 10 January 2006.

C-255/02

Halifax plc, Leeds Permanent Development Services Ltd and County Wide Property Investments Ltd $v$ Commissioners of Customs \& Excise, ECR 2006, p. I-01609, 21 February 2006. 
C-341/04

C-196/04

C-446/04

C-524/04

C-157/05

C-425/06

C-27/07

C-201/05

Eurofood IFSC Ltd, ECR 2006, p. I-03813, 2 May 2006.

Cadbury Schweppes plc and Cadbury Schweppes Overseas Ltd v Commissioners of Inland Revenue, ECR 2006, p. I-07995,12 September 2006.

Test Claimants in the FII Group Litigation $v$ Commissioners of Inland Revenue, ECR 2006, p. I11753,12 December 2006.

Test Claimants in the Thin Cap Group Litigation v Commissioners of Inland Revenue, ECR 2007, p. I02107, 13 March 2007.

Winfried L. Holböck $v$ Finanzamt Salzburg-Land, ECR 2007, p. I-04051, 24 May 2007.

Ministero dell'Economia e delle Finanze $v$ Part Service Srl, ECR 2008, p. I-00897, 21 February 2008.

Banque Fédérative du Crédit Mutuel v Ministre de l'Économie, des Finances et de l'Industrie, ECR 2008, p. I-02067, 3 April 2008.

The Test Claimants in the CFC and Dividend Group Litigation v Commissioners of Inland Revenue, ECR 2008, p. I- 02875, 23 April 2008. 
C-284/06

C-247/08

C-182/08

C-439/07 and C-499/07

C-303/07

C-311/08

C-310/09

C-126/10

C-35/11
Finanzamt Hamburg-Am Tierpark v Burda GmbH, ECR 2008, p. I-04571, 26 June 2008.

Gaz de France - Berliner Investissement SA v Bundeszentralamt für Steuern, ECR 2009, p. I09225, 1 October 2009.

Glaxo Wellcome GmbH \& Co. KG v Finanzamt München II, ECR 2009, p. I-8591, 17 September 2009.

Belgische Staat $v$ KBC Bank NV and Beleggen, Risicokapitaal, Beheer NV v Belgische Staat, joined cases, ECR 2009, p. I-04409, 4 June 2009.

Proceedings brought by Aberdeen Property Fininvest Alpha Oy, ECR 2009, p. I-5145, 18 June 2009.

Société de Gestion Industrielle (SGI) v Belgian State, ECR 2010, p. I-00487, 21 January 2010.

Ministre du Budget, des Comptes publics et de la Fonction publique $v$ Accor SA, ECR 2011, p. I08115, 15 September 2011.

Foggia - Sociedade Gestora de Participações Sociais SA v Secretário de Estado dos Assuntos Fiscais, ECR 2011, p. I-10923, 10 November 2011.

Test Claimants in the FII Group Litigation $v$ Commissioners of Inland Revenue and The Commissioners for Her Majesty's Revenue \& 
$\begin{array}{lll}\text { Customs, } & \text { electronic } & \text { ECR }\end{array}$

(ECLI:EU:C:2012:707), 13 November 2012.

C-168/11

C-282/12

C-190/12

C-39/13, C-40/13, and C-41/13

\section{AG: Advocate Generals (opinions)}

AG Opinion Open Skies

AG opinion Halifax et al.
Manfred Beker and Christa Beker v Finanzamt Heilbronn, electronic $\quad$ ECR 2013 (ECLI:EU:C:2013:117), 28 February 2013.

Itelcar - Automóveis de Aluguer Lda v Fazenda $\begin{array}{lll}\text { Pública, } & \text { electronic } & \text { ECR }\end{array}$ (ECLI:EU:C:2013:629), 3 October 2013.

Emerging Markets Series of DFA Investment Trust Company v Dyrektor Izby Skarbowej w Bydgoszczy, ECR, not yet published (ECLI:EU:C:2014:249), 10 April 2014.

Inspecteur van de Belastingdienst/Noord/kantoor Groningen v SCA Group Holding $B V, X A G$ and Others $v$ Inspecteur van de Belastingdienst Amsterdam and Inspecteur van de Belastingdienst Holland-Noord/kantoor Zaandam $v \quad M S A$ International Holdings $B V$ and MSA Nederland $B V$, not yet published (ECLI:EU:C:2014:1758), 12 June 2014

Opinion of Advocate General Tizzano, case C466/98, Commission of the European Communities $v$ United Kingdom of Great Britain and Northern Ireland, ECR 2002, p. I-9427, 31 January 2002.

Opinion of Advocate General Maduro, case C255/02, Halifax plc, Leeds Permanent 
Development Services Ltd, County Wide Property Investments Ltd v Commissioners of Customs and Excise, ECR 2006, p. I-01609, 7 April 2005.

AG Jacobs Cassa di Risparmio di Opinion of Advocate General Jacobs, case CFirenze 222/04, Ministero dell'Economia e delle Finanze $v$ Cassa di Risparmio di Firenze and others, (2006) ECR I-289, 27 October 2005.

AG Opinion Cadbury Schweppes Opinion of Advocate General Léger, case C196/04, in Cadbury Schweppes plc and Cadbury Schweppes Overseas Ltd $v$ Commissioners of Inland Revenue, ECR 2006, p. I-7997, 2 May 2006.

\section{New Zealand}

\section{Supreme Court: Privy Council}

Privy Council's judgment of 21 July CIR (NZ) $v$ Challenge Corporation Ltd case, 1986 [1987] AC 155

\section{UK}

\section{Supreme Court: House of Lords}

Ensign Tankers [1992]1 AC 655

Ensign Tankers (Leasing Ltd) v Stokes case, [1992]1 AC 655, judgment of House of Lords, 14 January 1992. 


\section{Poland}

SAC: Supreme Administrative Court (Naczelny Sąd Administracyjny)

SAC's judgment of 24 July 2015

SAC's resolution of 16 January 2012
Case No. II FSK 1455/13, Supreme Administrative Court.

Case No. II FPS 1/11, seven judges of the Supreme Administrative Court.

DTCh: Director of Tax Chamber (Dyrektor Izby Skarbowej) - advance tax rulings

DTCh in Poznan of 21 October 2008 Ref. No. 415-471/08-3/JK, Director of Tax Chamber in Poznań.

DTCh in Warsaw of 19 November Ref. No. IPPB2/415-549/09-2/AK, Director of Tax 2009 Chamber in Warsaw.

DTCh in Warsaw of 27 November 2009

DTCh in Warsaw of 3 February 2011

DTCh in Poznan of 3 March 2011
Ref. No. IPPB2/415-561/09-2/MS, Director of Tax Chamber in Warsaw.

Ref. No. IPPB2/415-968/10-2/AS, Director of Tax Chamber in Warsaw.

Ref. No. ILPB2/415-1409/10-2/JK, Director of Tax Chamber in Poznań.

Ref. No. IBPBI/1/415-102/11/BK, Director of the 
Tax Chamber in Katowice

DTCh in Poznań of 2 December 2011 Ref. No. ILPB2/415-981/11-4/JK, Director of the Tax Chamber in Poznań.

DTCh in Katowice of 10 November 2011

Ref. No. IBPBI/2/423-1001/11/MO, Director of Tax Chamber in Katowice.

DTCh in Poznań of 21 December Ref. No. ILPB4/423-354/11-2/MC, Director of Tax 2011 Chamber in Poznań.

DTCh in Warsaw of 24 February 2012

Ref. No. IPPB5/423-1125/11-4/AJ, Director of Tax Chamber in Warsaw.

DTCh in Warsaw of 17 July 2012

Ref. No. IPPB1/415-469/12-3/KS, Director of the Tax Chamber in Warsaw.

DTCh in Bydgoszcz of 30 October Ref. No. ITPB1/415-936/12/HD, Director of the Tax 2012 Chamber in Bydgoszcz.

DTCh in Poznań of 27 December Ref. No. ILPB2/415-912/12-2/WM, Director of Tax 2012 Chamber in Poznań.

DTCh in Warsaw of 21 January 2013 Ref. No. IPPB2/415-1035/12-2/EL, Director of Tax Chamber in Warsaw.

DTCh in Poznań of 10 May 2013 Ref. No. ILPB1/415-175/13-4/AG, Director of Tax Chamber in Poznań.

DTCh in Warsaw of 4 July 2013

Ref. No. IPPB2/415-269/13-4/EL, Director of Tax Chamber in Warsaw.

DTCh in Poznań of 18 July 2013 Ref. No. ILPB1/415-477/13-2/IM, Director of Tax 
Chamber in Poznań.

DTCh in Poznań of 14 August 2013

DTCh in Poznań of 29 October 2013

DTCh in Łódź of 19 December 2013

DTCh in Warsaw of 29 March 2016
Ref. No. IBPBII/1/415-447/13/HK, Director of Tax Chamber in Poznań.

Ref. No. ILPB1/415-870/13-2/TW, Director of Tax Chamber in Poznań.

Ref. No. IPTPB1/415-623/13-3/MD, Director of Tax Chamber in Łódź.

Ref. No. IPPB1/4511-18/16-4/MT, Director of Tax Chamber in Warsaw.

\section{Sources of law}

\section{Bilateral tax treaties}

Poland- Cyprus 1992

Agreement between the Government of the Republic of Poland and the Government of the Republic of Cyprus for the Avoidance of Double Taxation with respect to Taxes on Income and on Capital, signed 4 June 1992.

Poland-Slovakia 1994

Agreement between the Republic of Poland and the Slovak Republic for the Avoidance of Double Taxation with respect to Taxes on Income and on Capital, signed 18 August 1994.

Poland-Luxembourg 1995

Convention between the Grand Duchy of Luxembourg and the Republic of Poland for the Avoidance of Double Taxation and the Prevention of Fiscal Evasion with respect to Taxes on Income and on Capital, signed 14 June 1995.

Poland-Netherlands 2002

Convention between the Kingdom of the Netherlands and the Republic of Poland for the Avoidance of Double Taxation and the Prevention of Fiscal Evasion with respect to Taxes on Income, signed 13 february 2002.

Cyprus-UAE 2011

Agreement between the Government of the Republic of Cyprus and the Government of the United Arab Emirates for the Avoidance of Double 
Taxation and the Prevention of Fiscal Evasion with respect to Taxes on Income, signed 27 February 2011.

\section{EU Treaties}

TFEU

Cadbury Schweppes plc and Cadbury Schweppes Overseas Ltd v Commissioners of Inland Revenue, ECR 2006, p. I-07995,12 September 2006.

TEU

Treaty on European Union, signed at Maastricht on 7 February 1992 (entred into force on 1 November 1993), Official Journal C 326, 26/10/2012, pp. 13390 , consolidated version.

\section{EU Directives}

Directive on mutual assistance Council Directive 77/799/EEC of 19 December $(77 / 799)$ 1977 concerning mutual assistance by the competent authorities of the Member States in the field of direct taxation and taxation of insurance premiums, Official Journal L 336, 27/12/1977, pp. $15-20$

Interest \& Royalties Directive

Council Directive 2003/49/EC of 3 June 2003 on a $(2003 / 49)$ common system of taxation applicable to interest and royalty payments made between associated companies of different Member States, Official Journal L 157, 26/06/2003, pp. 49-54.

VAT Directive

Council Directive 2006/112/EC on the common $(2006 / 112)$ system of value added tax as regards the rules on invoicing, Official Journal L 347, 11/12/2006, pp. $1-118$. 
Directive on administrative Council Directive 2011/16/EU of 15 February 2011 cooperation in taxation $(2011 / 16)$ on Administrative Cooperation in the Field of Taxation and Repealing Directive 77/799/EEC, Official Journal L 64, 11/3/2011, pp. 1-12.

Parent-Subsidiary Directive $(2011 / 96)$

Anti-Tax Avoidance Directive
Council Directive 2011/96/EU of 30 November 2011 on the common system of taxation applicable in the case of parent companies and subsidiaries of different Member States, Official Journal L 345, 29/12/ 2011, pp. 8-16.

Council Directive (EU) 2016/1164 of 12 July 2016 laying down rules against tax avoidance practices that directly affect the functioning of the internal market, Official Journal L 193/1, 19/07/ 2016, pp. $1-14$.

\section{Communication, proposals, resolutions, reports and others}

$\operatorname{COM}(2007) 785$ final
Communication from the Commission to the Council, the European Parliament and the European Economic and Social Committee - The Application of Anti-abuse Measures in the Area of Direct Taxation - within the EU and in relation to Third Countries, Brussels, 10 December 2007.

EU Council Resolution of 8 June 2010 Council of the European Union's Resolution of 8 June 2010 on coordination of the Controlled Foreign Corporation (CFC) and thin capitalisation rules within the European Union, Official Journal,16/06/2010, C 156/01, pp. 1-2. 
$\operatorname{COM}(2012) 351$ final

$\operatorname{COM}(2012) 722$ final

$\operatorname{COM}(2015) 302$ final

$\operatorname{COM}(2016) 26$ final
Communication from the Commission to the European Parliament and the Council on concrete ways to reinforce the fight against tax fraud and tax evasion including in relation to third countries, Brussels, 26 June 2012.

Communication from the Commission to the European Parliament and the Council on an Action Plan to strengthen the fight against tax fraud and tax evasion, Brussels, 6 December 2012.

Communication from the Commission to the European Parliament and the Council on an Fair and Efficient Corporate Tax System in the European Union: 5 Key Areas for Action, Brussels, 17 June2015.

Proposal for a Council Directive laying down rules against tax avoidance practices that directly affect the functioning of the internal market, Brussels, 28 January, 2016.

\section{Poland}

\section{Statutes}

PITA

Personal Income Tax Act of 26 July 1991 (Ustawa $z$ dnia 26 lipca 1991 r. o podatku dochodowym od osób fizycznych), Journal of Laws of 1991, No. 80, item 350 . 
z dnia 15 lutego 1992 r. o podatku dochodowym od osób prawnych), Journal of Laws of 1992, No. 21, item 86.

TO

Tax Ordinance Act of 29 August 1997 (Ustawa $z$ dnia 29 sierpnia 1997 r. - Ordynacja podatkowa), Journal of Laws of 1997, No. 137, item 926.

FPC

Fiscal Penal Code of 10 September 1999 (Ustawa z dnia z 10 września 1999 r. Kodeks karny skarbowy), Journal of Laws of 2007, No. 111, item 765, consolidated act.

AFE

Act on Freedom of Establishment of 2 July 2004 (ustawa $z$ dnia 2 lipca 2004 r. o swobodzie działalności gospodarczej), Journal of Laws of 2013, No. 672, the consolidated text.

\section{Regulations}

Ministry of Finance, No. 16, item 197

Ordinance of the Ministry of Finance of 27 March 1995 on general exchange permission (Zarzadzenie Ministra Finansów z dnia 27 marca 1995 r. w sprawie ogólnych zezwoleń dewizowych), Polish Monitor (Monitor Polski), No. 16, item 197.

\section{UK}

\section{Statutes}

TIOPA (2010)

Finance Act 2012, 17 July 2012 (FA 2012), Pt. 4 and Schedule 20, which is a part of and the Taxation (International and Other Provisions) Act 2010, 
(TIOPA).

CTA 2009

Corporation Tax Act 2009 (CTA).

TCGA

Taxation of Chargeable Gains Act 1992, the UK, available online at: http://www.legislation.gov.uk/ukpga/1992/12/conte nts/enacted.

\section{OECD: Reports and other documents}

OECD (1986)

OECD (1986a)

OECD (1987)

OECD (1998)

OECD (2001)
OECD, Double Taxation Conventions and the use of base companies, Paris: OECD, 1986.

OECD, Double Taxation Conventions and the Use of Conduit Companies, Paris: OECD, 1986.

OECD, "Tax Havens: Measures to Prevent Abusesby Taxpayers", in International Tax Avoidance and Tax Evasion: Four Related Studies, Paris: OECD, 1987.

OECD, Harmful Tax Competition: An Emerging Global Issue, Paris: OECD, 1998.

OECD, The OECD's Project on Harmful Tax Practices: The 2001 Progress Report, Paris: OECD, 2001. 
OECD (2001a)

OECD (2008)

OECD (2010)

OECD (2011)

OECD (2011a)

OECD (2013)

OECD (2013a)

OECD (2014)

OECD (2014a)

OECD (2014b)
OECD, "Corporate Tax Incentives for Foreign Direct Investment", in OECD Tax Policy Studies, Paris: OECD, 2001, No. 4.

OECD, OECD Benchmark Definition of Foreign Direct Investment. Fourth Edition, Paris: OECD, 2008.

OECD, OECD Transfer Pricing Guidelines for Multinational Enterprises and Tax Administrations, Paris: OECD, 2010.

OECD, OECD Guidelines for Multinational Enterprises, 2011 Edition, Paris: OECD, 2011.

OECD/The World Economic Forum, Competitiveness and Private Sector Development: Central Asia 2011: Competitiveness Outlook, Paris: OECD, 2011.

OECD, Addressing Base Erosion and Profit Shifting, Paris: OECD, 2013.

OECD, Action Plan on Base Erosion and Profit Shifting, Paris: OECD, 2013.

OECD, Tax Transparency 2014: Report on Progress, Paris: OECD, 2014.

OECD, Neutralising the Effects of Hybrid Mismatch Arrangements, OECD/G20 Base Erosion and Profit Shifting Project, OECD Publishing, Paris: OECD, 2014.

OECD, OECD/G20 Base Erosion and Profit Shifting Project - Explanatory Statement - 2014 Deliverables, Paris: OECD 2014. 
OECD (2015)

OECD (2015a)

OECD (2015b)
OECD, Designing Effective Controlled Foreign Company Rules, Action 3 -Final Report, Paris: OECD, 5 October 2015.

OECD, Neutralising the Effects of Hybrid Mismatch Arrangements, Action 2 - Final Report, Paris: OECD, 5 October 2015.

Live webcast: Update on BEPS Project, Paris: OECD, 12 February 2015, available online: http://www.oecd.org/ctp/beps-webcasts.htm.

\section{Official documents and hearings}

IRS (2015)

IRS, Abusive Tax Shelters and Transactions, available online

at: http://www.irs.gov/Businesses/Corporations/Abusiv e-Tax-Shelters-and-Transactions.

House of Commons Public Accounts Committee (2013)

House of Commons Public Accounts Committee 19th

Report (November 28, 2012), available at http://

www.publications.parliament.uk/pa/cm201213/cmse lect/cmp ubacc/716/71602.htm.

Ministry of Economy of Poland Departament Strategii i Analiz Ministerstwa (2015) Gospodarki, Inwestycje Bezpośrednie w 2013 roku, March 2015, Warsaw, available online at: http://www.mg.gov.pl/files/upload/8439/Polskie\%20 BIZ\%202013.pdf . 
Ministry of Economy of Poland Departament Analiz i Prognoz Ministerstwa (2013) Gospodarki, Polskie Inwestycje Bezpośrednie w 2011 roku, March, 2013, Warsaw., available online at: http://www.mg.gov.pl/files/upload/8439/Polskie_inw est_bezp_2011.pdf.

Polish Department of

Exchange (1996)

SARS (2005)

TPCA (2015)

US Hearing Report (2013)
Polish Department of Exchange, Polska Polityka Handlu zagranicznego 1995-1996, Warsaw 1996.

SARS, Discussion Paper on Tax Avoidance and Section 103 of the Income Tax Act, 1962 (Act No. 58 of 1962), Law Administration, South African Revenue Service, November 2005. http://www.ftomasek.com/DiscussionPaperGAAR20 051103.pdf.

Transfer Pricing Centre Association in Poland (TPCA), Comments on the Discussion Draft on Interest Deductions and Other Financial Payments (Action 4 of the BEPS Action Plan), Warsaw, 6 February 2015, available online at: http://cct.org.pl/wpcontent/uploads/2015/02/2015_0206_OECDinterest_FINAL.pdf.

Homeland Security and Governmental Affairs Permanent Subcommittee on Investigations, Offshore Profit Shifting and the U.S. Tax CodePart 2 (Apple Inc.) 2013 available at: http://www.hsgac.senate.gov/subcommittees/investi gations/hearings/offshore-profit-shifting-and-the-ustax-code_-part-2. 